CENTRO UNIVERSITÁRIO FEI

ANDRÉ VICTOR DUARTE SILVA

ESTUDO DA ADOÇÃO DE INTERNET OF THINGS NO PLANTIO DE HORTALIÇAS

São Bernardo do Campo

2021 
ANDRÉ VICTOR DUARTE SILVA

\section{ESTUDO DA ADOÇÃO DE INTERNET OF THINGS NO PLANTIO DE HORTALIÇAS}

Dissertação apresentada ao Centro Universitário FEI para obtenção do título de Mestre em Engenharia de Produção. Orientado pela Prof. Dr. Gabriela Scur

São Bernardo do Campo 
Silva, André Victor Duarte. ESTUDO DA ADOÇÃO DE INTERNET OF THINGS NO PLANTIO DE HORTALIÇAS / André Victor Duarte Silva. São Bernardo do Campo, 2021. $110 \mathrm{f}$ : : il.

Dissertação - Centro Universitário FEl. Orientadora: Prof. ${ }^{a}$ Dra. Gabriela Scur Almudi.

1. Internet of Things. 2. IoT. 3. Adoção. 4. Hortaliças. I. Scur Almudi, Gabriela, orient. II. Título.

Elaborada pelo sistema de geração automática de ficha catalográfica da FEI com os dados fornecidos pelo(a) autor(a). 
Título do Trabalho: Estudo da adoção de internet of things no plantio de hortaliças.

Área de Concentração: Produção

Orientador: Profa Dra Gabriela Scur Almudi

Data da realização da defesa: 03/02/2021

\section{ORIGINAL ASSINADA}

\section{Avaliação da Banca Examinadora:}

Corrigir figura 07 e pequenas alterações de forma, conforme anotações feitas pelo aluno.

São Bernardo do Campo, 03 / 02 / 2021.

\section{MEMBROS DA BANCA EXAMINADORA}

Profa Dra Gabriela Scur Almudi

Profa Dra Claudia Aparecida de Mattos

Prof. Dr. Rodrigo Franco Gonçalves
Ass.:

Ass.:

Ass.:

A Banca Julgadora acima-assinada atribuiu ao aluno o seguinte resultado:

APROVADO $\square \quad$ REPROVADO

\section{VERSÃO FINAL DA DISSERTAÇ̃̃O}

APROVO A VERSÃo FINAL DA DISSERTAÇÃO EM QUE FORAM INCLUÍDAS AS RECOMENDAÇÕES DA BANCA EXAMINADORA
Aprovação do Coordenador do Programa de Pós-graduação

Prof. Dr. Rodrigo Magnabosco 


\section{RESUMO}

Dado o cenário de modernização da agricultura e do aumento de estudos sobre a utilização de Internet of Things, houve a necessidade de pesquisa em ambos assuntos. O presente trabalho foca no entendimento das barreiras e habilitadores da adoção de loT no plantío de hortaliças - tipo de cultura que tem sido menos aprofundado na literatura - através de um quadro teórico que agrega construtos de modelos de adoção de tecnologia de caráter individual e organizacional, sintetizando os fatores comportamentais, tecnológicos, organizacionais e ambientais no contexto do produtor agrícola, sustentado pelos modelos TOE (Technology-OrganizationEnvironment) e UTAUT (Unified Theory of Acceptance and Use of Technology). A pesquisa tem natureza qualitativa com utilização de estudo de caso por meio de entrevistas à produtores, especialistas e fornecedores. Os resultados obtido indicam que o tamanho, conhecimento, nível de gestão e poder de investimento do produtor impactam na adoção de Internet of Things.

Palavras Chave: Internet of Things. IoT. Adoção. Hortaliças. 


\begin{abstract}
Given the scenario of modernization of agriculture and the increase in studies on the use of Internet of things, there was a need for research on both subjects. The present work focuses on understanding the barriers and enablers of adoption loT in planting vegetables - type of culture that has been less deepened in the literature through a theoretical framework that aggregates constructs of models of adoption of technology of individual and organizational character, synthesizing the behavioral, technological, organizational and environmental factors in the context of the agricultural producer, supported by the TOE (Technology-Organization-Environment) and UTAUT (Unified Theory of Acceptance and Use of Technology) models. The research is qualitative with a case study by producers, specialists and suppliers. The results inform that the size, knowledge, management level and investment power of the producer impact the adoption of Internet of Things.
\end{abstract}

Keywords: Internet of things. loT. Adoption. Vegetables. 


\section{LISTA DE ILUSTRAÇÕES}

Figura 01 - Evolução das publicações ao longo do tempo...................... 13

Figura 02 - Palavras mais utilizadas em Títulos e Resumos.................. 15

Figura 03 - Coautoria de artigos.................................................. 16

Figura 04 - Processo de Seleção dos Artigos....................................... 17

Quadro 01 - Tecnologias relacionada a Internet of Things................... 20

Quadro 02 - Estados Produtores de Hortaliças.................................... 25

Quadro 03 - Momento da Colheita.................................................. 28

Figura 05 - Cadeia de Abastecimento................................................ 29

Figura 06 - Modelo TRA............................................................ 32

Figura 07 - Modelo TAM............................................................ 32

Figura 08 - Modelo TAM2 .......................................................... 34

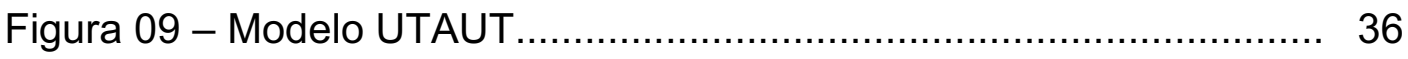

Quadro 04 - Variáveis e Construtos para composição do UTAUT.......... 36

Quadro 05 - Variáveis UTAUT........................................................ 37

Quadro 06 - UTAUT e Internet of Things............................... 39

Figura 10 - Estrutura Modelo TOE.................................................. 42

Quadro 07 - Quadro Teórico......................................................... 46

Figura 11 - Modelo Proposto............................................................ 47

Quadro 08 - Fator Comportamental............................................... 48

Quadro 09 - Proposições............................................................... 51

Quadro 10 - Estudos Similares................................................... 52

Quadro 11 - Produtores Entrevistados............................................. 57

Quadro 12 - Especialistas Entrevistados........................................... 57

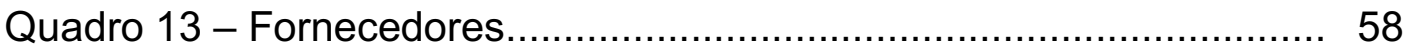

Quadro 14 - Tamanho em Faturamento dos Produtores....................... 58

Quadro 15 - Irrigação e Fertilização do Solo........................................ 62

Quadro 16 - Expectativa de Performance dos Pequenos Produtores..... 63

Quadro 17 - Conhecimento sobre loT............................................... 64

Quadro 18 - Influência Social nos pequenos produtores........................ 65 
Quadro 19 - Influência Social no grandes produtores............................. 65

Quadro 20 - Monitoramento Offline...................................................... 67

Quadro 21 - Evidências sobre Disponibilidade ................................... 70

Quadro 22 - Evidências Estrutura Organizacional................................. 71

Quadro 23 - Diferença entre pequenos e grande produtores................. 72

Quadro 24 - Atravessadores............................................................... 73

Quadro 25 - Grandes Varejistas.................................................... 74

Quadro 26 - Pressão Competitiva...................................................... 75

Quadro 27 - Rastreabilidade...................................................... 76

Quadro 28 - Pandemia coronavírus e a lei de rastreabilidade................ 76

Quadro 29 - Grandes Produtores e a Lei de Rastreabilidade.................. 77

Quadro 30 - Apoio Governamental................................................... 77

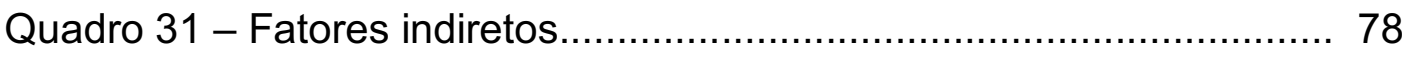

Quadro 32 - Principais apontamentos - Expectativa de Performance.... 79

Quadro 33 - Principais apontamentos - Expectativa de Esforço............. 80

Quadro 34 - Principais apontamentos - Influência Social....................... 82

Quadro 35 - Principais apontamentos - Condições Facilitadoras.......... 83

Quadro 36 - Resultados - Fator Comportamental................................. 84

Quadro 37 - Principais apontamentos - Custo.................................... 86

Quadro 38 - Principais apontamentos - Disponibilidade....................... 87

Quadro 39 - Resultados - Fator Tecnológico....................................... 88

Quadro 40 - Principais apontamentos - Tamanho e Estrutura............... 89

Quadro 41 - Resultados - Fator Organizacional.................................... 90

Quadro 42 - Principais apontamentos - Pressão Competitiva............... 91

Quadro 43 - Principais apontamentos - Apoio do Governo e

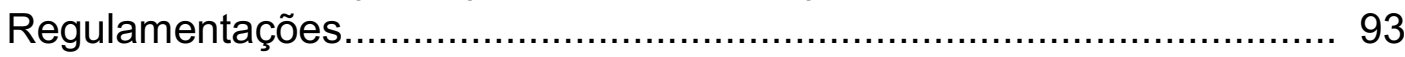

Quadro 44 - Resultados - Fator Ambiental.......................................... 94

Quadro 45 - Revisão Quadro Teórico................................................... 94 


\section{LISTA DE TABELAS}

Tabela 01 - Quantidade de publicações por periódico............................ 13

Tabela 02 - Categorias de Temas.................................................... 18

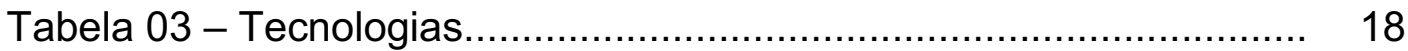

Tabela 04 - Quantidade Comercializada de Hortaliças......................... 25

Tabela 05 - Valor monetário da comercialização de hortaliças.............. 26

Tabela 06 - Especificações das hortaliças........................................... 27

Tabela 07 - Escolaridade .............................................................. 59

Tabela 08 - Utilização de Tecnologias de Sensoriamento..................... 60

Tabela 09 - Média de Idade dos Produtores....................................... 60

Tabela 10 - Principais Clientes...................................................... 60 
1 INTRODUÇÃO

2 FUNDAMENTAÇÃO TEÓRICA............................................... 12

$2.1 \quad$ INTERNET OF THINGS ..................................................... 19

2.2 INTERNET OF THINGS E AGRICULTURA.............................. 21

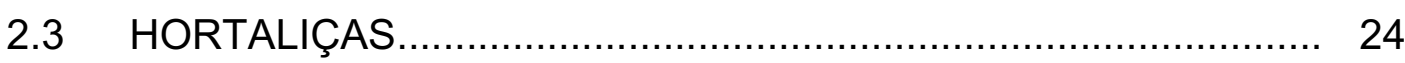

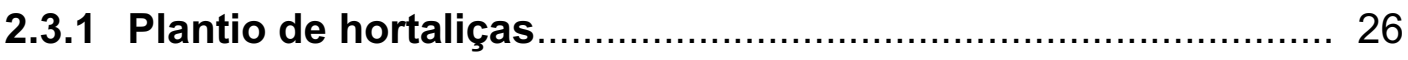

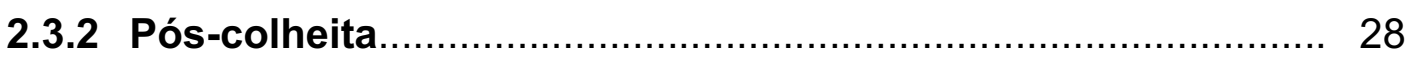

2.4 MODELOS DE ADOÇÃO DE TECNOLOGIA .............................. 30

2.4.1 Modelos individuais ............................................................. 31

2.4.1.1 TRA

2.4.1.2 TAM

2.4.1.3 TAM2

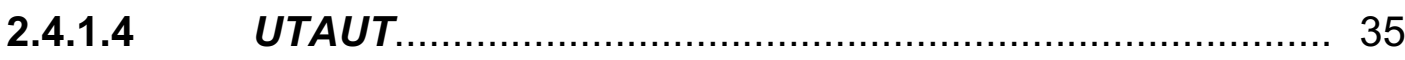

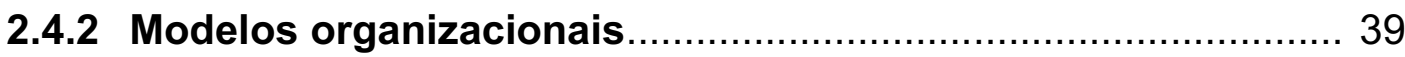

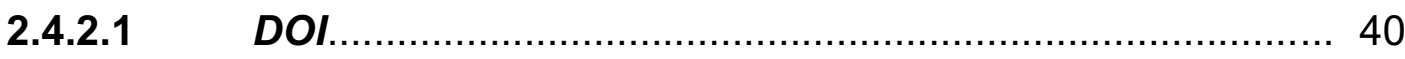

2.4.2.2 TOE

3 QUADRO TEÓRICO

3.1 FATOR COMPORTAMENTAL............................................ 48

3.2 FATOR TECNOLÓGICO............................................................ 49

3.3 FATOR ORGANIZACIONAL ................................................. 50

$3.4 \quad$ FATOR AMBIENTAL........................................................ 50

3.5 PROPOSIÇÕES................................................................... 51

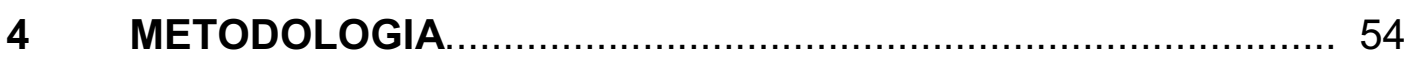

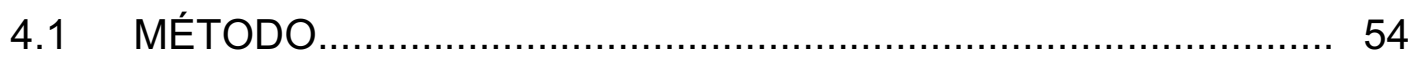

4.2 INSTRUMENTO DA PESQUISA ............................................ 56

4.3 PRODUTORES , ESPECIALISTAS E FORNECEDORES.......... 56

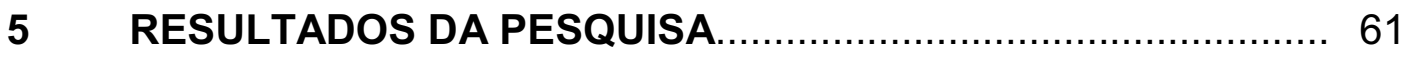


5.1 RESULTADOS FATOR COMPORTAMENTAL ...................... 61

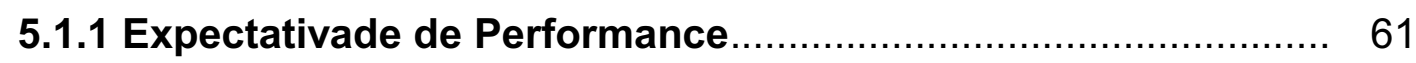

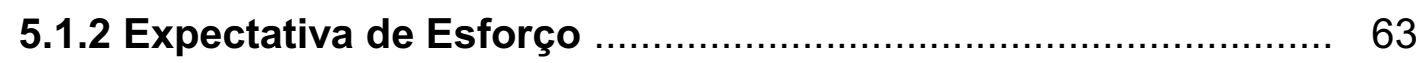

5.1 .3 Influência Social................................................... 64

5.1.4 Condições Facilitadoras ........................................... 66

5.2 RESULTADOS FATOR TECNOLÓGICO............................. 67

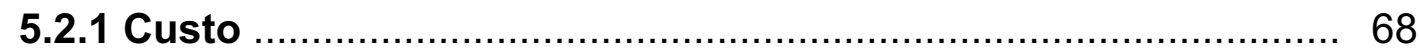

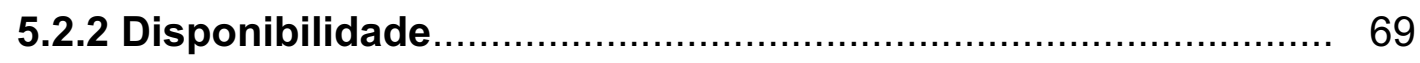

5.3 RESULTADOS FATOR ORGANIZACIONAL ........................ 70

5.4 RESULTADOS FATOR AMBIENTAL .............................. 73

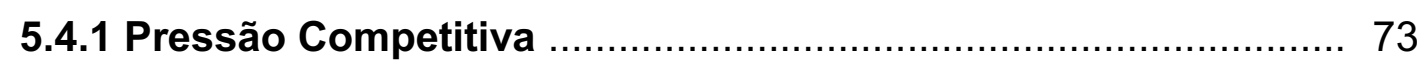

5.4.2 Apoio do Governo e Regulamentações ............................ 75

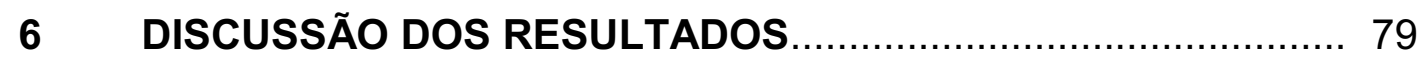

6.1 DISCUSSÃO FATOR COMPORTAMENTAL ......................... 79

6.2 DISCUSSÃO FATOR TECNOLÓGICO................................. 85

6.3 DISCUSSÃO FATOR ORGANIZACIONAL ........................... 88

6.4 DISCUSSÃO FATOR AMBIENTAL ................................ 91

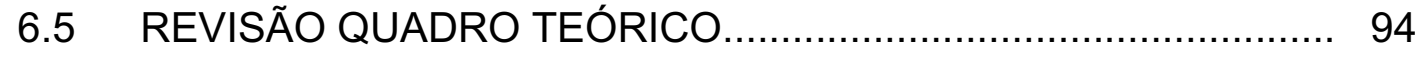

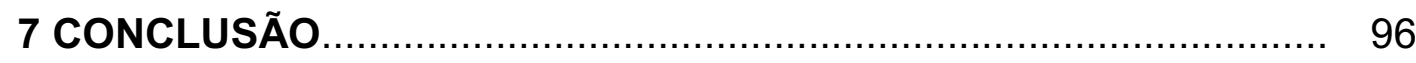

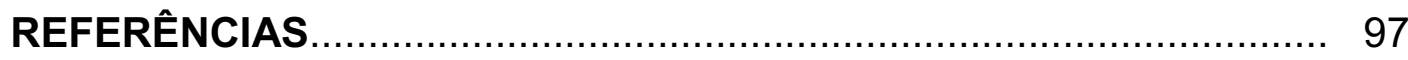

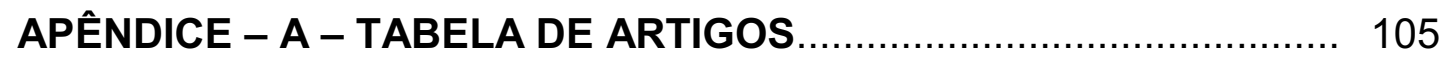

APÊNCIDE - B - PROTOCOLO DE PESQUISA - PRODUTORES....... 107

APÊNCIDE - C - PROTOCOLO DE PESQUISA - ESPECIALISTAS E

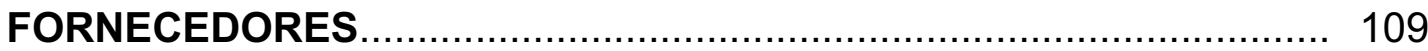




\section{INTRODUÇÃO}

A agricultura passa por uma modernização, em que os agricultores necessitam de informações e monitoramento para tomada de decisão sobre o plantio. Desta maneira, exige-se sistemas com automatização avançada e comunicação em rede (MONHANRAJ; ASHOKUMAR; NAREN, 2016).

Com o crescimento da população mundial e a necessidade da produção de alimentos, a agricultura baseada em Internet of Things está sendo utilizada para o aumento da eficiência do plantio, através do monitoramento do solo, das culturas, dos maquinários, do armazenamento, do uso de fertilizantes e do consumo de energia (AHMED; DE, 2018).

Segundo Alhogail (2018), o termo Internet of Things (IOT) ganhou maior importância nos últimos anos, pois tem como objetivo interligar pessoas, tecnologias e serviços inteligentes. A agricultura baseada em Internet of Things permite o uso efetivo da terra, qualidade e segurança na produção agrícola. O sistema pode ser projetado para altos padrões de qualidade e valor comercial, tornando o mercado de produtos agrícolas mais dinâmico e competitivo (GONZALES-AMARILLO et al., 2018). Neste sentido, Etriya et al. (2018) afirmam que a inovação no segmento agrícola é importante pois aprimora os produtos e impulsiona as receitas dos agricultores.

Mesmo neste cenário de modernização da agricultura, os produtores mantêmse especialistas nos processos relacionados ao plantio, sem experiência nas aplicações de Internet of Things, explicitando a necessidade destes usuários participarem da elaboração, integração e uso das interfaces tecnológicas (FERRÁNDEZ-PASTOR et al., 2018). No mesmo contexto da aceitação e adoção de computadores na década de 80 que originaram os modelos de aceitação e adoção de tecnologia, verifica-se a necessidade de estudos para adoção de internet of things em diferentes contextos e grupos de usuários (JANG; YU, 2017).

Os fatores que podem estimular ou dificultar a adoção de internet of things na agricultura são custo, segurança, privacidade e risco na utilização das tecnologias, sendo estes os fatores que tangenciam uma abordagem tecnológica-organizacionalambiental (MEKALA; VISWANATHAN, 2017), além do entendimento e interface do usuário que tangencia o ponto de vista comportamental (FERRÁNDEZ-PASTOR et al., 2018). 
Outro ponto é a necessidade de melhoria na utilização de Internet of Things nas produções agrícolas em fatores de interoperabilidade, robustez e custo de implementação dos sistemas, sendo estes os fatores que dificultam ou auxiliam na adoção de loT (RAY, 2017; FERRÁNDEZ-PASTOR et al. 2018). Carcary et al. (2018) propõem como pesquisa futura entender quais habilidades são necessárias no ambiente individual e organizacional para adotar e utilizar Internet of Thing. Por fim, AlHogail (2018) verifica que é necessária a especificação de novos domínios da aplicação de internet of things.

O presente trabalho tem como objetivo analisar os fatores tecnológicos, organizacionais, ambientais e comportamentais que impactam a adoção de Internet of Things na produção de hortaliças, com base nos modelos de adoção e aceitação de tecnologia TOE (Technology-Organization-Environment) e UTAUT (Unified Theory of Acceptance and Use of Technology). A questão de pesquisa é: Como os produtores de hortaliças são impactados por fatores tecnológicos, organizacionais, ambientais e comportamentais no processo de adoção de internet of things?

Vislumbra-se alcançar os seguintes objetivos específicos:

- Discutir os fatores que impactam na adoção de internet of things no plantio de hortaliças sob o ponto de vista tecnológico;

- Discutir os fatores que impactam na adoção de internet of things no plantio de hortaliças sob o ponto de vista organizacional;

- Discutir os fatores que impactam na adoção de internet of things no plantio de hortaliças sob o ponto de vista ambiental;

- Discutir os fatores que impactam na adoção de internet of things no plantio de hortaliças sob o ponto de vista comportamental; 


\section{FUNDAMENTAÇÃO TEÓRICA}

A revisão da literatura é necessária para adquirir uma compreensão sobre um assunto, do que já fora estudado anteriormente, quais métodos foram utilizados e seus principais gaps (HART, 2009). Para Collins e Fauser (2005) a revisão da literatura avalia e sintetiza evidências de pesquisa baseada em um protocolo que proporciona uma valiosa fonte de informação, gerando uma análise válida com estudos originais, sem viés e transparentes. Um dos métodos de revisão da literatura é a bibliometria, definida por Lopes (2018) como um método que se baseia na busca de artigos por meio de bases de dados.

Para a realização da bibliometria utilizou-se a base de dados da Web of Science, no dia 24 de maio de 2019, com os termos "Internet of Things" e "Agriculture" e suas variações, resultando na busca: ("Internet of Things" or "Internet of Thing" or "IoT") AND ("Agriculture" or "Farm"). Recorreu-se aos termos "Agriculture" or "Farm" pois o termo "Vegetables" (tradução de "Hortaliças") não responde com amostra significativa de artigos (30 artigos), além de a maioria dos artigos apresentarem foco em outras áreas de estudo, como armazenamento e supply chain. $O$ baixo número de artigos relacionado a hortaliças explicita a necessidade de mais aprofundamento de pesquisa sobre este tipo de plantio.

$\mathrm{Na}$ busca realizada, a base de dados retornou 728 publicações, que se reduziu para 182 com a exclusão de artigos publicados apenas em congresso. Então, 182 são apenas artigos publicados em revistas científicas.

Na Figura 01 se vê uma intensificação nos últimos anos das pesquisas sobre Internet Of Things na agricultura, passando de uma média de 7 publicações por ano até 2016, para 73 publicações em 2018. Isso pode ser explicado por conta da recente abordagem de Internet of Things, que iniciou os estudos por volta de 2010, como visto no trabalho de Atzori, lera e Morabito (2010) e sua expansão para os assuntos agrícolas nos anos seguintes. Entende-se que o tema entrou nas pautas de pesquisa a partir de 2017. 
Figura 01 - Evolução das publicações ao longo do tempo

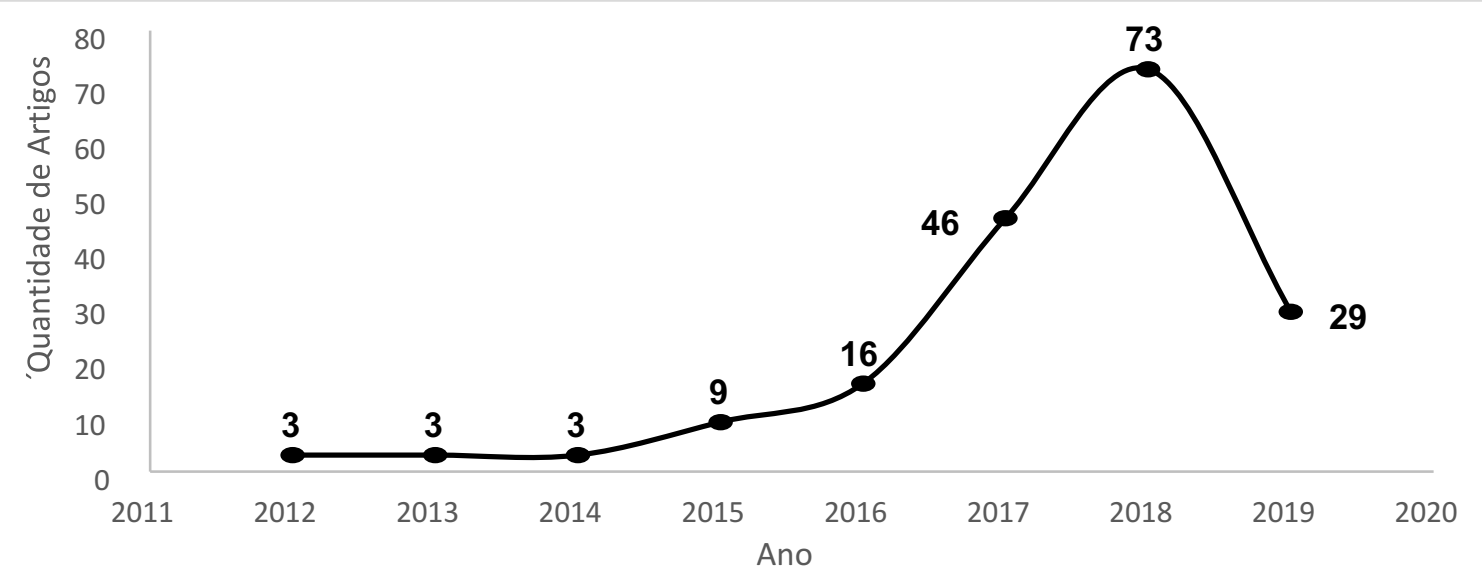

Fonte: Autor

Posteriormente, analisou-se os periódicos mais influentes no tema (a influência é medida em quantidade de publicações), bem como suas publicações ao longo dos anos. Na Tabela 01 encontra-se a quantidade de publicações dos periódicos mais influentes ao longo dos anos.

Tabela 01 - Quantidade de publicações por periódico

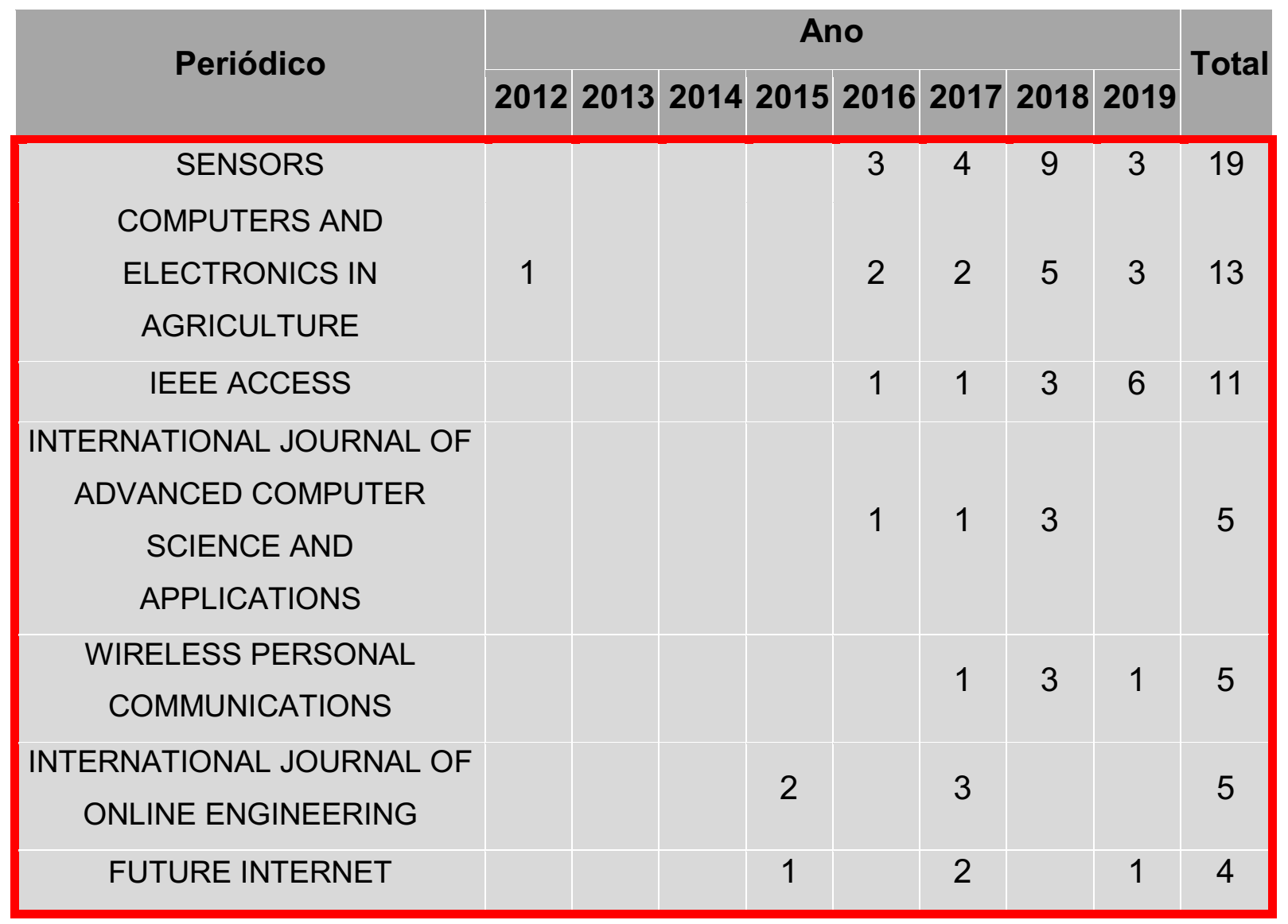




\begin{tabular}{|c|c|c|c|c|c|c|c|}
\hline $\begin{array}{c}\text { IEEE INTERNET OF THINGS } \\
\text { JOURNAL }\end{array}$ & & & & & 3 & & 3 \\
\hline $\begin{array}{c}\text { INTERNATIONAL JOURNAL OF } \\
\text { AGRICULTURAL AND } \\
\text { BIOLOGICAL ENGINEERING }\end{array}$ & & & & 1 & 2 & & 3 \\
\hline SUSTAINABILITY & & & & 1 & & 2 & 3 \\
\hline $\begin{array}{c}\text { FUTURE GENERATION } \\
\text { COMPUTER SYSTEMS-THE } \\
\text { INTERNATIONAL }\end{array}$ & & & & & 3 & & 3 \\
\hline $\begin{array}{l}\text { IEEE COMMUNICATIONS } \\
\text { MAGAZINE }\end{array}$ & & & & 1 & 1 & 1 & 3 \\
\hline $\begin{array}{l}\text { WIRELESS COMMUNICATIONS } \\
\text { \& MOBILE COMPUTING }\end{array}$ & 1 & & & 1 & 1 & & 3 \\
\hline MODERN PHYSICS LETTERS B & & & & 2 & & & 2 \\
\hline $\begin{array}{l}\text { INTERNATIONAL SUGAR } \\
\text { JOURNAL }\end{array}$ & & & & 1 & 1 & & 2 \\
\hline $\begin{array}{c}\text { INFORMATION SYSTEMS } \\
\text { FRONTIERS }\end{array}$ & & 2 & & & & & 2 \\
\hline HELIX & & & & & 1 & 1 & 2 \\
\hline $\begin{array}{c}\text { JOURNAL OF } \\
\text { ORGANIZATIONAL AND END } \\
\text { USER COMPUTING }\end{array}$ & & & & 1 & 1 & & 2 \\
\hline $\begin{array}{l}\text { INTERNATIONAL JOURNAL OF } \\
\text { COMPUTER SCIENCE AND } \\
\text { NETWORK SECURITY }\end{array}$ & & & & 1 & & 1 & 2 \\
\hline $\begin{array}{c}\text { PERSONAL AND UBIQUITOUS } \\
\text { COMPUTING }\end{array}$ & & 1 & 1 & & & & 2 \\
\hline IEEE SENSORS JOURNAL & & & & & 2 & & 2 \\
\hline ERCIM NEWS & & & & & 2 & & 2 \\
\hline
\end{tabular}

Do total de 103 periódicos que abordaram o assunto, sete destes ( $7 \%$ dos periódicos) apresentam 62 publicações (34\% dos artigos), representando uma concentração e desencadeando em um novo filtro na base de dados. 
Os sete periódicos com mais publicações são o Sensors $(J C R=2.475)$, Computers and Electronics in Agriculture (JCR $=2.761)$, IEEE Access $(J C R=3.557)$, International Journal of Advanced Computer Science and Applications $(J C R=1.324)$, Wireless Personal Communications $(J C R=1.200)$, International Journal of Online Engineering $(\mathrm{JCR}=0.500)$ e o Future Internet $(\mathrm{JCR}=1.12)$.

Para análise das citações, o Vosviewer é um dos softwares que viabiliza a verificação das relações entre os artigos e suas referências (LOPES, 2018). Desta maneira, algumas análises foram possíveis através dos gráficos provenientes do software, como pode ser verificado na Figura 02.

Figura 02 - Palavras mais utilizadas em Títulos e Resumos

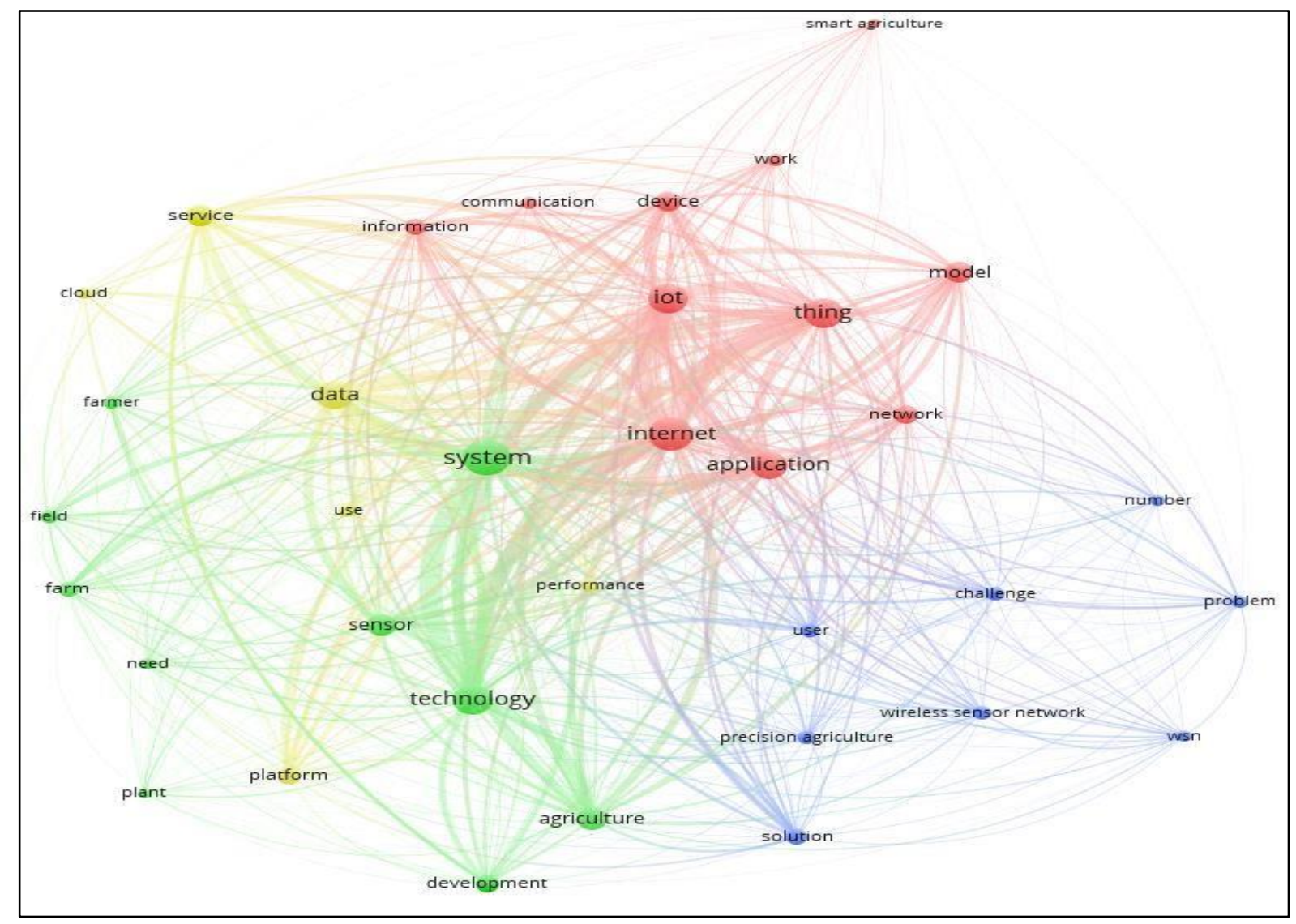

Fonte: Autor

Na Figura 02, o gráfico contém as palavras que apareceram pelo menos 20 vezes nos resumos, títulos e palavras chaves dos artigos publicados. Alguns clusters se formaram, sendo o de cor vermelha inclinado para o conceito de Internet of Things, 
o azul inclinado para as tecnologias que podem ser utilizadas no campo e o verde é mais relacionado a agricultura.

A palavra "Solution", traduzida como "Solução" tem seus principais vínculos com as palavras "Internet", "Things" e "IoT", demonstrando que o conceito de loT pode ser visto como uma solução dentro dos estudos no ramo da agricultura. Outra análise possível do mapa é a alta incidência das palavras "Sistema" e "Tecnologia", palavras genéricas altamente relacionadas a Internet of Things e que estão interligadas pelo mapa com as palavras do cluster verde (relacionado a agricultura), demonstrando que tanto sistemas quanto tecnologia podem ser assuntos relevantes na concepção de loT no campo.

Na Figura 03, registra-se a coautoria dos artigos (com pelo menos 2 artigos relacionados ao autor).

Figura 03 - Coautoria de artigos

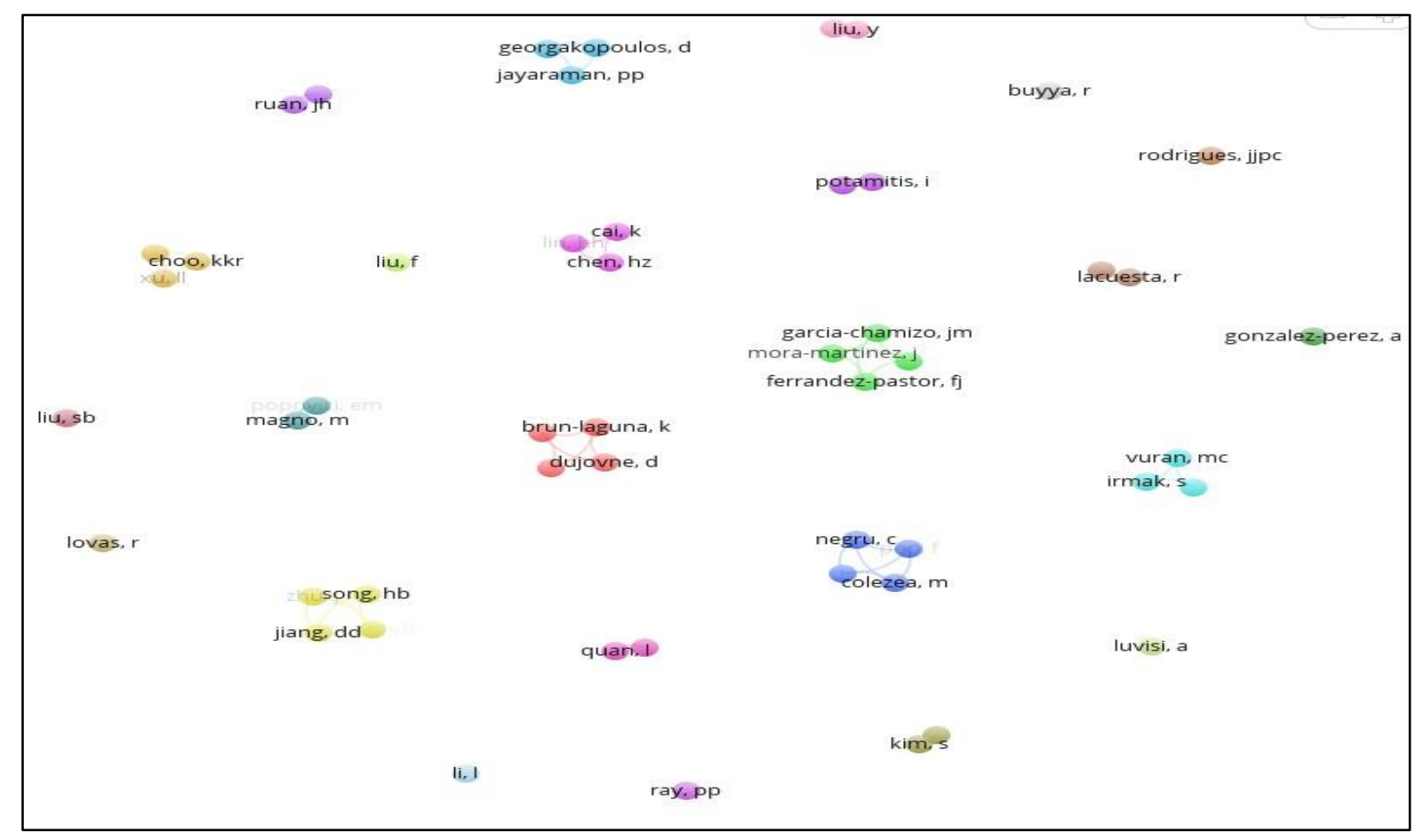

Fonte: Autor

Ao verificar as coautorias, compreende-se que os autores não têm grandes conexões nas redes, estabelecendo núcleos isolados de pesquisa e não concentrando uma gama de especialistas no assunto. 
Ao adentrar a leitura dos 62 artigos, verificou-se que 24 artigos não se enquadravam dentro do tema internet of things e agricultura, pois contém especificações somente de Internet of Things, com o uso das palavras "agriculture" e "farm" de maneira genérica no resumo.

Na figura 04, segue processo de seleção dos artigos.

Figura 04 - Processo de Seleção dos Artigos

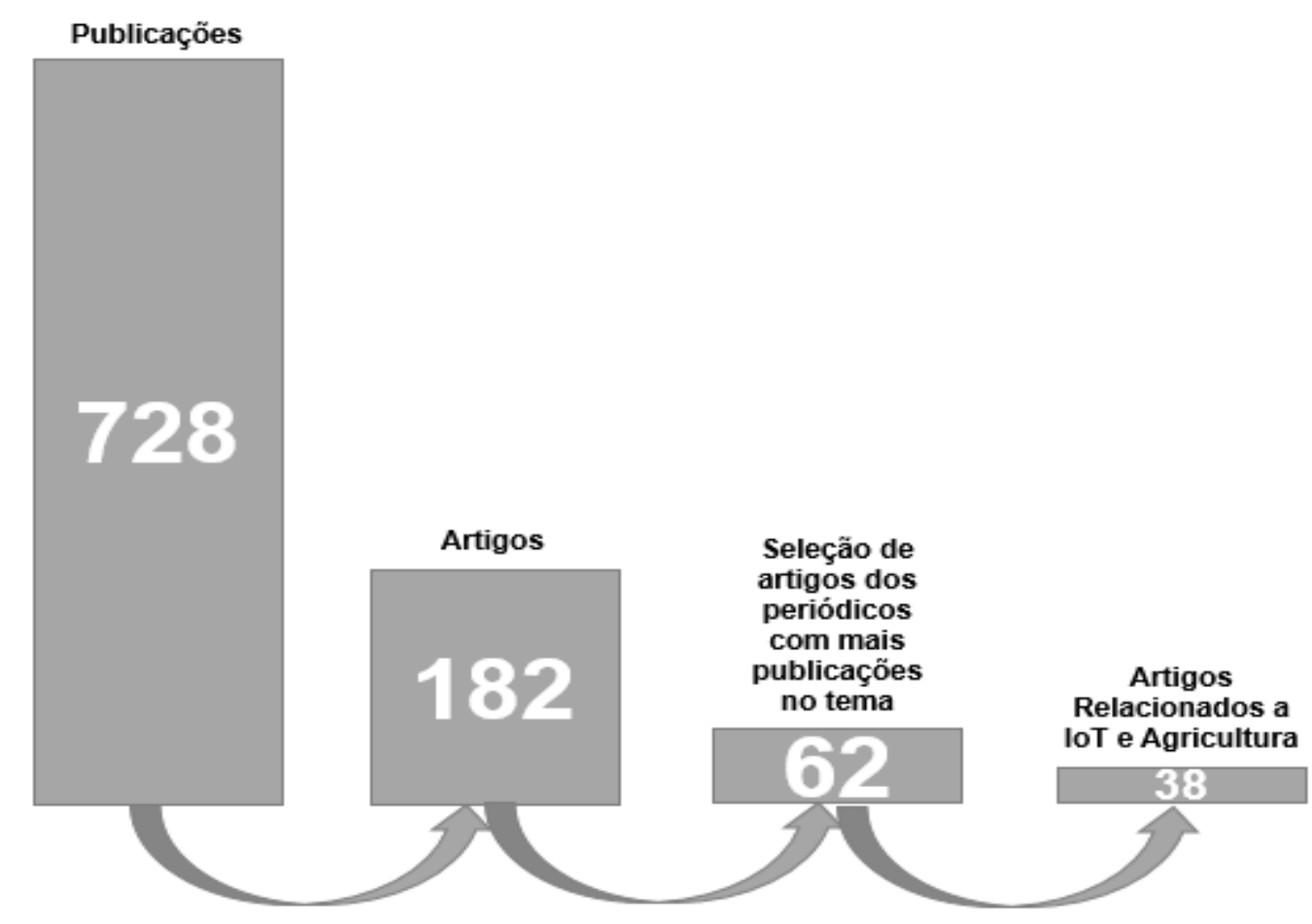

Fonte: Autor

Com a retirada dos 24 artigos, restaram 38 artigos que estão referenciados na tabela APÊNDICE A, dos quais $76,3 \%$ utilizaram experimento como método de pesquisa e $23,7 \%$ utilizaram o estudo de caso. Isso é explicado pois a maioria dos artigos têm foco técnico, para desenvolvimento de sistemas, algoritmos, aplicativos, sensores e dispositivos de internet of things no ambiente agrícola. Desta maneira, explicita-se a necessidade de mais estudos de caso no entendimento da adoção da internet of things na agricultura.

$\mathrm{Na}$ Tabela 02, ao classificar os artigos por temas, verifica-se que a maioria das publicações são voltadas para sistemas, como explicitado no mapa do vosviewer presente na Figura 02. 
Tabela 02 - Categorias de Temas

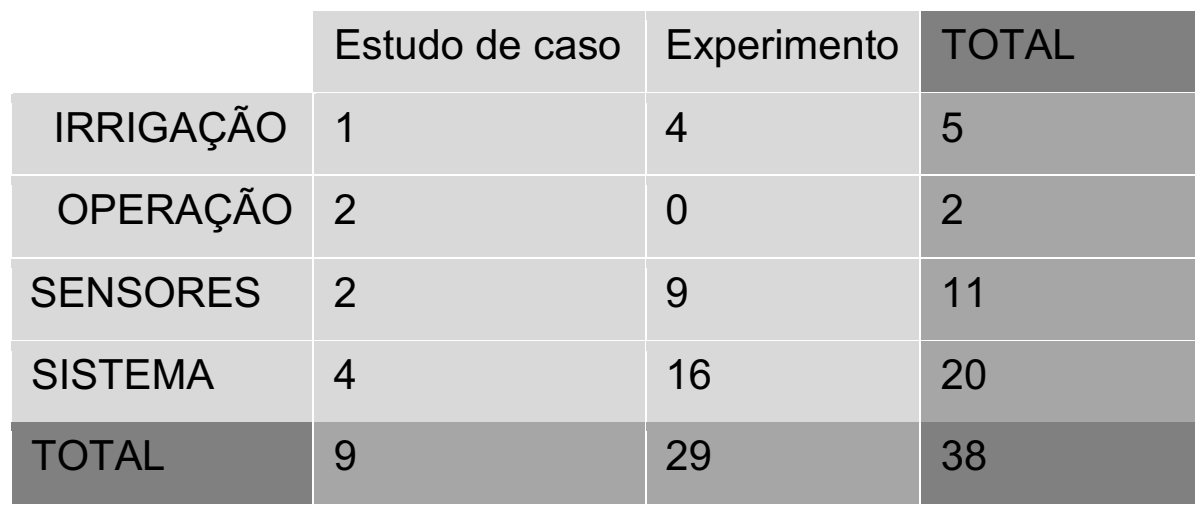

Fonte: Autor

Novamente demonstra-se o foco mais técnico dado a internet of things na agricultura, com apenas dois artigos voltados para o entendimento de gestão de operações.

$\mathrm{Na}$ Tabela 03, analisa-se as principais tecnologias estudadas nos artigos.

Tabela 03 - Tecnologias

\begin{tabular}{|c|c|c|c|c|c|}
\hline TECNOLOGIA & IRRIGAÇÃO & OPERAÇÃO & SENSORES & SISTEMA & TOTAL \\
\hline Cloud Computing & 0 & 0 & 0 & 3 & 3 \\
\hline $\begin{array}{c}\text { Drone } \\
\text { Inteligência }\end{array}$ & 0 & 0 & 1 & 0 & 1 \\
\hline $\begin{array}{c}\text { Artificial } \\
\text { Precision }\end{array}$ & 1 & 0 & 0 & 0 & 1 \\
\hline Agriculture & 0 & 1 & 2 & 3 & 6 \\
\hline System & 4 & 1 & 1 & 10 & 16 \\
\hline Video Data & 0 & 0 & 1 & 3 & 4 \\
\hline WSN & 0 & 0 & 6 & 1 & 7 \\
\hline TOTAL & 5 & 2 & 11 & 20 & 38 \\
\hline
\end{tabular}

Fonte: Autor

A tabela 03 confirma a tendência de estudos sistêmicos de internet of things, junto a utilização de sensores Wireless Sensors Network (WSN) e agricultura de precisão. Dobrescu, Merezeanu e Mocanu (2019) afirmam que Internet of Things está 
sendo usada cada vez mais associada a agricultura de precisão junto à tecnologias de sensoriamento para a coleta de dados e monitoramento da produção.

Para buscas relacionadas a adoção de tecnologia junto a Internet of Things e Agricultura, as bases retornam poucas publicações, o que inviabiliza a execução de bibliometria para esta composição.

Nas seções a seguir algumas definições dos conceitos de internet of things, produção de hortaliças e modelos de adoção de tecnologia.

\subsection{INTERNET OF THINGS}

O conceito de Internet of Things (IOT) é dividido nas duas palavras "Internet" e "Things", sendo que o termo "coisa" se refere aos dispositivos com identidade única, com sensoriamento remoto e que atuam em tempo real com alguns tipos de dados e "Internet" é definida como a conexão de rede de comunicação global para compartilhamento de informações (ATZORI; IERA; MORABITO, 2010).

Ainda Atzori, lera e Morabito (2010), definem que dispositivos utilizados em Internet of Things estão habilitados para realizar troca de dados ao vivo com outros dispositivos e aplicativos, processar os dados e enviar os dados para vários servidores. A conexão Machine-to-Machine (M2M) é um componente crucial para digitalização e Internet of Things (RAY, 2017).

O termo Internet of Things também pode ser definido como nós de uma variedade de coisas ou objetos, tais como Radio Frequency Identification (RFID), sensores, celulares, entre outros, que são capazes de interagir entre si e cooperar com os demais dispositivos para alcançar determinado objetivo (GIUSTO et al., 2010; GUBBI et al. 2013).

Farooq et al. (2015) definem quatro níveis de aplicação de Internet of Things:

1) Camada de diferentes sensores e coletores de dados;

2) Camada de rede que controla a transmissão de dados;

3) Camada de middleware, onde ocorre o processamento de informações;

4) Camada de aplicativos e serviços. 
As principais dificuldades enfrentadas para aplicação de Internet of Things é a falta de padrão para interconexão, preocupações com segurança e privacidade (CARCARY et al., 2018). Ahmed e De (2018) também afirmam que a privacidade é necessária para que dispositivos individuais se comuniquem de forma autônoma em diferentes plataformas, nuvens e na internet como um todo.

Algumas tecnologias levantadas que sustentam o termo Internet of Things encontram-se no Quadro 01.

Quadro 01 - Tecnologias relacionada a Internet of Things

\begin{tabular}{|c|c|c|}
\hline RFID & $\begin{array}{l}\text { É um sistema de identificação única que } \\
\text { utiliza ondas de rádio para transmitir } \\
\text { informações disponíveis sobre objetos ou } \\
\text { pessoas }\end{array}$ & $\begin{array}{l}\text { (SHAHZADI, } \\
\text { 2016; XU e LU, } \\
\text { 2018; GUBBI et } \\
\text { al., 2013; WEY; } \\
\text { LV, 2018) }\end{array}$ \\
\hline $\begin{array}{c}\text { Sensores e } \\
\text { WSN }\end{array}$ & $\begin{array}{l}\text { A tecnologia de sensores é referente a um } \\
\text { equipamento ou dispositivo que converte } \\
\text { variáveis do ambiente em sinais elétricos } \\
\text { para que possam ser medidos e } \\
\text { processados. Já o WSN são sensores com } \\
\text { capacidade de auto-rede, sem fio, com baixo } \\
\text { consumo de energia e requerem uma } \\
\text { mínima intervenção humana. O WSN } \\
\text { também pode ser definido como vários } \\
\text { sensores integrados para monitorar vários } \\
\text { tipos de dados. }\end{array}$ & $\begin{array}{l}\text { (SHAHZADI, } \\
\text { 2016; XU; LU, } \\
\text { 2018; WEY; LV, } \\
\text { 2018; NAYYAR; } \\
\text { PURI, 2017) }\end{array}$ \\
\hline $\begin{array}{l}\text { Video } \\
\text { Surveillance } \\
\text { Technology }\end{array}$ & $\begin{array}{l}\text { Sistema de monitoramento de vídeo remoto, } \\
\text { onde realiza a rastreabilidade visual e } \\
\text { armazena no servidor da rede. }\end{array}$ & (WEY; LV, 2018) \\
\hline $\begin{array}{l}\text { Global } \\
\text { Position } \\
\text { System } \\
\text { (GPS) e }\end{array}$ & $\begin{array}{l}\text { Sistema de posicionamento de espaço, } \\
\text { através da utilização de rádio frequencia } \\
\text { conectadas a satélites, com informações em } \\
\text { tempo real, de alta precisão e contínuas. }\end{array}$ & $\begin{array}{l}(X U ; \quad \text { LU, 2018; } \\
\text { WEY, LV, 2018) }\end{array}$ \\
\hline
\end{tabular}




\begin{tabular}{|c|c|c|}
\hline $\begin{array}{c}\text { Information } \\
\text { System }\end{array}$ & & \\
\hline $\begin{array}{c}\text { Cloud } \\
\text { Computing }\end{array}$ & $\begin{array}{l}\text { Atua com o armazenamento dos dados } \\
\text { dectados, permite realizar análises nos } \\
\text { dados coletados e o acesso centralizado das } \\
\text { informações. Pode ser entendido também } \\
\text { como processamento compartilhado de } \\
\text { recursos, dados e computadores para } \\
\text { dispositivos sob demanda. }\end{array}$ & $\begin{array}{l}\text { (BOTTA et al. } \\
2014 ; \quad \text { NAYYAR; } \\
\text { PURI, 2017) }\end{array}$ \\
\hline $\begin{array}{c}\text { Data } \\
\text { Analytics ou } \\
\text { Big Data }\end{array}$ & $\begin{array}{l}\text { Gererenciamento e análise de uma grande } \\
\text { quantidade de dados que auxiliam na } \\
\text { tomada de decisão. Pode ser utilizado para } \\
\text { desenvolvimento de modelos de previsão. }\end{array}$ & $\begin{array}{l}\text { (GUBBI et al., } \\
\text { 2013, NAYYAR; } \\
\text { PURI, 2017) }\end{array}$ \\
\hline
\end{tabular}

Fonte: Autor

Em Nayyar e Puri (2017) encontram-se mais algumas tecnologias e métodos relacionados, como:

- Big Data Analytics: é definido como o processo de analisar grandes volumes de dados em suas diversas formas para criar padrões, correlações, tendências e informações.

- Protocolos de Comunicação: formam os sistemas de Internet of Things para garantir conectividade e interconexão de dispositivos com a rede, permitindo troca de dados, codificação e endereçamento.

- Sistemas Embarcados: são estruturas formadas por software e hardware para realizar tarefas específicas, incluindo microprocessador, memória, componentes de rede e unidades de armazenamento.

No item 2.2, discute-se a aplicação de Internet of Things na Agricultura.

\subsection{INTERNET OF THINGS E AGRICULTURA}

A agricultura fornece alimentos, grãos e outras matérias primas que são a base para a vida humana e a tecnologia é o caminho para aumento na eficiência da produção no campo (BHAGWAT; RAMAN; SANGHI, 2004). Hussain (2016) 
contextualizou a importância da tecnologia, em que o uso de Internet of Things seria a solução para o aumento da eficiência na agricultura, criando plantios inteligentes.

Ojha, Misra e Raghuwanshi (2015) entendem que recursos como a integração de sensores, transmissão digital e WSN permitem utilizar diferentes dispositivos que viabilizam Internet of Things no campo. Algumas práticas que seriam viabilizadas com o uso do loT é a irrigação inteligente, otimização do uso de fertilizantes, controle de pragas e monitoramento da água e do solo.

Outras atividades agrícolas que são auxiliadas por meio de Internet of Things são o próprio plantio das sementes, pulverização, afastamento de pássaros e animais (GONDCHAWAR; KAWITKAR, 2016). Mekala e Viswanathan (2017) reforçam também que o uso eficiente de fertilizantes e pesticidas podem ser feitos com loT.

Zhao et. al (2011) e Arooj, Asif e Shah (2017) definem que os sistemas de monitoramento do cultivo possibilitam uma tomada de decisão no tempo correto, com armazenamento histórico e contínuo. Os parâmetros que são analisados nestes sistemas são: temperatura, umidade do ambiente e do solo, , velocidade e direção do vento, imagens das culturas e precipitação.

Ainda sobre os parâmetros, Ferrández-Pastor et al. (2016) explicita que agrônomos estão utilizando estufas experimentais para compreender os dados obtidos no sensoriamento das culturas, no qual absorvem informações sobre o PH da água e do solo, temperatura da água, do solo e do ambiente e a umidade relativa e como estas informações impactam no uso de luzes, bombas e máquinas agrícolas.

No domínio da agricultura, Aliev et al. (2018) afirma que é necessária a comunicação de longa distância e maior eficiência de energia, com uso de tecnologias como o WSN, que viabiliza o monitoramento do cultivo e aplicações agrícolas inteligentes no campo.

No que tange à questões de segurança, as tecnologias de rastreamento e monitoramento são as principais soluções de Internet of Things, possibilitando garantir a segurança e qualidade de alimentos, construindo uma rede de informações para tomada de decisões e gerenciamento efetivo dos produtos não só no plantio, mas na cadeia de suprimentos agrícola como um todo (PANDURU et al., 2016)

Nayyar e Puri (2017) definem o termo "Agricultural loT" para exemplificar os conceitos que tangenciam Internet of Things com produção agrícola. A seguir alguns conceitos de aplicação: 
- Crop Water Management: Utilização de WSN e sensores para o gerenciamento inteligente da irrigação, reduzindo desperdício de água;

- Agricultura de precisão: Alta precisão em relação a informação meteorológica, entrega de dados em tempo real, em termos de previsão do tempo, qualidade do solo e custo do trabalho;

- Controle de Pestes e Gerenciamento Integrado: Dados ao vivo de temperatura, umidade, tamanho e nível de pragas na produção agrícola;

- Produção e segurança dos alimentos: monitoramento de temperatura no armazém, gestão de transporte e integração baseada em sistemas na nuvem.

Complementando a questão do Crop Water Management, para Difallah et al. (2018) uma das maiores contribuições de Internet of Things na agricultura é referente ao uso da água na irrigação. A integração de redes, sensores e tratamento de dados pode proporcionar soluções de uso da água para locais com falta de água, economizando o uso do recurso e garantindo alimentos. Difallah et al. (2018) ainda afirmam que existem outras vantagens do uso da tecnologia na agricultura, como o uso de informações em tempo real, a minimização da mão de obra, maior produtividade no plantio, uso eficiente da água.

Complementando a questão da agricultura de precisão, na fertilização do solo, a loT está cada vez mais associada a aplicação de nutrientes a uma taxa variável, de acordo com o sensoriamento do solo e a necessidade da cultura em questão (DOBRESCU; MEREZEANU; MOCANU, 2019).

Mekala e Viswanathan (2017) resumem que Internet of Things na produção agrícola pode ser entendida em quatro níveis de aplicação:

1) Camada da interface do usuário, como o celular do fazendeiro e dispositivos pessoais para monitorar a área de agricultura;

2) Gerenciamento de informações que contém a formação e classificação de dados, monitoramentos e tomada de decisão;

3) Gerenciamento de rede, que representa tecnologias como Gateway, RFID, GSM, WIFI, 3G e Bluetooth de baixa energia;

4) Coleta de informações, onde contém os sensores e as câmeras. 
Massruhá e Leite (2017) reforçam que métodos computacionais de alto desempenho, rede de sensores, comunicação máquina-para-máquina (M2M), conectividade entre dispositivos, computação em nuvem, processamento de grande de volume de dados e suporte a tomada de decisão são definidos como pilares da digitalização da agricultura.

\subsection{HORTALIÇAS}

No cenário brasileiro, diante dos desafios apresentados na agricultura, o setor demandará novas tecnologias voltadas para gestão de dados, informações e conhecimento, integrando mundo físico e digital. O setor deverá ampliar sua produção, sem aumentar sua área plantada, demandando maior eficiência (MASSRUHÁ, 2015).

A produção agrícola brasileira tem características variadas com diferenças regionais, de biomas e de escala de produção (SOUZA FILHO, 2011). Além de sua variedade, a agricultura brasileira vem modificando sua estrutura produtiva nas últimas décadas, utilizando novas técnicas e princípios, e assim reordenando o espaço produtivo rural (MATTEI, 2015).

No Brasil, o setor agropecuário foi responsável, em 2017, por 22,5\% do PIB e $37,5 \%$ da força de trabalho. As hortaliças, dentro deste contexto, geram cerca de 2 milhões de empregos diretos, ocupam um território aproximado de 350 mil hectares e produzem cerca de 12 milhões de toneladas de alimentos (EMPRAPA, 2018).

Para a CONAB (2019), a Companhia Nacional de Abastecimento, as cinco principais hortaliças são a alface, batata, cebola, cenoura e tomate. São classificados como os principais produtos devido à alta comercialização nas centrais de abastecimento do Brasil e pelo seu destaque no cálculo do índice de inflação oficial, o IPCA (Índice Nacional de Preços ao Consumidor Amplo).

No Quadro 02 apresentam-se os estados produtores das hortaliças comercializadas nos principais entrepostos do país segundo a CONAB (2019).

Quadro 02 - Estados Produtores de Hortaliças

\section{PRODUTO $\quad$ ESTADOS DA ORIGEM DA PRODUÇÃO DE HORTALIÇAS}




\begin{tabular}{|c|c|} 
ALFACE & $\begin{array}{c}\text { PARANÁ, SÃO PAULO, RIO DE JANEIRO, ESPIRITO SANTO, } \\
\text { MINAS GERAIS, GOIAS, DISTRITO FEDERAL, PERNAMBUCO } \\
\text { E CEARÁ }\end{array}$ \\
\hline BATATA & $\begin{array}{c}\text { PARANÁ, SÃO PAULO, MINAS GERAIS, GOIAS, DISTRITO } \\
\text { FEDERAL E BAHIA }\end{array}$ \\
\hline CEBOLA & $\begin{array}{c}\text { RIO GRANDE DO SUL, SANTA CATARINA, PARANÁ, SÃO } \\
\text { PAULO, MINAS GERIAS, ESPIRITO SANTO, GOIAS, BAHIA, } \\
\text { PERNAMBUCO, RIO GRANDE DO NORTE }\end{array}$ \\
\hline CENOURA & $\begin{array}{c}\text { SANTA CATARINA, PARANÁ, SÃO PAULO, MINAS GERAIS, } \\
\text { ESPIRITO SANTO, GOIAS, DISTRITO FEDERAL E BAHIA }\end{array}$ \\
\hline TOMATE & $\begin{array}{c}\text { PARANÁ, SÃO PAULO, RIO DE JANEIRO, ESPIRITO SANTO, } \\
\text { MINAS GERAIS, GOIAS, PERNAMBUCO E CEARÁ }\end{array}$ \\
\hline
\end{tabular}

Fonte: Autor "adaptado de" CONAB, 2019

Verifica-se que os estados do Paraná, São Paulo, Minas Gerais e Goiás são os que abrangem a produção dos cinco produtos e abastecem os maiores entrepostos do país.

Nas tabelas 04 e 05, obtidas através da CONAB (2019), demonstram-se o volume de vendas em toneladas e em valor monetário das hortaliças que foram comercializadas nos maiores entrepostos do Brasil.

Tabela 04 - Quantidade Comercializada de Hortaliças

\begin{tabular}{|l|r|r|r|r|r|}
\hline \multirow{2}{*}{ ANO } & \multicolumn{1}{|c|}{$\begin{array}{c}\text { ALFACE } \\
\text { Quantidade } \\
(\mathbf{K g})\end{array}$} & $\begin{array}{c}\text { BATATA } \\
\text { Quantidade } \\
(\mathbf{K g})\end{array}$ & $\begin{array}{c}\text { CEBOLA } \\
\text { Quantidade } \\
\mathbf{( K g )}\end{array}$ & $\begin{array}{c}\text { CENOURA } \\
\text { Quantidade } \\
(\mathbf{K g})\end{array}$ & $\begin{array}{c}\text { TOMATE } \\
\text { Quantidade } \\
(\mathbf{K g})\end{array}$ \\
\hline 2010 & 6.657 .512 & 79.046 .751 & 31.654 .867 & 30.766 .083 & 84.564 .080 \\
\hline 2011 & 6.727 .792 & 98.228 .741 & 34.759 .444 & 32.322 .497 & 83.565 .653 \\
\hline 2012 & 8.292 .346 & 96.065 .105 & 33.275 .762 & 33.990 .318 & 82.225 .158 \\
\hline 2013 & 7.599 .597 & 86.868 .728 & 34.628 .084 & 32.548 .767 & 75.531 .660 \\
\hline 2014 & 9.027 .733 & 108.284 .759 & 36.366 .332 & 32.542 .735 & 91.827 .626 \\
\hline 2015 & 8.979 .779 & 97.469 .977 & 38.692 .298 & 33.340 .174 & 86.539 .611 \\
\hline 2016 & 10.057 .539 & 101.529 .091 & 39.662 .100 & 32.354 .909 & 76.875 .653 \\
\hline 2017 & 9.027 .608 & 117.960 .604 & 45.925 .114 & 31.560 .543 & 88.740 .810 \\
\hline 2018 & 8.301 .371 & 114.650 .358 & 43.770 .639 & 29.667 .661 & 80.374 .773 \\
\hline 2019 & 8.325 .288 & 103.187 .870 & 44.221 .907 & 28.953 .107 & 87.772 .393 \\
\hline
\end{tabular}

Fonte: Autor "adaptado de" CONAB, 2019

Tabela 05 - Valor monetário da comercialização de hortaliças 


\begin{tabular}{|l|c|c|r|r|r|}
\hline \multirow{2}{*}{ ANO } & ALFACE & \multicolumn{1}{c|}{ BATATA } & \multicolumn{1}{c|}{ CEBOLA } & \multicolumn{1}{c|}{ CENOURA } & \multicolumn{1}{c|}{ TOMATE } \\
\cline { 2 - 6 } & Valor (R\$) & Valor (R\$) & \multicolumn{1}{c|}{ Valor (R\$) } & Valor (R\$) & Valor (R\$) \\
\hline 2010 & 10.470 .294 & 98.781 .947 & 39.147 .161 & 38.025 .644 & 86.793 .389 \\
\hline 2011 & 13.691 .332 & 72.144 .813 & 26.057 .779 & 34.464 .849 & 116.347 .799 \\
\hline 2012 & 11.187 .396 & 77.679 .096 & 33.574 .373 & 33.204 .945 & 137.286 .185 \\
\hline 2013 & 24.195 .843 & 132.620 .578 & 57.722 .170 & 38.715 .370 & 210.836 .209 \\
\hline 2014 & 22.494 .994 & 137.738 .291 & 46.474 .809 & 45.134 .313 & 158.205 .917 \\
\hline 2015 & 25.989 .813 & 216.724 .123 & 60.234 .341 & 49.372 .294 & 193.515 .558 \\
\hline 2016 & 33.788 .767 & 247.919 .667 & 120.474 .853 & 82.367 .675 & 299.844 .128 \\
\hline 2017 & 19.551 .836 & 141.560 .912 & 64.315 .839 & 39.246 .248 & 128.943 .670 \\
\hline 2018 & 20.084 .851 & 177.920 .128 & 70.071 .444 & 55.680 .337 & 227.483 .289 \\
\hline 2019 & 23.842 .097 & 186.520 .076 & 107.677 .931 & 61.203 .362 & 202.607 .604 \\
\hline
\end{tabular}

Fonte: Autor "adaptado de" CONAB, 2019

Pelos números é possível analisar que as produções em toneladas de alface, batata e cebola cresceram mais de $25 \%$ em 10 anos, enquanto as de cenoura e tomate se mantiveram no mesmo patamar. Sob o ponto de vista do valor comercializado, todos os itens apresentaram aumento, todos acima do aumento em quantidade, demonstrando um ganho através da elevação dos preços dos produtos.

No item 2.3.1 analisa-se as práticas necessárias para o plantio de hortaliças e no 2.3.2 as etapas do pós-colheita.

\subsubsection{Plantio de hortaliças}

O plantio das hortaliças pode ocorrer de diferentes maneiras, porém a mais comum é produção em canteiros localizados no chão, que é o caso da alface, da batata, cebola e cenoura. Já o tomate é plantado em leirões ou camalhões que são canteiros estreitos com uma ou duas filas de plantas (EMBRAPA, 2006).

Os canteiros devem ter pelo menos 11 centímetros de altura, 1,20 metro de largura na base e 1 metro de largura na crista para proteger da umidade excessiva do solo que pode causar doenças nas plantas. Já os leirões ou camalhões devem ter a mesma altura dos canteiros, porém com alterações nas medidas da largura da base (no máximo 60 centímetros) e da crista (no máximo 30 centímetros com o intuito de aproximar as plantas (EMBRAPA, 2006).

$\mathrm{Na}$ tabela 06, verifica-se as especificações técnicas do plantio de cada hortaliça. 
Tabela 06 - Especificações das hortaliças

\begin{tabular}{|c|c|c|c|c|c|}
\hline ESPECIFICAÇÕES & ALFACE & BATATA & CEBOLA & CENOURA & TOMATE \\
\hline Dias para germinação & 4 dias & - & 6 dias & 7 a 21 dias & 5 dias \\
\hline Temperatura germinação & $24^{\circ} \mathrm{C}$ & - & $24^{\circ} \mathrm{C}$ & $27^{\circ} \mathrm{C}$ & $29^{\circ} \mathrm{C}$ \\
\hline PH do solo & 5,8 a 6,7 & 7 & 5,5 a 6,5 & 6 a 6,8 & 5,5 a 6,5 \\
\hline Tempo de Ciclo Verão & 45 dias & 90 a 120 dias & 130 dias & 80 dias & 120 dias \\
\hline Tempo de Ciclo Inverno & 65 dias & 90 a 120 dias & 130 dias & 80 dias & 120 dias \\
\hline $\begin{array}{l}\text { Padrão Comercial } \\
\text { (Tamanho/Peso) }\end{array}$ & $20-30 \mathrm{~cm}$ & Diâmetro $4 \mathrm{~cm}$ & $8-9 \mathrm{~cm}$ & $20 \mathrm{~cm}$ & $120-150 \mathrm{~g}$ \\
\hline Época de cultivo & O ano todo & Abril a Outubro & Abril a Junho & O ano todo & $\begin{array}{l}\text { O ano } \\
\text { todo }\end{array}$ \\
\hline $\begin{array}{c}\text { Profundidade máxima } \\
\text { semeadura }\end{array}$ & $1 \mathrm{~cm}$ & $3 \mathrm{~cm}$ & $0,5 \mathrm{~cm}$ & $0,5 \mathrm{~cm}$ & $1 \mathrm{~cm}$ \\
\hline
\end{tabular}

Fonte: Autor “adaptado de" Isla, 2019 e Embrapa, 2019

Mesmo seguindo as especificações, outros fatores são importantes no contexto do plantio. Por exemplo, a nutrição e adubação são essenciais para o crescimento da hortaliça, logo a falta destas práticas ocasiona na falta de nitrogênio (redução do crescimento e amarelamento), falta de potássio (redução do crescimento e maturação anormal) e falta de boro (reduz preenchimento da planta). Já a irrigação é importante, porém de maneira dosada, uma vez que o excesso de água torna a hortaliça suscetível a podridão e a falta de água o ressecamento e rachaduras (EMBRAPA, 2011).

No mesmo estudo, a EMBRAPA (2011) recomenda o controle fitossanitária contra doenças, pragas e ervas daninhas que ataquem as hortaliças, para garantir a prosperidade do produto tanto na colheita quanto no pós-colheita. Qualquer foco de decomposição e deterioração deve ser atacado. Por fim, o ponto final do plantio que é a colheita, deve ser referenciado conforme a preferência do consumidor, seja com um produto mais maduro ou mais "verde".

No Quadro 03 segue resumo das especificações feitas pela EMBRAPA (2011) para o momento da colheita das hortaliças deste estudo. 


\begin{tabular}{|c|c|}
\hline Alface & $\begin{array}{c}\text { A planta deve apresentar desenvolvimento máximo, sem indício de } \\
\text { apendoamento, ou seja, o alongamento do caule que precede o } \\
\text { florescimento }\end{array}$ \\
\hline Batata & $\begin{array}{c}\text { Para consumo, a batata deve ser colhida com as ramas já } \\
\text { senescentes, prostradas e película bem aderida à polpa } \\
\text { A colheita da cebola deve ser feita quando cerca de } 70 \% \text { das } \\
\text { plantas tiverem sofrido tombamento ("estalo") e amarelecimento } \\
\text { das folhas. Para que as ramas fiquem enxutas, a irrigação deve } \\
\text { ser suspensa de 2 a 3 semanas antes da colheita. }\end{array}$ \\
\hline Cenoura & $\begin{array}{c}\text { As raízes devem ser colhidas com } 12 \mathrm{~cm} \text { a } 20 \mathrm{~cm} \text { de comprimento } \\
\text { por 2 cm a } 4 \mathrm{~cm} \text { de diâmetro. As raízes de maior valor comercial } \\
\text { são firmes, têm cor laranja intensa, e não possuem ombro verde. }\end{array}$ \\
\hline Tomate & $\begin{array}{c}\text { A colheita deve ser feita quando aparecerem os primeiros sinais de } \\
\text { cor amarelo tanino ou avermelhado no ápice do fruto. }\end{array}$ \\
\hline
\end{tabular}

Fonte: Autor "adaptado de" EMBRAPA, 2011

Ainda conforme a EMBRAPA (2011), a colheita deve ser realizada nos momentos mais frescos do dia (início da manhã ou final da tarde) para que a temperatura esteja mais baixa e a umidade relativa mais elevada. Deve-se ter cuidado com o manuseio, evitando recipientes que causem danos a plantação, com a superlotação de produtos nas caixas, apertar os produtos com o maquinário ou com as mãos e contaminação. Por fim, o método de colheita mecânico pode ser aplicado de melhor forma a raízes e tubérculos, em que se pode colher toda a lavoura de uma só vez. Já os demais produtos a tendência é a utilização da colheita manual.

\subsubsection{Pós-colheita}

Segundo o CEAGESP (2009) um dos principais pilares da pós-colheita é a aplicação do conceito de "Manuseio Mínimo", o qual reduz-se as possibilidades de deterioração no processo produtivo e de transporte das hortaliças. O produtor rural deve evitar o manuseio excessivo para não retirar as propriedades naturais do produto. Outro estudo feito pelo EMBRAPA (2011), explicita que as condições de cultivo são as únicas relacionadas a qualidade do produto, cabendo a pós colheita apenas manter a qualidade adquirida.

Outro fator importante ao cenário de pós colheita das hortaliças brasileiras é a recente exigência de rastreabilidade aos participantes da cadeia de abastecimento. $O$ objetivo é conhecer a procedência dos produtos através de rotulagens padronizadas, 
conforme a instrução Normativa Conjunta 02 da secretaria da Defesa Agropecuária do Ministério da Agricultura. Segundo CEAGESP (2019) o intuito da Instrução Normativa é identificar problemas com contaminação.

$\mathrm{Na}$ figura 05 , exemplifica-se o fluxo de produtos até o consumidor final, conforme CEAGESP (2009).

Figura 05 - Cadeia de Abastecimento

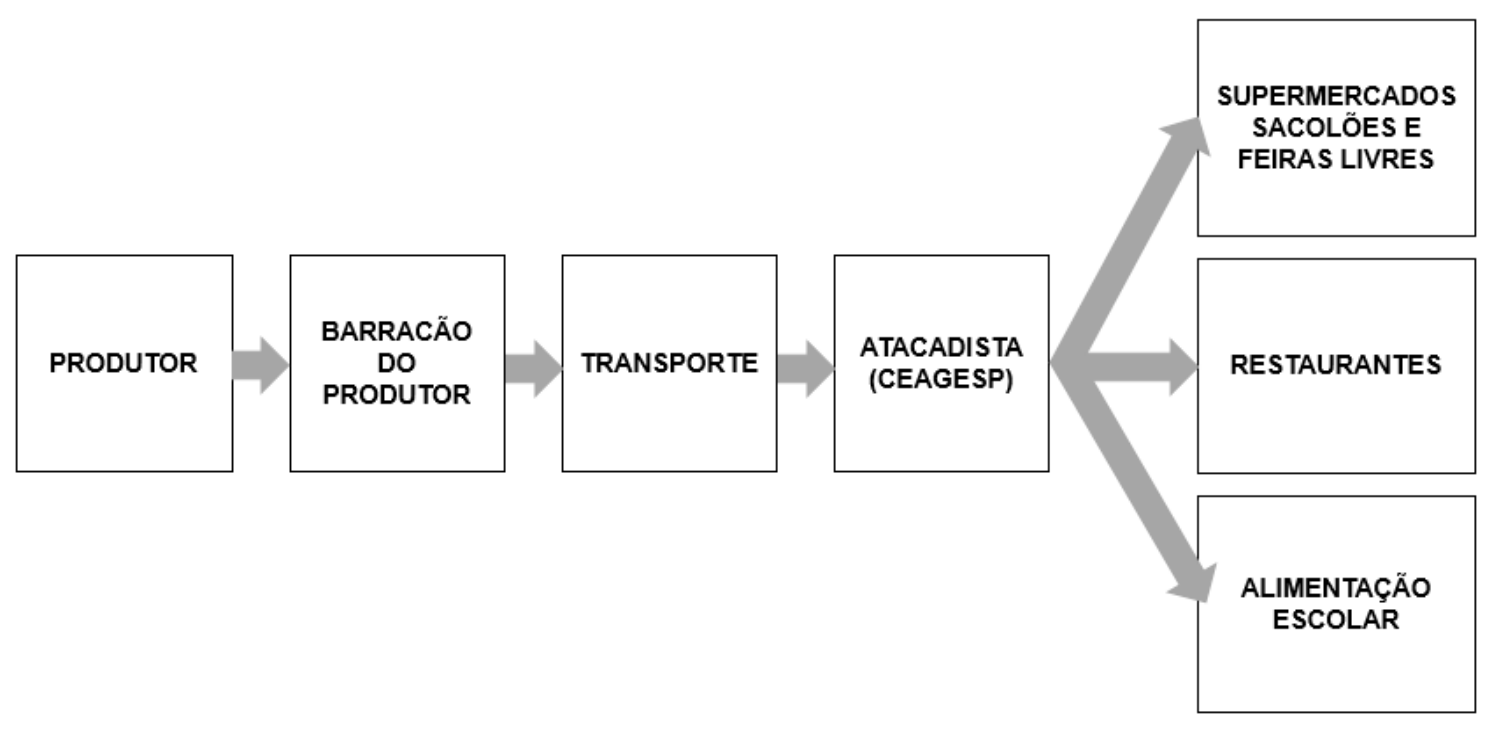

Fonte: Autor "adaptado de" CEAGESP, 2009

Novamente em EMBRAPA (2011), verifica-se que na etapa de pós colheita, para o armazenamento é necessário manter os produtos protegidos de insolação direta, armazenar em ambientes limpos a fim de reduzir a probabilidade de contaminação, evitar o contato de produtos estragados com os sadios, separar produtos maduros e imaturos, folhosas em ambientes úmidos e batatas em ambientes escuros.

Referente ao transporte, é recomendado viajar nas horas mais frescas do dia, fixar as caixas para evitar quedas, manter ventilação adequada e distribuir o peso da carga. Em países em desenvolvimento como o Brasil, falta de padrões para comercialização, embalagens inadequadas e estradas precárias contribuem para problemas no transporte (EMBRAPA, 2011).

A questão do pós colheita é relevante pois as estimativas de perdas no Brasil são em torno de 30\% (EMBRAPA, 2011). Em relatório apresentado pela FAO (2011), 
verifica-se que a questão da perda de alimentos é de grande importância nos esforços para combater a fome, aumentar a renda e melhorar segurança alimentar. Algumas das causas apontadas pelo estudo são influenciadas pela produção agrícola, a escolhas de padrões, infraestrutura, cadeias de comercialização e canais de distribuição, e por fim as práticas de compra e de uso dos alimentos pelo consumidor.

Para entender quais são as barreiras e habilitadores da adoção de internet of things no contexto do plantío, a seção 2.4 se aprofundará nos modelos de adoção de tecnologia.

\subsection{MODELOS DE ADOÇÃO DE TECNOLOGIA}

Modelos de adoção de tecnologia são necessários uma vez que para gerar resultados as tecnologias devem ser operacionalizadas e entendidas. Sua importância em relação a adoção se dá no estudo da resistência do usuário ou tomador de decisão, conforme visto em Davis, Bagozzi e Warshaw (1989).

Alguns destes modelos adoção de tecnologia tem como foco o indivíduo, como pode ser visto no Technology Acceptance Model (TAM) proposto por Davis, Bagozzi e Warshaw (1989), no Extended Technology Acceptance Model (TAM2) proposto por Venkatesh e Davis (2000), Unified Theory of Acceptance and Use of Technology (UTAUT) proposto por Venkatesh et al. (2003) e o mais recente Unified Theory of Acceptance and Use of Technology 2 (UTAUT 2) proposto por Venkatesh, Thong e Xu (2012). Para modelos que abordam análises em níveis gerenciais, há o Diffusion of Inovation (DOI) proposto por Rogers (1995) e o Technology-OrganizationEnvironment proposto por Tornatzky e Fleischer (1990).

Para a aplicação dos modelos individuais neste estudo, necessita-se entender o perfil do produtor rural brasileiro. Segundo estudo do SEBRAE (2012), 81,4\% dos estabelecimentos rurais apresentam um dirigente que possui ensino fundamental incompleto ou é analfabeto. Referente a idade destes produtores, a maioria se encontra em faixas etárias mais avançadas, representando um total de $61 \% \mathrm{com}$ mais de 45 anos. Já o perfil é amplamente dominado pelo sexo masculino, em que $87 \%$ dos dirigentes são homens. Por fim, no estudo do EMBRAPA (2018) verifica-se que metade da produção de hortaliças é proveniente de produtores que trabalham em 
modelo de agricultura familiar. Neste contexto, faz-se necessária a utilização de modelos de adoção pelo indivíduo.

Tang e Chen (2011), afirmam que a facilidade de uso percebida varia em diferentes modelos e organizações, considerando que há outros fatores para garantir a adoção. Neste sentido, necessita-se o aprofundamento em modelos organizacionais como o DOI e o TOE, além dos modelos de adoção de cunho individual. Entendendo as limitações dos modelos de adoção por indivíduo, o entendimento da adoção será feito tanto pelo modelo do indivíduo quanto pelo modelo organizacional. Na seção 2.4.1 serão abordados modelos de contexto individual e na seção 2.4 .2 serão abordados modelos de contexto organizacional.

\subsubsection{Modelos individuais}

Davis, Bagozzi e Warshaw (1989) em estudo sobre adoção ou não de computadores no final da década de 80, iniciaram com o TAM a abordagem dos modelos de aceitação de tecnologia, unificando modelos prévios com contextos genéricos de abordagens comportamentais e psicossociais. Um dos principais modelos que influenciou o TAM, fora o TRA, conforme visto na seção a 2.4.1.1.

\subsubsection{TRA}

O primeiro dos modelos é o Theory of Reasoned Action (TRA), em que afirmam ser oriundos de estudos psicossociais, conforme visto em Ajzen e Fishbein (1980). Neste modelo verifica-se que a composição da intenção comportamental (BI) seja atrelada a sua atitude em relação ao comportamento $(A)$ e a uma norma subjetiva (SN). Na figura 06, encontra-se o modelo TRA.

Figura 06 - Modelo TRA

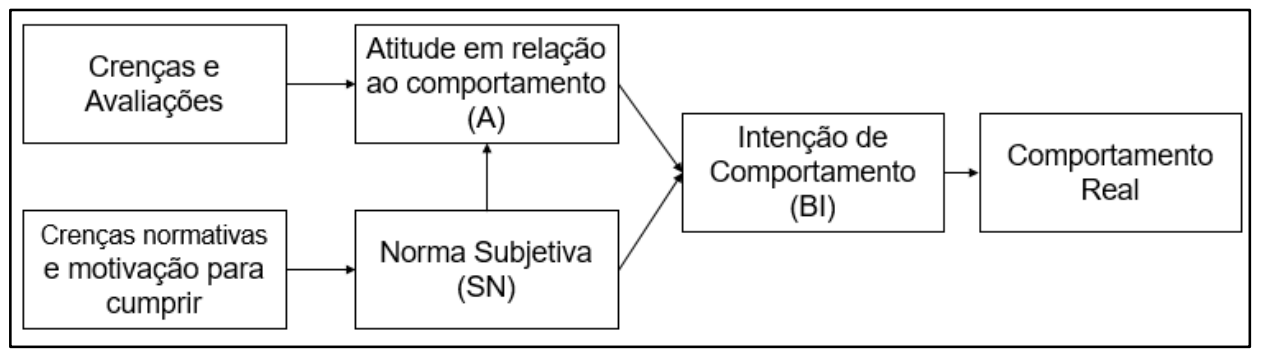

Fonte: Autor “adaptado de” Davis, Bagozzi e Warshaw, 1989, p. 984 
Apesar de poder ser aplicado na utilização de tecnologia, o TRA é um modelo genérico que busca entender o comportamento do usuário de maneira intrínseca. Para Ajzen e Fishbein (1980), o TRA pode ser influenciado por fatores externos ao indivíduo, como processos de implementação, política e estrutura organizacional.

\subsubsection{TAM}

O Modelo de Aceitação de Tecnologia (Technology Acceptance Model, TAM) é um modelo oriundo do TRA, porém voltado para questões de sistemas de informação e tecnologia. O TAM se diferencia do TRA quando coloca como pilares as questões de utilidade percebida (U) e percepção de facilidade de uso (E). Como similaridade, os dois modelos aplicam a atitude do indivíduo em relação ao sistema (A) para verificação da intenção de uso (BI) tecnologia (DAVIS; BAGOZZI; WARSHAW, 1989). Na figura 07 , segue o modelo teórico do TAM.

Figura 07 - Modelo TAM

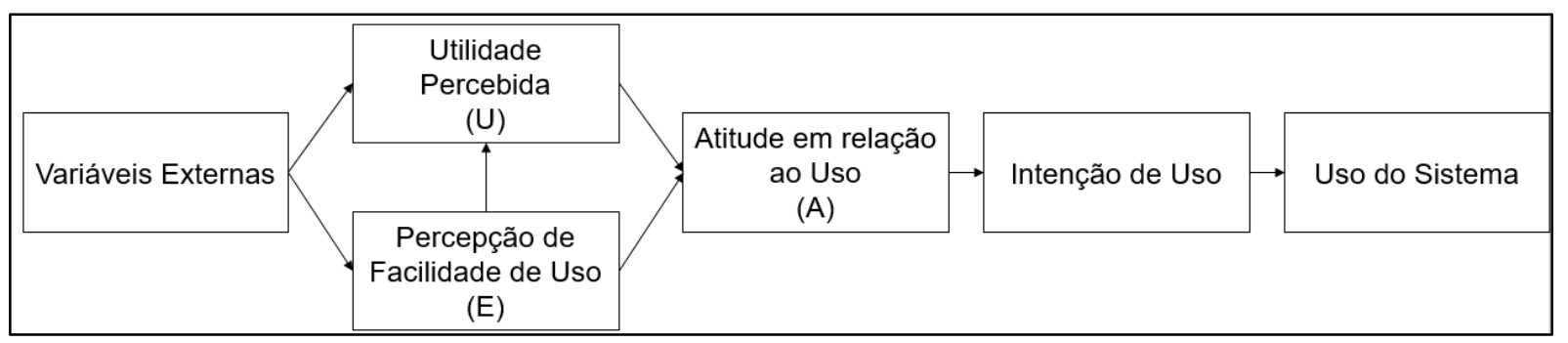

Fonte: Autor "adaptado de" Davis, Bagozzi e Warshaw, 1989, p. 985

O TAM abdica da utilização de fatores subjetivos como visto no TRA e foca seu entendimento na questão de como o usuário lida com a tecnologia (DAVIS; BAGOZZI; WARSHAW, 1989). Os autores ainda afirmam que a adoção da tecnologia pode ser voluntária por parte de gerentes e profissionais, ou imposta por superiores. Para definir a facilidade de uso $(E)$, se valeram de dois itens: Auto eficácia e Instrumentalidade. A auto eficácia é relacionada ao equipamento operar autonomamente e sua operacionalização seja relativamente simples. Já a instrumentalidade é referente a competência em operar a tecnologia.

A aplicação do TAM tangencia fatores relacionados a garantia de ganho de eficiência no processo através da adoção da tecnologia, sendo assim que a intenção 
de uso é diretamente impactada pela percepção de usabilidade enquanto se tem conhecimento ou não dos impactos da adoção, e por isso a conexão na composição do modelo.

Davis, Bagozzi e Warshaw (1989) discutem na composição do TAM as particularidades de mensurar a adoção pela facilidade de uso (EOU) ou pela utilidade percebida $(U)$. A facilidade de uso (EOU) é influenciada pelos fatores de autoeficácia e instrumentabilidade, direcionando a decisão da adoção a quesitos técnicos do uso e sua relação e a percepção de como se pode operar estes quesitos técnicos. Já a percepção de usabilidade se relaciona aos fatores de atitudes vistos no TRA, verificando que a percepção de uso passa pelo entendimento de como a tecnologia pode trazer ganhos ao processo e garantir a performance do sistema.

\subsubsection{TAM2}

Segundo Venkatesh e Davis (2000) a Extensão do Modelo de Aceitação de Tecnologia (Extendend Technology Acceptance Model, TAM2) apresenta como base - TAM junto a complementos que englobam construções teóricas adicionais ao processo de influência social e processos instrumentais cognitivos.

Como fatores de influência social, o TAM2 apresenta "Norma Subjetiva", "Voluntariedade" e "Imagem". A norma subjetiva, oriunda do TRA, é o pensamento comum a pessoas que conhecem um indivíduo e como este senso comum desencadeia no comportamento proativo ou reativo a tecnologia. Neste cenário, um indivíduo pode optar por executar um comportamento sem sua vontade própria, mas sim por acreditar que este comportamento será importante para outros indivíduos que Ihe fazem referência e influência.

Adentrando a norma subjetiva, o fator de voluntariedade e conformidade com a influência social pode impactar positivamente na intenção de uso do indivíduo. Já obrigatoriedade leva a uma maior rejeição além da influência social que recompensa ou pune o indivíduo em relação ao seu comportamento.

Ainda sobre a voluntariedade, Venkatesh e Davis (2000) propõem a internalização do uso da tecnologia. A internalização é delimitada como a introdução 
na estrutura sobre a necessidade de uma nova tecnologia e assim criar uma crença em relação ao uso. Esse processo seria realizado pelos gerentes e líderes de equipes com os colaboradores com o objetivo de criar expectativa sobre o futuro uso da tecnologia. Se feita a internalização, é possível que contextos de obrigatoriedade do uso de tecnologia ainda sejam obsorvidos positivamente pelos colaboradores.

O último fator, a imagem é descrita como um colaborador se posiciona em relação a tecnologia em um contexto social, ou seja, como mantém sua opinião sobre a tecnologia junto a outros colaboradores ou como está tecnologia agrega valor ao status de alguém. O aumento do status é a base de poder para processos de trocas sociais e a formação de coalizões, e assim garantir a intenção de uso por parte dos indivíduos.

Na figura 08 é possível verificar a esquematização do modelo.

Figura 08 - Modelo TAM2

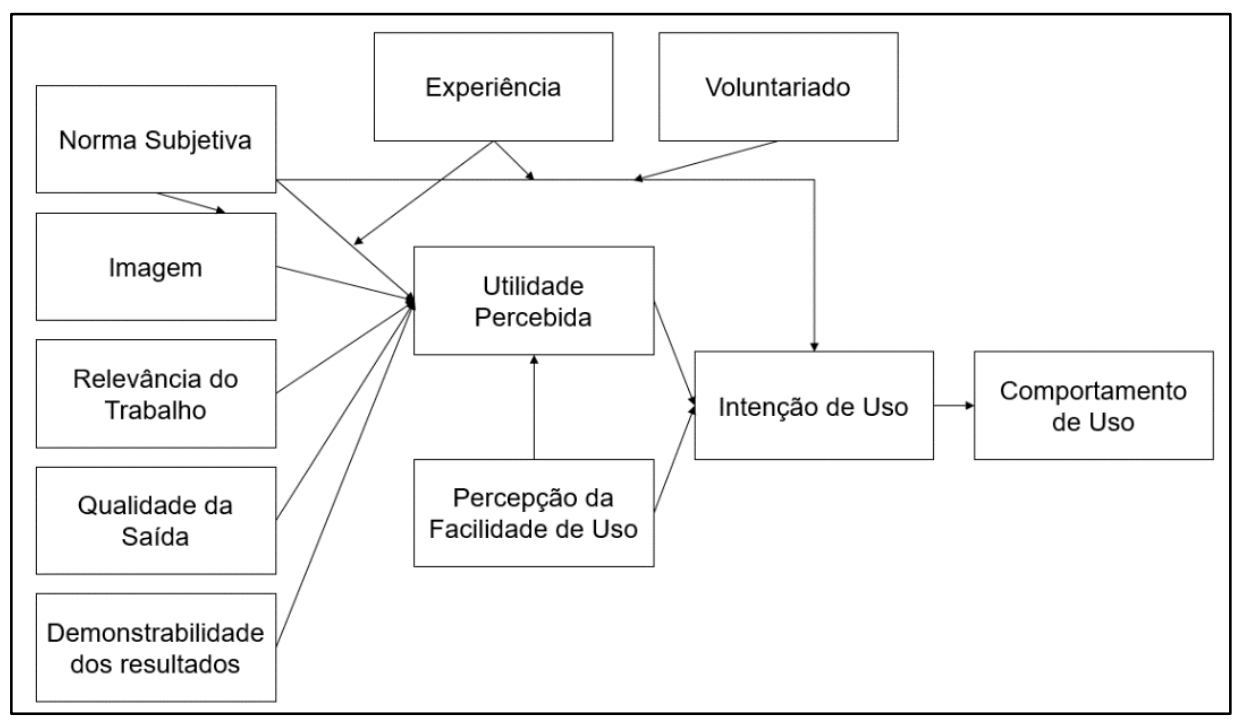

Fonte: Autor "adaptado de" Venkatesh e Davis, 2000, p. 188.

A experiência, retratada no modelo apresentado na Figura 08 é referente ao tempo de até três meses após a implementação tecnológica, na qual, os operadores e gestores já se adaptaram as forças e fraquezas da nova tecnologia e assim impactam diretamente na norma subjetiva. Antes do uso, os conceitos são vagos, por isso o fortalecimento da experiência é importante para que ao longo do tempo a norma subjetiva perca sua força e passe a existir uma percepção realista sobre a implementação. 
Por fim, Venkatesh e David (2000) definem os fatores de relevância do trabalho, qualidade da saída, demonstrabilidade dos resultados e percepção da facilidade de uso como fatores do processo instrumental cognitivo. A questão cognitiva é do indivíduo em relação a tecnologia e como esta pode impactar no seu trabalho. Desta maneira, o indivíduo com sua capacidade cognitiva projeta como este novo advento pode ou não agregar positivamente a sua própria trajetória.

Para este fator cognitivo, a relevância do trabalho é relacionada a quantidade de tarefas e como a tecnologia consegue auxiliar neste processo, ou seja, se o trabalho é significativo e se a tecnologia o impacta positivamente. Já a qualidade da saída é como o sistema ou a tecnologia performa em relação ao processo e se as saídas correspondem aos objetivos projetados, sejam eles de compatibilidade ou de rentabilidade. A demonstrabilidade dos resultados impacta diretamente a percepção de usabilidade pois a tecnologia necessita apresentar sinais de que gera ganhos de desempenho ao processo para que possa ser aceita pelos indivíduos, bem como, esta demonstrabilidade deverá ser facilmente discernível.

\subsubsection{UTAUT}

O modelo UTAUT (Unified Theory of Acceptance and Use of Technology), teoria unificada de uso e aceitação de tecnologia formulado por Venkatesh et al. (2003), é uma integração de conceitos de outros modelos de aceitação de tecnologia, dentre eles o TRA, TAM e o TAM2. Os autores projetaram também junto ao UTAUT ações proativas como treinamento e marketing a fim de direcionar os usuários a adotar e utilizar novas tencologias.

Para criar o modelo unificado, Venkatesh et al. (2003) reuniram os modelos e seus construtos em uma única tabela, sendo estes a atitude em relação ao comportamento, norma subjetiva, percepção de usabilidade, percepção de facilidade de uso, motivação intrínseca, motivação extrínseca, comportamento de controle percebido, adequação ao trabalho, complexidade, consequências de longo prazo, afeto em relação ao uso, fatores sociais, condições facilitadoras, vantagem relativa, imagem, visibilidade, compatibilidade, demonstrabilidade de resultados, voluntariedade, performance, expectativas de saída, auto eficácia e ansiedade. 
Após analisar quantitavamente os modelos, Venkatesh et al. (2003) proposuseram o UTAUT, conforme a figura 09.

Figura 09 - Modelo UTAUT

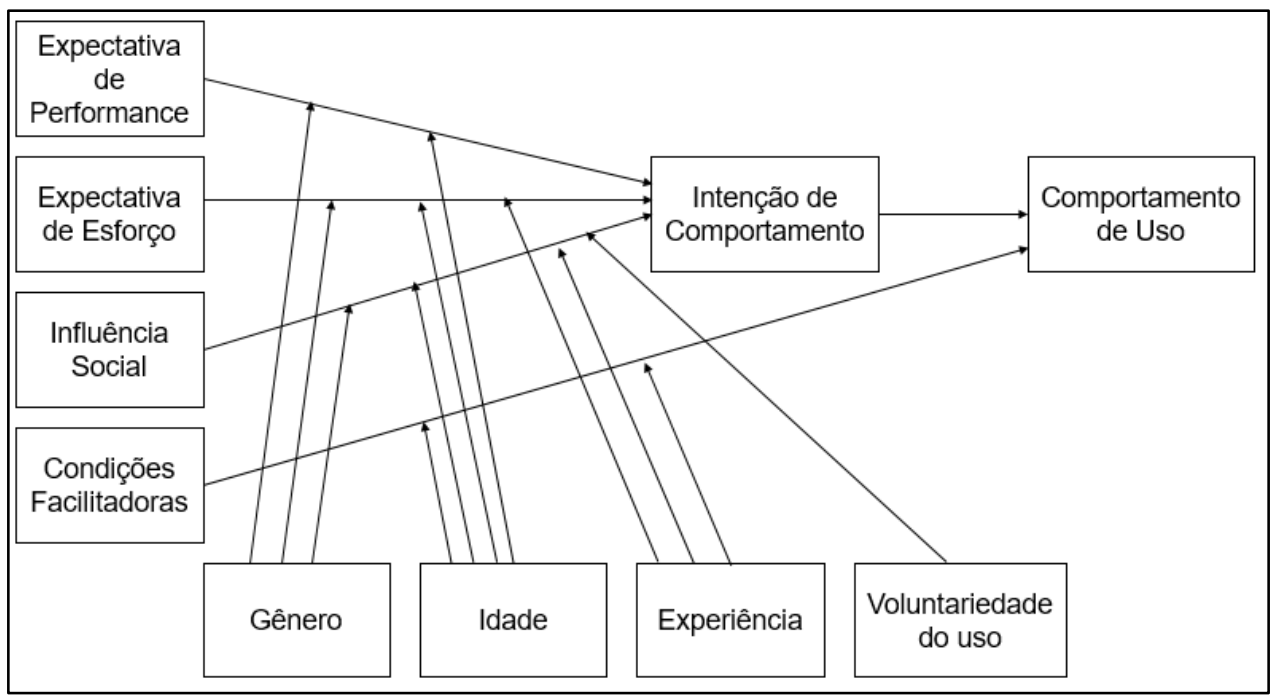

Fonte: Autor "adaptado de" Venkatesh et al., 2003, p. 447

No Quadro 04 apresentam-se as variáveis que impactam diretamente no modelo e quais construtos oriundos dos demais modelos formaram estas novas variáveis.

Quadro 04 - Variáveis e Construtos para composição do UTAUT

\begin{tabular}{|c|c|}
\hline Variável & Construtos \\
\hline Expectativa de Performance & $\begin{array}{c}\text { Utilidade percebida, motivação extrínseca, vantagem } \\
\text { relativa e expectativa de saída. }\end{array}$ \\
\hline Expectativa de Esforço & $\begin{array}{c}\text { Percepção de facilidade de uso, complexidade e } \\
\text { facilidade de uso. }\end{array}$ \\
\hline Influência Social & Norma subjetiva, fatores sociais e imagem. \\
\hline Condições Facilitadoras & $\begin{array}{c}\text { Controle comportamental percebido, condições } \\
\text { facilitadoras e compatibilidade. }\end{array}$ \\
\hline Intenção de Comportamento & Intenção de Comportamento \\
\hline Comportamento de Uso & Sem construtos (efeito direto) \\
\hline
\end{tabular}

Fonte: Autor "adaptado de" Venkatesh et al., 2003, p. 446

No Quadro 05, o modelo e suas variáveis são detalhadas. 


\section{Quadro 05 - Variáveis UTAUT}

\begin{tabular}{|c|c|c|c|c|c|}
\hline Variável & Definição & Gênero & Idade & Experiência & $\begin{array}{c}\text { Voluntariedade } \\
\text { do Uso }\end{array}$ \\
\hline $\begin{array}{l}\text { Expectativa de } \\
\text { Performance }\end{array}$ & $\begin{array}{c}\text { Grau em que } \\
\text { um indivíduo } \\
\text { acredita que o } \\
\text { uso ajudará o } \\
\text { sistema a obter } \\
\text { ganhos de } \\
\text { desempenho e } \\
\text { como } \\
\text { conseguirá } \\
\text { obter suas } \\
\text { metas mais } \\
\text { rapidamente, } \\
\text { aumentará a } \\
\text { performance, } \\
\text { ganhará em } \\
\text { produtividade e } \\
\text { terá maior } \\
\text { facilidade de } \\
\text { uso }\end{array}$ & $\begin{array}{c}\text { Mais } \\
\text { impactante aos } \\
\text { homens devido } \\
\text { a orientação a } \\
\text { tarefas }\end{array}$ & $\begin{array}{l}\text { Tendência dos } \\
\text { mais jovens } \\
\text { darem mais } \\
\text { importância às } \\
\text { recompensas } \\
\text { oriundas da } \\
\text { performance. } \\
\text { Autores } \\
\text { sugerem que a } \\
\text { idade seja } \\
\text { ponderada } \\
\text { junto ao } \\
\text { gênero. }\end{array}$ & & \\
\hline $\begin{array}{c}\text { Expectativa de } \\
\text { Esforço }\end{array}$ & $\begin{array}{c}\text { Grau de } \\
\text { facilidade em } \\
\text { utilizar o novo } \\
\text { sistema, } \\
\text { relacionado a } \\
\text { complexidade e } \\
\text { ao esforço } \\
\text { inicial do } \\
\text { processo de } \\
\text { adoção. }\end{array}$ & $\begin{array}{c}\text { Mais } \\
\text { impactante às } \\
\text { mulheres } \\
\text { devido a } \\
\text { cognições } \\
\text { relacionado aos } \\
\text { papéis de } \\
\text { gênero }\end{array}$ & $\begin{array}{l}\text { O aumento da } \\
\text { idade é } \\
\text { relacionado a } \\
\text { dificuldade de } \\
\text { assimilar } \\
\text { estímulos } \\
\text { complexos e } \\
\text { atenção a } \\
\text { novas } \\
\text { informações }\end{array}$ & $\begin{array}{c}\text { Pouco } \\
\text { experiência com } \\
\text { sistemas } \\
\text { impacta na } \\
\text { expectativa de } \\
\text { esforço }\end{array}$ & \\
\hline Influência Social & $\begin{array}{c}\text { Grau de } \\
\text { influência que } \\
\text { outros } \\
\text { indivíduos } \\
\text { relavantes } \\
\text { incidem ao } \\
\text { indivíduo } \\
\text { levando-o a } \\
\text { acreditar que } \\
\text { deve ou não } \\
\text { utilizar o novo } \\
\text { sistema. }\end{array}$ & $\begin{array}{l}\text { Mulheres } \\
\text { tendem a ser } \\
\text { mais sensíveis } \\
\text { a opiniões } \\
\text { externas e por } \\
\text { papéis de } \\
\text { gênero } \\
\text { socialmente } \\
\text { construídos }\end{array}$ & $\begin{array}{c}\text { Os mais velhos } \\
\text { tendem a ser } \\
\text { mais } \\
\text { impactados } \\
\text { pela influência } \\
\text { social, a menos } \\
\text { que tenham } \\
\text { experiência no } \\
\text { sistema. }\end{array}$ & $\begin{array}{c}\text { Indivíduos com } \\
\text { maior } \\
\text { experiência tem } \\
\text { menor impacto } \\
\text { com a influência } \\
\text { social }\end{array}$ & $\begin{array}{c}\text { Condições } \\
\text { obrigatória ou } \\
\text { voluntarias no } \\
\text { início do } \\
\text { processo de } \\
\text { adoção podem } \\
\text { impactar na } \\
\text { intenção de uso } \\
\text { do indivíduo }\end{array}$ \\
\hline $\begin{array}{l}\text { Condições } \\
\text { Facilitadoras }\end{array}$ & $\begin{array}{c}\text { Grau de } \\
\text { credibilidade } \\
\text { que o indivíduo } \\
\text { dá a } \\
\text { infraestrutura } \\
\text { para apoiar a } \\
\text { implementação } \\
\text { do novo } \\
\text { sistema. }\end{array}$ & $\begin{array}{c}\text { Os usuários } \\
\text { mais velhos são } \\
\text { mais } \\
\text { impactados } \\
\text { pela } \\
\text { infraestrutura } \\
\text { por conta de } \\
\text { suas limitações } \\
\text { físicas e } \\
\text { cognitivas }\end{array}$ & & $\begin{array}{l}\text { Quanto maior a } \\
\text { experiência } \\
\text { maior o impacto } \\
\text { da infraestrutura } \\
\text { no uso da } \\
\text { tecnologia por } \\
\text { parte do usuário } \\
\text { menor será a } \\
\text { barreira de } \\
\text { implementação }\end{array}$ & \\
\hline
\end{tabular}




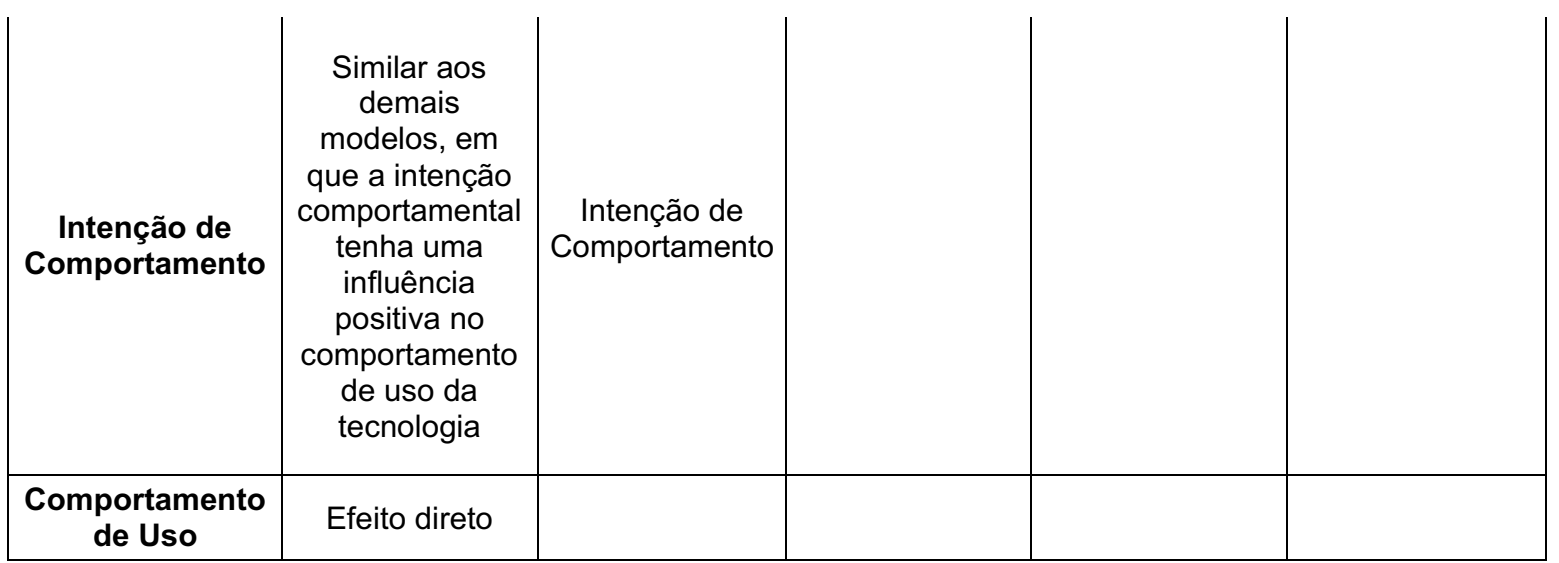

Fonte: Autor "adaptado de" Venkatesh et al., 2003, p. 446

Posteriormente, em estudo realizado por Venkatesh, Thong e Xu (2012), criouse a extensão do UTAUT, o UTAUT2 (Extension the Unified Theory of Acceptance and Use of Technology), com três novos constructos que são a motivação hedônica, valor de preço e hábito, além de desconsiderar o fator indireto da voluntariedade. Este novo formato foi pensado para alterar o contexto do usuário para o consumidor da tecnologia. A motivação hedônica é relacionada a diversão ou prazer oriundo da utilização da tecnologia, auxiliando no comportamento de compra. Já o custo é adicionado pois diferentemente dos colaboradores, os consumidores pagam pela tecnologia e o custo é um fator significativo. Por fim, o hábito é definido como o grau em que o consumidor tende a executar algum comportamento automaticamente devido ao aprendizado, ou seja, após um período de experiência e uso. O hábito é adquirido a medida que o indivíduo acredita que o seu comportamento é automático, não suprido apenas pela experiência de uso.

Por fim, referente a abordagem do UTAUT em internet of things, o estudo de Carcary et al. (2018) apresenta três grandes grupos que devem ser entendidos para a adoção desta tecnologia. No Quadro 06 segue resumo dos grupos.

Quadro 06 - UTAUT e Internet of Things

\begin{tabular}{|c|c|}
\hline EXPECTATIVA DE PERFORMANCE \\
\hline Ganho de integração e performance & \\
\hline Visibilidade de dados em tempo real & Melhorias e \\
Ganho na tomada de decisão e na análise do negócio & ganhos no aspecto \\
operacional
\end{tabular}




\begin{tabular}{|c|c|} 
Interconexão & $\begin{array}{c}\text { Pontos de atenção } \\
\text { para tornar viável a } \\
\text { adoção }\end{array}$ \\
\hline Escalabilidade & \\
\hline Serenciamento do volume de dados & \multirow{2}{*}{ Externalidades } \\
\hline Questões de segurança & \\
\hline Questões de privacidade &
\end{tabular}

Fonte: Autor "adaptado de" Carcary et al., 2018, p. 6

Com o trabalho de Carcary et al. (2018) é possível verificar que a expectativa de esforço foi negligenciada por parte dos estudos de internet of things e por este motivo não apresentou nenhum determinante. Outro ponto ressaltado pelos autores é a dificuldade da adoção de internet of things pode ser agravada por conta da tecnologia ser um sistema de sistemas e ser composto por diferentes hardwares, software e redes que ainda não foram explorados pela comunidade de pesquisa.

\subsubsection{Modelos organizacionais}

Seguindo a vertente de Tang e Chen (2011), os modelos individuais apresentam limitações referentes a incorporação de variáveis externas e da instabilidade da percepção individual. Neste sentido, faz-se necessário o estudo de modelos organizacionais como o DOI e o TOE.

Para Carcary et al. (2018), em um estudo que abrange a revisão da literatura sobre modelos de adoção aplicados a Internet of Things, comentam evidências que apontam para aplicação de modelos individuais, junto a uma aplicação de abordagem organizacional. Sugerem como pesquisas futuras a necessidade de entendimento de quais conhecimentos são necessários em esferas individuais e organizacionais para adoção de IoT. Awa, Ukoha e Emecheta (2012) complementam que a junção de modelos individuais e organizacional oferecem bases teóricas mais ricas para explicar e prever o comportamento em relação a adoção da tecnologia.

\subsubsection{DOI}

O modelo DOI (Difusion of Inovation), proposto por Rogers (1995) consiste em auxiliar na construção processo de decisão, com as etapas de conhecimento, 
persuasão, decisão, implementação e confirmação. A principal contribuição é referente a questão da comunicação e o modo como é absorvido pelo indivíduo a informação. De maneira geral, o DOI transcende o uso da tecnologia para verificar o modo de como comunicar e explicar o valor de uma inovação. A adoção da inovação ocorre na junção de cinco itens:

- Percepção dos Atributos de Inovação;

- Tipo de inovação-decisão;

- Canais de comunicação;

- Natureza do sistema social;

- Extensão dos esforços de promoção dos agentes de mudança.

O DOI centraliza seu estudo em como, por que e em que velocidade as inovações, sendo elas tecnológicas ou não, se espalham por uma organização e se disseminam em um cultura, adentrando também ao nível do indivíduo. Para esta disseminação ocorrer é necessário uma comunicação e um sistema social específico (ROGERS, 1995).

Neste modelo, como nos demais modelos já vistos anteriormente, os indivíduos possuem diferentes níveis de similaridade e proximidade às inovações. Entretanto, em um cenário macro, o conjunto de indivíduos no decorrer do tempo passa a aceitar e utilizar a inovação, até que esta caia desuso, conforme uma curva normal (ROGERS, 1995).

Adentrando na análise do indivíduo, a distribuição normal desencadeia em cinco diferentes grupos, que são os inovadores, primeiros precoces, maioria precoce, maioria tardia e retardatários. O processo de inovação, que envolve diversas fases e geralmente é complexo, deriva de apoiantes e oponentes que se relacionam a características individuais (como por exemplo liderança), a características estruturais organizacionais internas e características externas da organização (ROGERS, 1995).

Primeiramente as características individuais são correlacionadas à atitude do líder em relação a inovação. Já as características estruturais organizacionais internas incluem a centralização do controle, a contenção da complexidade através de membros da organização altamente capacitados, a padronização através da formalização de regras e procedimentos, a interconectividade através de sistemas e 
redes de pessoas interligadas, a disponibilidade de recursos, o tamanho e número de funcionários da organização. Por fim, as características externas referem-se a abertura do sistema e suas conexões (ROGERS, 1995).

\subsubsection{TOE}

O modelo de adoção de tecnologia TOE, conhecido como TechnologyOrganization-Environment, tem sido amplamente utilizado para estudos referentes a tecnologias como loT, RFID's e Cloud Computing (LIN; LEE; LIN, 2016; MASOOD; EGGER, 2019). O modelo é utilizado para definir os fatores que influenciam a adoção de tecnologia em uma organização, sendo mais abrangente por contar com fatores tecnológicos, organizacionais e ambientais (TORNATZKY; FLEISCHER, 1990).

Para Oliveira e Martins (2011) o TOE é consistente com o modelo DOI, sendo similares na abordagem tecnológica e organizacional, porém sendo o TOE mais abrangente por trazer um contexto ambiental que apresenta restrições e oportunidades a adoção da tecnologia.

O contexto tecnológico refere-se às tecnologias aplicáveis a uma organização, sendo elas internas (já em uso na organização) ou externas (disponíveis no mercado) (LIN; CHEN, 2012). O contexto organizacional refere-se às características do negócio, tais como o escopo, tamanho, confiança, estrutura gerencial, prontidão tecnológica, a qualidade dos recursos humanos e a quantidade de recursos disponíveis nos negócios. O contexto ambiental engloba o mercado que a empresa opera, os seus concorrentes e as relações e práticas do governo (GUTIERREZ; BOUKRAMI; LUMSDEN, 2015).

Na figura 10, segue estrutura do modelo TOE:

Figura 10 - Estrutura Modelo TOE 


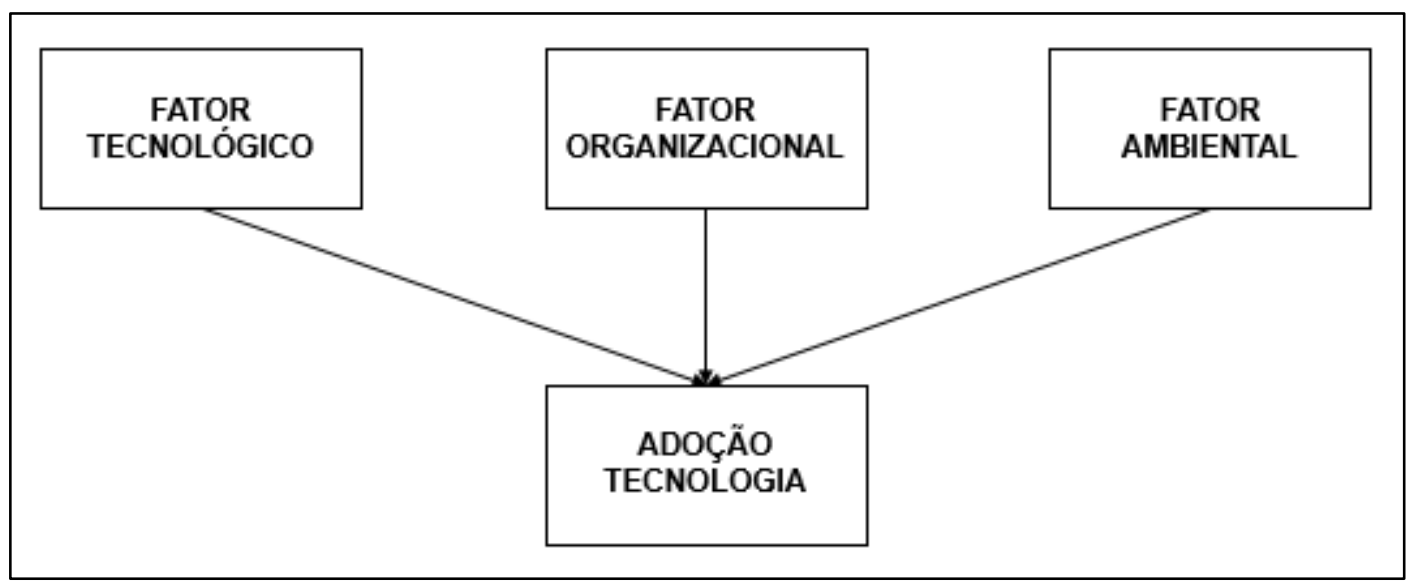

Fonte: Autor "adaptado de" Tornatzky e Fleischer, 1990, p. 27

Segundo Tornatzky e Fleischer (1990) para examinar a questão da adoção de uma inovação em uma organização deve-se se decidir em qual nível hierárquicosocial o estudo se concentrará, pois raramente a inovação é propriedade de todo o sistema.

A inovação tecnológica envolve diversas atividades, decisões e um conjunto de comportamentos por parte de indivíduos e grupos, dos quais alguns não são cientes de fazer parte desse processo. Neste cenário, sugere-se que avalie os papéis de indivíduos como indivíduos, indivíduos desempenhando papéis sociais, grupos sociais, organizações, links entre organizações, agregados de organizações e sociedades (TORNATZKY; FLEISCHER, 1990).

Desde a geração inicial da ideia até o uso da inovação tecnológica por parte dos usuários, o tempo pode variar de meses até décadas a depender da pressão ambiental exercida por uma comunidade, a qual tem o poder de acelerar o processo geral de adoção da tecnologia. Além deste fator ambiental, não se pode esquecer a atenção à organização e aos indivíduos e grupos que a compõem e por fim, não se pode ignorar as implicações da inovação para o sistema maior no qual está incorporado (TORNATZKY; FLEISCHER, 1990).

Um dos pontos importantes para garantir a adoção da tecnologia é conhecer as características pessoais dos indivíduos, independentemente do seu papel social, e sua participação em grupos e preferências. Dando um passo em relação ao indivíduo, se encontram os grupos. Geralmente a criação de grupos tende a se distanciar de questões de inovação tecnológica em si, pois na maioria das vezes são informais e 
não legitimados. Em processos de tomada de decisão em relação a tecnologia, há menos preocupação com os grupos do que com a dinâmica organizacional (TORNATZKY; FLEISCHER, 1990).

Por fim, encontram-se as organizações que, diferente dos grupos e indivíduos, apresentam diferenças significativas na esfera psicológica, social e econômica. Indivíduos e pequenos grupos apresentam diferentes tipos psicológicos, porém apresentam no geral o mesmo discurso, diferentemente das organizações. As perspectivas individuais e grupais são relacionadas ao comportamento das mesmas pessoas, nos mesmos lugares. O uso de diferentes abordagens e conjuntos de suposições orientadoras sobre o indivíduo e seu comportamento pode resultar em análises diferentes. Neste cenário é importante entender como a perspectiva e o ambiente afetam a análise (TORNATZKY; FLEISCHER, 1990).

O ambiente organizacional e a relação entre diferentes grupos são similares a uma relação comercial, dado que cada área tem sua responsabilidade e conexão com demais áreas, que muitas vezes se sobrepõem a inovação tecnológica. Tornatzsky e Fleischer (1990) sugerem como exemplo, a relação entre a equipe de desenvolvimento e pesquisa e a equipe de implementação da inovação.

O ambiente econômico é o nível mais alto que a organização opera, em que os economistas tentam enquadrar as mudanças tecnológicas à modelos tradicionais e maximizar as vantagens entre os "inputs" e "outputs". Os economistas assumem a perspectiva hiper-racional por parte das empresas, enquanto analistas sociais/organizacionais assumem a inovação tecnológica sobre sua própria perspectiva (TORNATZKY; FLEISCHER, 1990).

Por fim, no ambiente externo à organização se encontram influências em larga escala, como as forças de mercado e políticas sociais, que afetam a tomada de decisão da organização e de seus pares. Dentre este ambiente se encontram regulamentações tributárias, práticas regulatórias, leis, políticas de patentes e o apoio do governo. Outras práticas governamentais e investimentos em educação podem impactar no fornecimento de pessoas e recursos às organizações (TORNATZKY; FLEISCHER, 1990). Alhogail (2018) comenta que variações de regulamentações 
governamentais em cada região podem afetar o modelo e sugere que os limites de investigação sejam realizados em mais de uma região.

Oliveira e Martins (2011) adaptando Tornatzky e Fleischer, propõem que o modelo seja sustentado pelos seguintes fatores:

- Fator Tecnológico: Disponibilidade e características tecnológicas;

- Fator Organizacional: Laços formais e informais na estrutura organizacional, comunicação entre processos e tamanho da organização

- Fator Ambiental: Características da indústrias, estrutura de mercado, infraestrutura tecnológica e regulamentação governamental.

Alguns estudos utilizaram o modelo para aplicação em tecnologias emergentes, como o caso do estudo de Gutierrez, Boukrami e Lumsden (2015) que utilizaram o TOE para estudar a adoção de Cloud Computing. Abaixo segue os constructos do modelo que utilizaram:

- Fator tecnológico: Vantagem relativa, complexidade e compatibilidade;

- Fator Organizacional: Apoio da alta administração, tamanho da organização e tecnologia já implantada;

- Fator Ambiental: Pressão competitiva e pressão dos parceiros comerciais;

Como conclusão, verificaram que o fator mais significativo para adoção de Cloud Computing fora o fator ambiental, sendo este o que mais contribuiu com barreiras e alavancas ao processo de adoção.

Sun et al. (2016) em estudo sobre big data propuseram a seguinte composição de variáveis para o TOE:

- Fatores Tecnológicos: Vantagem relativa, custo da adoção, complexidade, compatabilidade, confiabilidade e observabilidade;

- Fatores Organizacionais: Recursos humanos, suporte gerencial, recursos tecnológicos, cultura para tomada de decisões, estratégia de negócio, estrutura organizacional e tamanho da organização;

- Fatores Ambientais: Segurança, privacidade, ética na obtenção de dados, parceiros comerciais, regulamentação, turbulência do mercado e confiança institucional. 
No que tange a aplicação do TOE na análise da adoção de Internet of Things, o estudo de Lin, Lee e Lin (2016) utilizou as seguintes variáveis:

- Fator Tecnológico: Complexidade, compatibilidade, benefício percebido e custo;

- Fator Organizacional: Escala da empresa, suporte executivo, relações entre empresas na cadeia de fornecimento, conhecimento técnico e resistência interna;

- Fator Ambiental: Pressão externa, incerteza e apoio do governo.

Para Namisiko, Munialo e Nyongesa (2014), os fatores foram distribuidos da seguinte maneira:

- Fator Tecnológico: Custo, confiabilidade, compatibilidade, complexidade e expectativa de desempenho;

- Fator Organizacional: Recursos humanos, recursos financeiros, inovação e competitividade;

- Fator Ambiental: Indústrias, concorrência, governo, fornecedores e clientes;

Já Baker (2011), afirma que o TOE pode ser utilizado para análises em sistemas interorganizacionais, e-business, intercâmbio eletrônico de dados (EDI), sistemas abertos e sistemas corporativos. 


\section{QUADRO TEÓRICO}

AlHogail (2018) em estudo sobre a incerteza e confiança do usuário e do consumidor em adotar Internet of Things, verificou que é necessária a especificação de novos domínios de aplicação da tecnologia. Neste mesmo estudo, os autores utilizaram modelos de aceitação e modelos psicossociais, e sintetizaram que é necessária a consideração de fatores culturais e governamentais, além de expandir o estudo à outras comunidades.

Como visto na seção 2.4.2, para Carcary et al. (2018) há evidências da utilização de modelos de adoção individuais junto a modelos de adoção organizacionais. Ainda no mesmo estudo, comentam que projetam o uso do modelo UTAUT junto a modelos organizacionais. Dos modelos organizacionais abordados, o que mais tem sido utilizado no contexto de internet of things é o modelo TOE, além de ser mais completo por apresentar o fator ambiental, que agrega barreiras ou alavancas ao processo de adoção de tecnologia (SUN et al., 2016). Neste sentido, este estudo agregará em um modelo único os construtos dos modelos TOE e UTAUT, direcionando a abordagem da adoção de internet of things.

Choudrie e Dwivedi (2005), em uma revisão sobre os modelos de adoção de tecnologia, verificaram que dos estudos conduzidos, apenas dois métodos foram empregados, o survey em $74 \%$ das publicações e o estudo de caso em $26 \%$ das publicações. Segundo o mesmo estudo, o método estudo de caso fora empregado para modelos organizacionais, sendo este o método mais adequado para contextos que transcedem a aplicação do modelo de adoção no usuário.

No Quadro 07 seguem os fatores provenientes dos modelos TOE e UTAUT para composição do quadro teórico e suas respectivas variáveis, com objetivo de entender a adoção de internet of things.

Quadro 07 - Quadro Teórico

\begin{tabular}{|c|c|c|}
\hline FATOR & VARIÁVEL & REFERÊNCIA \\
\hline \multirow{4}{*}{ Comportamental } & Expectativa de Performance & VENKATESH et al., 2003 \\
\cline { 2 - 3 } & Expectativa de Esforço & VENKATESH et al., 2003 \\
\cline { 2 - 3 } & Influência Social & VENKATESH et al., 2003 \\
\cline { 2 - 3 } & Condições Facilitadoras & VENKATESH et al., 2003 \\
\hline
\end{tabular}




\begin{tabular}{|c|c|c|}
\hline Tecnológico & Custo & $\begin{array}{l}\text { SUN et al., 2016; NAMISIKO; } \\
\text { MUNIALO; NYONGESA, } 2014\end{array}$ \\
\hline Tecnológico & Disponibilidade & OLIVEIRA; MARTINS, 2011; \\
\hline Organizacional & $\begin{array}{c}\text { Tamanho e Estrutura da } \\
\text { Empresa }\end{array}$ & $\begin{array}{l}\text { OLIVEIRA; MARTINS, 2011; } \\
\text { GUTIERREZ; BOUKRAMI; } \\
\text { LUMSDEN, 2015; SUN et al. } \\
\text { 2016; LIN; LEE; LIN, } 2016\end{array}$ \\
\hline Ambiental & Pressão competitiva & $\begin{array}{l}\text { GUTIERREZ; BOUKRAMI; } \\
\text { LUMSDEN, 2015; NAMISIKO; } \\
\text { MUNIALO; NYONGESA, } 2014 \\
\text { SUN et al. 2016; }\end{array}$ \\
\hline Ambiental & $\begin{array}{l}\text { Apoio do Governo e } \\
\text { Regulamentação }\end{array}$ & $\begin{array}{l}\text { OLIVEIRA; MARTINS, 2011; } \\
\text { SUN et al. 2016; LIN; LEE; } \\
\text { LIN, 2016; NAMISIKO; } \\
\text { MUNIALO; NYONGESA, } 2014\end{array}$ \\
\hline
\end{tabular}

Fonte: Autor

Com estas informações, propôs-se o modelo teórico na Figura 11.

Figura 11 - Modelo Proposto

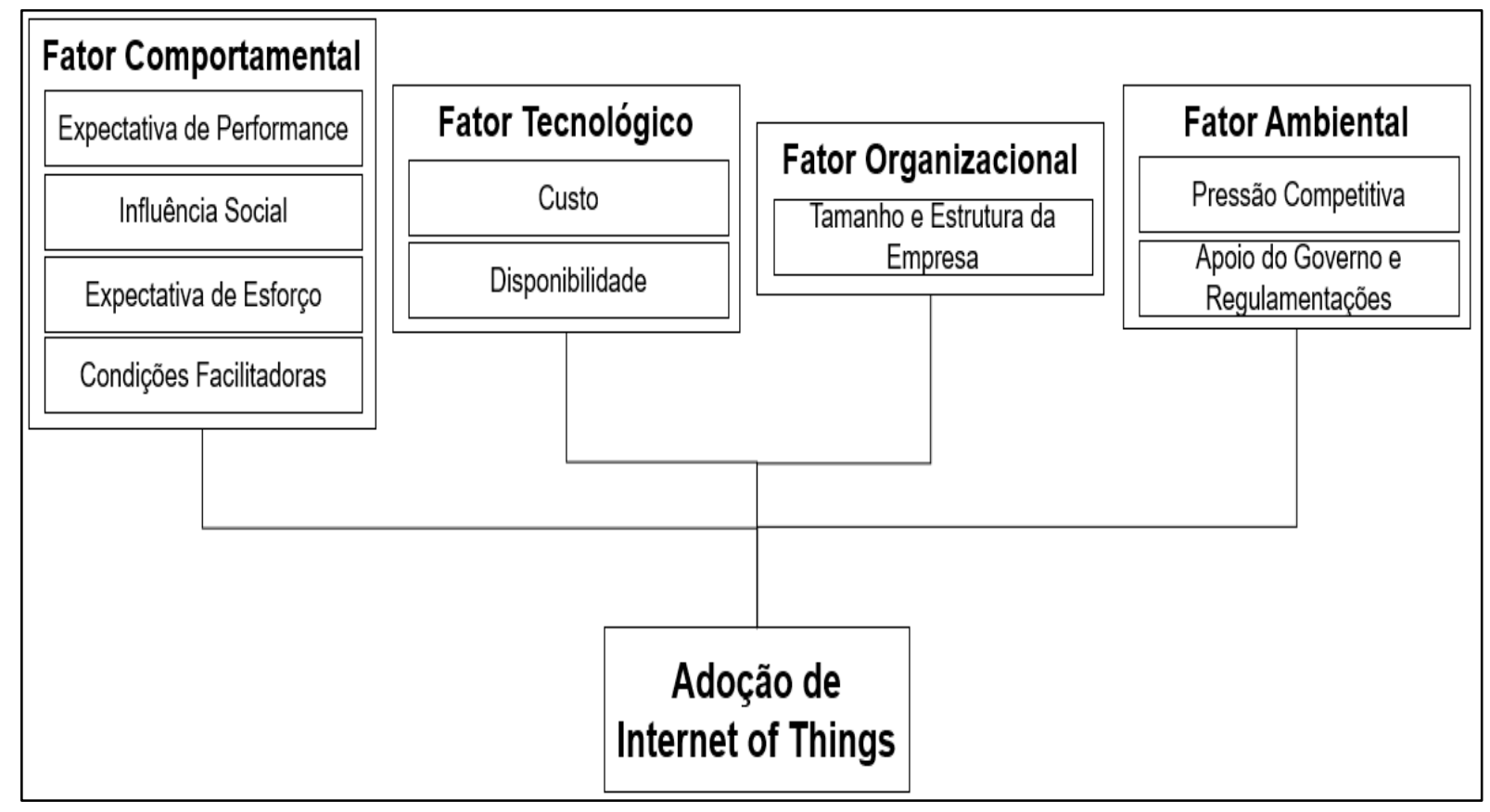

Fonte: Autor, 2020

Nas próximas seções serão detalhados os construtos do modelo e como eles serão abordados no estudo de caso do plantío de hortaliças. 


\subsection{FATOR COMPORTAMENTAL}

O fator comportamental corresponde a última variável do modelo UTAUT, o "comportamento de uso". As variáveis auxiliares "gênero", "idade" e "experiência" do modelo UTAUT ficaram em um segundo plano de análise, pois são utilizadas no contexto de estudos quantitativos, diferente da abordagem qualitativa adotada neste estudo.

Neste fator foram verificadas variáveis similares em alguns estudos relacionados a adoção de tecnologia e que foram concentrados da seguinte maneira no Quadro 08.

Quadro 08 - Fator Comportamental

\begin{tabular}{|c|c|}
\hline \multicolumn{2}{|r|}{ FATOR COMPORTAMENTAL } \\
\hline $\begin{array}{l}\text { Expectativa de } \\
\text { Performance }\end{array}$ & $\begin{array}{c}\text { Vantagem Relativa (GUTIERREZ; BOUKRAMI; } \\
\text { LUMSDEN, 2015; SUN et al. 2016), Benefício } \\
\text { Percebido (LIN; LEE; LIN, 2016), Expectativa de } \\
\text { Desempenho (NAMISIKO; MUNIALO; NYONGESA, } \\
\text { 2014), Integração, Performance, Eficiência } \\
\text { Organizacional e Produtividade (CARCARY et al., 2018) }\end{array}$ \\
\hline Expectativa de Esforço & $\begin{array}{c}\text { Complexidade (GUTIERREZ; BOUKRAMI; LUMSDEN, } \\
\text { 2015; SUN et al. 2016; NAMISIKO; MUNIALO; } \\
\text { NYONGESA, 2014) }\end{array}$ \\
\hline Influência Social & \\
\hline Condições Facilitadoras & $\begin{array}{c}\text { Compatibilidade (GUTIERREZ; BOUKRAMI; } \\
\text { LUMSDEN, 2015; SUN et al. 2016), Interconexão, } \\
\text { Escalabilidade, Gerenciamento dos Dados e Suporte } \\
\text { Organizacional (CARCARY et al., 2018) }\end{array}$ \\
\hline
\end{tabular}

Fonte: Autor

A primeira variável do fator comportamental é a expectativa de performance, que é relacionada ao grau que o usuário acredita que ganhará em desempenho e vantagem competitiva com o uso de internet of things. Neste item será verificado como o indivíduo acredita que a tecnologia acrescentará em qualidade, produtividade e controle ao processo já implementado. Abaixo, as proposições para esta variável.

- A expectativa de performance impacta na adoção de internet of things no plantio de hortaliças. 
A segunda variável é a expectativa de esforço, que será analisada com base na complexidade enxergada pelo usuário para implementar internet of things. Neste sentido, a proposição para esta variável é vista a seguir.

- A complexidade impacta na adoção de internet of things no plantio de hortaliças.

Já a influência social será analisada com base na voluntariedade de uso, similar ao que é proposto no modelo UTAUT. Segundo Carcary et al. (2018) esta é a variável menos explorada nos estudos sobre adoção de internet of things, explicitando a necessidade de entendimento no contexto do plantio de hortaliças. O objetivo é verificar se as opiniões de indivíduos que fazem referência ao produtor impactam na intenção de adoção de loT. Assim, a proposição será:

- A influência social impacta na adoção de loT no plantio de hortaliças.

Por fim, as condições facilitadoras agregam a percepção do produtor sobre como sua infraestrura de internet, equipamentos, tempo, tamanho ou método de trabalho impactam na possível implementação de loT. A proposição será:

- As condições tecnológicas do produtor impactam na adoção de internet of things no plantio de hortaliças.

\subsection{FATOR TECNOLÓGICO}

Alguns construtos do fator tecnológico foram alocados no fator comportamental, pois são necessários no entendimento do usuário e como este projeta o seu uso. Neste fator vislumbra-se entender como a tecnologia em si pode ser uma barreira ou habilitador e como o produtor interpreta a sua adoção.

A seguir algumas proposições com base no custo e disponibilidade.

- Os custos de implementação da tecnologia impactam na adoção de internet of things no plantio de hortaliças;

- A disponibilidade da tecnologia impacta na adoção de internet of things no plantio de hortaliças. 


\subsection{FATOR ORGANIZACIONAL}

Este fator tem como objetivo entender como a estrutura a qual se encontra o produtor e seu plantío pode impactar ou não na adoção de loT. Neste sentido, o tamanho da organização é fundamental para verificar se produtores familiares, que são a maior parte dos agricultores brasileiros, têm dificuldades em adotar internet of things. Relacionados a este fator, foram verificadas em Namisiko, Munialo e Nyongesa (2014) variáveis relacionadas a inovação e em Lin, Lee, Lin (2016) variáveis relacionadas a resistência interna, que devem ser compreendidas no contexto do tamanho e estrutura da empresa.

Neste contexto, seguem as proposições.

- O tamanho do produtor impacta na adoção de internet of things no plantio de hortaliças;

- A estrutura organizacional e a cultura do produtor impactam na adoção de internet of things no plantio de hortaliças.

\subsection{FATOR AMBIENTAL}

O fator ambiental abordará influências externas ao produtor e que não podem ser diretamente modificadas. O objetivo é verificar como o cenário em que o produtor está inserido impacta na adoção de internet of things no plantío de hortaliças. As proposições são:

- A pressão competitiva impacta na adoção de internet of things no plantio de hortaliças;

- Os incentivos do governo impactam na adoção de internet of things no plantio de hortaliças;

- A regulamentação relacionada ao plantio de hortaliças impacta na adoção de internet of things.

Na seção seguinte encontra-se quadro com resumo das proposições a serem discutidas no estudo. 


\subsection{PROPOSIÇÕES}

No Quadro 09 segue o resumo de proposições para os fatores elencados e referenciados na seção 3 .

Quadro 09 - Proposições

\begin{tabular}{|c|c|}
\hline Construtos & Proposição \\
\hline $\begin{array}{l}\text { Expectativa de } \\
\text { Performance }\end{array}$ & $\begin{array}{l}\text { A expectativa de performance impacta na adoção de internet } \\
\text { of things no plantio de hortaliças }\end{array}$ \\
\hline Complexidade & $\begin{array}{l}\text { A complexidade impacta na adoção de internet of things no } \\
\text { plantio de hortaliças }\end{array}$ \\
\hline Influência Social & $\begin{array}{c}\text { A influência social impacta na adoção de loT no plantio de } \\
\text { hortaliças }\end{array}$ \\
\hline Condições Facilitadoras & $\begin{array}{l}\text { As condições tecnológicas do produtor impactam na adoção } \\
\text { de internet of things no plantio de hortaliças }\end{array}$ \\
\hline Custo & $\begin{array}{l}\text { Os custos de implementação da tecnologia impactam na } \\
\text { adoção de internet of things no plantio de hortaliças }\end{array}$ \\
\hline Disponibilidade & $\begin{array}{c}\text { A disponibilidade da tecnologia impacta na adoção de internet } \\
\text { of things no plantio de hortaliças }\end{array}$ \\
\hline \multirow{2}{*}{$\begin{array}{l}\text { Tamanho e Estrutura da } \\
\text { Empresa }\end{array}$} & $\begin{array}{c}\text { O tamanho do produtor impacta na adoção de internet of } \\
\text { things no plantio de hortaliças }\end{array}$ \\
\hline & $\begin{array}{l}\text { A estrutura organizacional e a cultura do produtor impactam } \\
\text { na adoção de internet of things no plantio de hortaliças }\end{array}$ \\
\hline Pressão Competitiva & $\begin{array}{c}\text { A pressão competitiva impacta na adoção de internet of } \\
\text { things no plantio de hortaliças }\end{array}$ \\
\hline \multirow{2}{*}{$\begin{array}{l}\text { Apoio do Governo e } \\
\text { Regulamentações }\end{array}$} & $\begin{array}{c}\text { Os incentivos do governo impactam na adoção de internet of } \\
\text { things no plantio de hortaliças }\end{array}$ \\
\hline & $\begin{array}{l}\text { A regulamentação relacionada ao plantio de hortaliças } \\
\text { impacta na adoção de internet of things }\end{array}$ \\
\hline
\end{tabular}

Fonte: Autor

No Quadro 10, segue resumo de quatro pesquisas relacionadas a adoção de tecnologia, que discutiram as variáveis propostas neste estudo, evidenciando a necessidade de compreendê-las sob a ótica qualitativa e no contexto do plantio de hortaliças. 
Quadro 10 - Estudos Similares

\begin{tabular}{|c|c|c|c|c|}
\hline \multirow[b]{2}{*}{ Construtos } & \multicolumn{3}{|c|}{ HIPÓTESES } & \multirow{2}{*}{$\begin{array}{l}\text { PROPOSIÇÃO } \\
\text { Sun et al. (2016) } \\
\text { no contexto de } \\
\text { Big Data }\end{array}$} \\
\hline & $\begin{array}{c}\text { ALHOGAIL (2018) } \\
\text { no contexto de } \\
\text { loT }\end{array}$ & $\begin{array}{c}\text { GUTIERREZ, } \\
\text { BOUKRAMI E } \\
\text { LUMSDEN (2015) } \\
\text { no contexto de } \\
\text { Cloud Computing }\end{array}$ & $\begin{array}{c}\text { MASOOD e } \\
\text { EGGER (2019) no } \\
\text { contexto de } \\
\text { Realidade } \\
\text { Aumentada }\end{array}$ & \\
\hline $\begin{array}{l}\text { Expectativa de } \\
\text { Desempenho }\end{array}$ & $\begin{array}{l}\text { A utilidade } \\
\text { percebida tem um } \\
\text { forte efeito sobre } \\
\text { a confiança na } \\
\text { adoção de loT }\end{array}$ & $\begin{array}{c}\text { A vantagem relativa } \\
\text { influencia a adoção } \\
\text { da computação em } \\
\text { nuvem em relação } \\
\text { ao esforço para } \\
\text { mudança }\end{array}$ & & \\
\hline Complexidade & $\begin{array}{c}\text { A facilidade de } \\
\text { uso percebida } \\
\text { tem um efeito } \\
\text { significativo na } \\
\text { confiança em } \\
\text { relação à adoção } \\
\text { de loT }\end{array}$ & $\begin{array}{l}\text { Complexidade } \\
\text { influencia a } \\
\text { adoção da } \\
\text { computação em } \\
\text { nuvem levando } \\
\text { em conta a } \\
\text { compatibilidade } \\
\text { do processo atual }\end{array}$ & & \\
\hline Influência Social & $\begin{array}{l}\text { O interesse da } \\
\text { comunidade } \\
\text { influencia } \\
\text { positivamente a } \\
\text { confiança na } \\
\text { adoção de loT }\end{array}$ & $\begin{array}{l}\text { O suporte da alta } \\
\text { gerência } \\
\text { influencia a } \\
\text { adoção da } \\
\text { computação em } \\
\text { nuvem }\end{array}$ & $\begin{array}{c}\text { A barreira do } \\
\text { usuário está } \\
\text { associada } \\
\text { negativamente ao } \\
\text { sucesso da } \\
\text { implementação } \\
\text { dos sistemas de } \\
\text { RA }\end{array}$ & \\
\hline $\begin{array}{l}\text { Condições } \\
\text { Facilitadoras }\end{array}$ & & $\begin{array}{c}\text { A compatibilidade } \\
\text { influencia a adoção } \\
\text { da computação em } \\
\text { nuvem impactando } \\
\text { na resistencia a } \\
\text { mudança por parte } \\
\text { dos gerentes }\end{array}$ & $\begin{array}{c}\text { A compatibilidade } \\
\text { da tecnologia está } \\
\text { positivamente } \\
\text { associada ao } \\
\text { sucesso da } \\
\text { implementação } \\
\text { dos sistemas de } \\
\text { RA. }\end{array}$ & \\
\hline Custo & & & & $\begin{array}{c}\text { Possíveis } \\
\text { despesas } \\
\text { relacionadas à } \\
\text { adoção de big } \\
\text { data }\end{array}$ \\
\hline Disponibilidade & & $\begin{array}{c}\text { A prontidão } \\
\text { tecnológica } \\
\text { influencia a } \\
\text { adoção da } \\
\text { computação em } \\
\text { nuvem }\end{array}$ & $\begin{array}{l}\text { A prontidão da } \\
\text { tecnologia está } \\
\text { positivamente } \\
\text { associada ao } \\
\text { sucesso de } \\
\text { sistemas de RA. }\end{array}$ & \\
\hline
\end{tabular}




\begin{tabular}{|c|c|c|c|}
\hline $\begin{array}{c}\text { Tamanho e } \\
\text { Estrutura da } \\
\text { Empresa }\end{array}$ & $\begin{array}{c}\text { Tamanho da } \\
\text { empresa } \\
\text { influencia a } \\
\text { adoção da } \\
\text { computação em } \\
\text { nuvem }\end{array}$ & $\begin{array}{l}\text { A estrutura } \\
\text { organizacional } \\
\text { está associada } \\
\text { positivamente ao } \\
\text { sucesso de } \\
\text { sistemas de RA. }\end{array}$ & \\
\hline $\begin{array}{l}\text { Pressão } \\
\text { Competitiva }\end{array}$ & $\begin{array}{c}\text { Pressão } \\
\text { competitiva } \\
\text { influencia a } \\
\text { adoção da } \\
\text { computação em } \\
\text { nuvem }\end{array}$ & & \\
\hline $\begin{array}{c}\text { Apoio do Governo } \\
\text { e } \\
\text { Reguamentações }\end{array}$ & & & $\begin{array}{l}\text { As agências } \\
\text { governamentais } \\
\text { incentivam as } \\
\text { empresas a } \\
\text { adotar big data, } \\
\text { fornecendo } \\
\text { suporte } \\
\text { relacionado (por } \\
\text { exemplo, } \\
\text { ambiente legal, } \\
\text { regulamentação } \\
\text { do setor, } \\
\text { regulamentação } \\
\text { de proteção de } \\
\text { dados). }\end{array}$ \\
\hline
\end{tabular}

Para verificar a veracidade das proposições e discutir as variáveis apresentadas, na seção 4 é detalhada a metodologia utilizada na pesquisa. 


\section{METODOLOGIA}

A pesquisa é um processo que busca a investigação de problemas teóricos ou práticos por meio métodos científicos. Sendo assim, o método é a ordenação que se deve impor para atingir o objetivo do estudo (CERVO; BERVIAN; SILVA, 2006). Neste contexto, este trabalho tem como natureza uma pesquisa qualitativa exploratória, com a utilização do método de estudo de multi-casos.

\subsection{MÉTODO}

A natureza qualitativa, segundo Cauchick et al. (2010), é a ênfase na perspectiva do indivíduo que está sendo estudado, no qual o objetivo maior é interpretar o ambiente da pesquisa no qual o indivíduo está inserido. Uma das características é a subjetividade dos envolvidos, podendo interferir na construção do resultado da pesquisa. Como indivíduos podem ser considerados desde trabalhadores, até diretores e outros profissionais.

Cervo, Bervian e Silva (2006), a pesquisa exploratória é o primeiro passo para o entendimento de um determinado assunto, no qual se formula hipóteses significativas para alavancar futuras pesquisas. O objetivo é realizar descrições de determinadas situações e descobrir relações entre os elementos componentes da pesquisa. Para Gil (2002) pesquisas exploratórias devem proporcionar maior familiaridade com o problema e torná-lo mais explícito. Na maioria dos casos são obtidos através de levantamentos bibliográficos, entrevistas e análise de exemplos.

Para realizar esta proximidade com o tema, o estudo de caso é uma modalidade adequada para o estudo profundo e exaustivo de um ou poucos objetivos, de maneira que permita a disseminação de conhecimento de maneira detalhada e ampla. Os estudos de casos geralmente formulam hipóteses, geram aberturas de pesquisa e trazem um contexto real da situação de um determinado assunto, porém não nas condições de conclusão. Os objetivos do estudo de caso são explorar situações da vida real, formular hipóteses ou teorias, descrever o contexto da investigação e explicar variáveis causais de um determinado fenômeno (GIL, 2002).

Ainda Gil (2002) define como etapas do estudo de caso a formulação do problema, definição da unidade-caso, determinação do número de casos, coleta de 
dados, avaliação dos dados e preparação do relatório. Na questão da determinação do número de casos, a utilização de multi-casos proporciona evidências coletadas em diferentes contextos, desencadeando uma pesquisa de melhor qualidade. Por fim, Yin (2014) afirma que o estudo de caso é o método mais adequado para descrever eventos contemporâneos.

Ketokiv e Choi (2014), em revisão sobre a utilização do método estudo de caso, buscaram direcionar os pesquisadores em meio a heterogeneidade e dualidade de critérios entre estudos qualitativos (relacionados a significado e interpretação) e quantitativos (relacionados a quantidade, frequência e intensidade). Desta maneira, elaboraram três caminhos metodológicos: geração da teoria, teste da teoria e elaboração da teoria.

Referente a dualidade, Ketokiv e Choi (2014) comentam que estudos qualitativos muitas vezes se valem de fundamentos quantitativos. Nos estudos de casos, principalmente nos multi-casos, são necessários estes fundamentos para comparar os diferentes casos e suas características. A diferença entre os estudos se dá no objetivo intrínseco ao método, em que nos estudos de casos a dimensionalidade e a medição são irrelevantes, dando maior foco a análise, ao estudo empírico e no aprofundamento do assunto estudado.

Seguindo o caminho metodológico proposto por Ketokiv e Choi (2014), compreende-se que este estudo é relacionado a teoria de teste, no qual há literatura sobre o tema em estudo, com hipóteses especifícas ao assunto e que podem ser discutidas no âmbito qualitativo. Este estudo não deriva da teoria da elaboração, pois não propõe acréscimos aos modelos já existentes, apenas os considera dentro de um quadro teório para direcionar a pesquisa. $\mathrm{Na}$ teoria de teste nega-se a necessidade do teste de hipóteses das variáveis para que elas possam ser aplicadas a determinado assunto, levando em conta testes com dados empíricos.

Por fim, conforme visto em Choudrie e Dwivedi (2005), o estudo de caso é o método mais adequado e utilizado em modelos de adoção, principalmente quando o objeto de estudo transcende à análise do usuário. Os autores ressaltam ainda que há uma gama de ferramentas para realizar o estudo, como telefonemas, entrevistas 
presenciais e questionários na web. Na seção 4.2 será detalhado o instrumento da pesquisa e os meios de obtenção de dados.

\subsection{INSTRUMENTO DA PESQUISA}

Para o entendimento do assunto da pesquisa, o trabalho utiliza como coleta de dados, a realização de entrevistas com produtores e especialistas do processo de plantio de hortaliças, com base em Cervo, Bervian e Silva (2006) que afirmam que as entrevistas têm como objetivo recolher, por meio de interrogatório informante, dados para pesquisa qualitativa, com uma orientação pré-definida. As hortaliças que são objeto do estudo são a alface, batata, cebola, cenoura e tomate, por serem as principais hortaliças, segundo a CONAB (2019).

Na seção 3 discutiu-se o modelo teórico para análise da adoção de internet of things no plantio de hortaliças e, com base neste modelo, foram geradas proposições que serão estudadas através de entrevistas, seguindo o protocolo de pesquisa presentes nos Apêndice - B e Apêndice $C$.

O instrumento de coleta de dados também encontra-se nos Apêndices B e C.

\subsection{PRODUTORES, ESPECIALISTAS E FORNECEDORES}

O presente trabalho, com o objetivo de discutir a adoção de internet of things no plantio de hortaliças, abrange entrevistas com especialistas e fornecedores (de tecnologia, insumos ou apoio consultivo), além dos próprios produtores (potenciais usuários da tecnologia), para obter uma visão holística sobre a relação da tecnologia e o segmento a partir de diferentes stakeholders. No Quadro 11 é possível verificar a distribuição dos 15 produtores entrevistados, no Quadro 12 encontram-se informações referente aos especialistas e por fim, seguem no Quadro 13 informações referentes aos fornecedores. 
Quadro 11 - Produtores Entrevistados

\begin{tabular}{|c|c|c|c|c|c|}
\hline NOME & ALFACE & BATATA & CEBOLA & CENOURA & TOMATE \\
\hline PRO1 & & & & & $\mathrm{x}$ \\
\hline PRO2 & $x$ & & & & \\
\hline PRO3 & & $x$ & $x$ & $x$ & \\
\hline PRO4 & & & & & $x$ \\
\hline PRO5 & & $x$ & & & \\
\hline PRO6 & & & $x$ & & \\
\hline PRO7 & & & $x$ & & \\
\hline PRO8 & & $x$ & $x$ & $x$ & \\
\hline PRO9 & $x$ & & & & \\
\hline PRO10 & $x$ & & & & \\
\hline PRO11 & $x$ & & & & \\
\hline PRO12 & $x$ & & & & \\
\hline PRO13 & $x$ & & $x$ & $x$ & $x$ \\
\hline PRO14 & $x$ & & & & \\
\hline PRO15 & & & & & $x$ \\
\hline
\end{tabular}

Fonte: Autor

Quadro 12 - Especialistas Entrevistados

\begin{tabular}{|c|c|}
\hline NOME & DESCRIÇÃO \\
\hline \multirow{1}{*}{ ESP1 } & $\begin{array}{c}\text { Possui graduação em Agronomia pela Universidade Federal de Santa } \\
\text { Maria (2007). Mestre em Agronomia pela Universidade de Brasília } \\
\text { (2009), com ênfase em Sistemas Agrícolas de Produção Sustentável. } \\
\text { Desde 2009 é Técnico A da Empresa Brasileira de Pesquisa } \\
\text { Agropecuária (Embrapa) atuando na Área Transferência de Tecnologia, } \\
\text { trabalhando com Articulação Técnica, Instalação de Unidades } \\
\text { Demonstrativas, Cursos, Capacitaçães, Dias de Campos, além de } \\
\text { participar de diversos Projetos e Programas Governamentais de } \\
\text { Transferência de Tecnologia. Desde abril de 2016 é supervisor do Setor } \\
\text { de Implementação da Programação de Transferência de Tecnologia na } \\
\text { Embrapa Hortaliças e de fevereiro de 2017 e Chefe Adjunto Substituto } \\
\text { de Transferência de Tecnologia da Embrapa Hortaliças. }\end{array}$ \\
\hline \multirow{5}{*}{ ESP2 } & $\begin{array}{c}\text { Possui gradução em Engenharia Agronômica pela ESALQ (1989), } \\
\text { Doutorado em Fruticultura, comercialização e pós-colheita pela UNESP } \\
\text { (2014) e MBA Executivo na FGV em Economia e Gestão: Agronegócio } \\
\text { (2018). Atua como chefe da Seção do Centro de Qualidade } \\
\text { Hortigranjeira - SECQH na Companhia de Entrepostos e Armazéns } \\
\text { Gerais de São Paulo e Vice-Presidente da Sociedade Brasileira de } \\
\text { Fruticultura - SBF }\end{array}$ \\
\hline
\end{tabular}


Possui graduação em Engenharia Agronômica pela Universidade de São Paulo (1986), mestrado em Pós-Colheita pela University of Florida (1994), doutorado em Fitotecnia pela Universidade de São Paulo (1999) e pós-doutorado pela Texas A\&M University (2000). Pesquisador da ESP3 Embrapa Instrumentação. Professor credenciado no programa de pósgraduação em alimentos e nutrição da Faculdade de Ciências Farmacêuticas da UNESP, Campus Araraquara, SP e na Universidade Federal de São Carlos/UFSCAR. Coordenador do curso de tecnologia pós-colheita realizado na Embrapa Instrumentação desde 2011. Fonte: Autor adaptado de EMBRAPA (2020) e CEAGESP (2020)

Quadro 13 - Fornecedores

\begin{tabular}{|c|c|c|}
\hline NOME & Cargo & Empresa \\
\hline FOR1 & Sócio Freshveg & $\begin{array}{c}\text { Plataforma de compra e venda de } \\
\text { hortaliças online }\end{array}$ \\
\hline FOR2 & Gerente de Contas na Agrofresh & $\begin{array}{c}\text { Plataforma de compra e venda de } \\
\text { hortaliças online }\end{array}$ \\
\hline FOR3 & $\begin{array}{c}\text { Assessora no Sindicato Mogi Das } \\
\text { Cruzes }\end{array}$ & $\begin{array}{c}\text { Sindicato dos Trabalhadores Rurais } \\
\text { de Mogi das Cruzes }\end{array}$ \\
\hline FOR4 & Agrônomo na Plant Defender & $\begin{array}{c}\text { Fornecedora de tecnologia e } \\
\text { produtos para o plantio de hortaliças }\end{array}$ \\
\hline
\end{tabular}

Fonte: Autor

Nos quadros 11, 12 e 13, vemos a distribuição dos produtores de alface (7 entrevistados), batata (3 entrevistados), cebola (5 entrevistados), cenoura (3 entrevistados) e tomate (4 entrevistados), além dos fornecedores (4 entrevistados) e especialistas (3 entrevistados).

Os produtores foram divididos em dois grupos de acordo com o tamanho de faturamento, conforme o Quadro 14.

Quadro 14 - Tamanho em Faturamento dos Produtores

\begin{tabular}{|c|c|}
\hline Nome & Tamanho em Faturamento \\
\hline PRO1 & GRANDE PRODUTOR \\
\hline PRO2 & GRANDE PRODUTOR \\
\hline PRO3 & GRANDE PRODUTOR \\
\hline PRO4 & GRANDE PRODUTOR \\
\hline PRO5 & GRANDE PRODUTOR \\
\hline PRO6 & GRANDE PRODUTOR \\
\hline PRO7 & GRANDE PRODUTOR \\
\hline
\end{tabular}




\begin{tabular}{|c|c|}
\hline PRO8 & GRANDE PRODUTOR \\
\hline PRO9 & PEQUENO PRODUTOR \\
\hline PRO10 & PEQUENO PRODUTOR \\
\hline PRO11 & PEQUENO PRODUTOR \\
\hline PRO12 & PEQUENO PRODUTOR \\
\hline PRO13 & PEQUENO PRODUTOR \\
\hline PRO14 & PEQUENO PRODUTOR \\
\hline PRO15 & PEQUENO PRODUTOR \\
\hline
\end{tabular}

Fonte: Autor

Na Tabela 07 é possível verificar o perfil dos casos, cruzando escolaridade com os diferentes tipos de entrevistados.

Tabela 07 - Escolaridade

\begin{tabular}{|c|c|c|c|c|c|}
\cline { 3 - 6 } \multicolumn{2}{c|}{} & \multicolumn{5}{c|}{ Escolaridade } \\
\cline { 3 - 6 } \multicolumn{1}{c|}{} & $\begin{array}{c}\text { Ensino } \\
\text { Médio }\end{array}$ & $\begin{array}{c}\text { Ensino } \\
\text { Superior }\end{array}$ & $\begin{array}{c}\text { Não } \\
\text { Respondeu }\end{array}$ & \multirow{2}{*}{ TOTAL } \\
\hline \multirow{4}{*}{ Entrevistado } & Especialista & 0 & 3 & 0 & $\mathbf{3}$ \\
\cline { 2 - 6 } & Fornecedor & 0 & 3 & 1 & $\mathbf{4}$ \\
\cline { 2 - 6 } & $\begin{array}{c}\text { Grande } \\
\text { Produtor }\end{array}$ & 3 & 4 & 1 & $\mathbf{8}$ \\
\cline { 2 - 7 } & $\begin{array}{c}\text { Pequeno } \\
\text { Produtor }\end{array}$ & 4 & 1 & 2 & $\mathbf{7}$ \\
\cline { 2 - 7 } & TOTAL & $\mathbf{7}$ & $\mathbf{1 1}$ & $\mathbf{4}$ & $\mathbf{2 2}$ \\
\hline
\end{tabular}

Fonte: Autor

$\mathrm{Na}$ Tabela 07 entende-se que o pequeno produtor em sua totalidade tem escolaridade de nível médio, sendo a única exceção o produtor PRO13, que tem ensino superior e desempenha um papel social e educativo, em que fornece para um hospital universitário uma grande variedade de produtos e que funciona como uma "fazenda escola". Nesta mesma análise é possível verificar que os grandes produtores também não têm, em sua totalidade, o ensino superior, porém dada a distribuição entende-se que este é um fator para o crescimento do plantío e potencial uso da tecnologia. Os especialistas e fornecedores apresentam ensino superior. Dentre os produtores, especialistas e fornecedores, os que possuem escolaridade em nível superior cursaram os cursos de agronomia ou engenharia agronômica.

Referente ao uso de tecnologias de sensoriamento, na tabela 08 verificou-se uma concentração do uso nos grandes produtores. 
Tabela 08 - Utilização de Tecnologias de Sensoriamento

\begin{tabular}{|c|c|c|c|}
\hline & $\begin{array}{c}\text { Pequeno } \\
\text { Produtor }\end{array}$ & $\begin{array}{c}\text { Grande } \\
\text { Produtor }\end{array}$ & Total \\
\hline Não Utiliza Tecnologias de Sensoriamento & 7 & & 7 \\
\hline Utiliza Tecnologias de Sensoriamento & & 8 & 8 \\
\hline Total & 7 & 8 & 15 \\
\hline
\end{tabular}

Fonte: Autor

No que tange a idade, os produtores mais jovens não têm conseguido adotar tecnologias de sensoriamento, apresentando um peso maior no tamanho do plantio do que na idade e conhecimento tecnológico. Na tabela 09 verifica-se que os produtores que utilizam a tecnologia (grandes produtores) são em média mais velhos que os pequenos produtores.

Tabela 09 - Média de Idade dos Produtores

\begin{tabular}{|c|c|}
\hline & Média de Idade (anos) \\
\hline Não Utiliza Tecnologias de Sensoriamento & 36 \\
\hline Utiliza Tecnologias de Sensoriamento & 44 \\
\hline
\end{tabular}
Fonte: Autor

Os produtores entrevistados apresentam uma concentração na comercialização com entrepostos (10 entre os 15 entrevistados). Dos grandes produtores, apenas um não comercializa com grandes varejistas. A tabela 10 descrimina as quantidades por tipo de cliente.

Tabela 10 - Principais Clientes

\begin{tabular}{|c|c|}
\hline Clientes & Quantidade de Produtores \\
\hline Cooperativa & 1 \\
\hline Entrepostos & 6 \\
\hline Entrepostos e Grandes Varejistas & 4 \\
\hline Grandes Varejistas & 3 \\
\hline Hospitais & 1 \\
\hline
\end{tabular}

Fonte: Autor

Dado este perfil dos casos, na seção 5 verifica-se como os fatores do quadro teórico apresentado seção 3 impactam na adoção de Internet of Things no plantío de hortaliças. 


\section{RESULTADOS DA PESQUISA}

Esclarecido o que a pesquisa considera como Internet of Things e com o panorama obtido na seção 4.3, apresenta-se os resultados dos casos observados para detalhar os fatores que impulsionam ou barram a implementação de loT no plantio de hortaliças.

\subsection{RESULTADOS FATOR COMPORTAMENTAL}

No framework teórico de análise (Figura 11), o fator comportamental é uma composição dos construtos expectativa de performance, expectativa de esforço, influência social e condições facilitadoras. Tem como objetivo entender sob a perspectiva do usuário quais são os habilitadores ou limitadores do uso de tecnologia. Neste estudo, os usuários são os produtores e gestores da produção de hortaliças.

\subsubsection{Expectativade de Performance}

O primeiro construto, a expectativa de performance é impactada pelo vislumbramento de benefícios através da tecnologia. Perguntados se os produtores consideram que internet of things pode agregar qualidade e aumentar a produtividade no plantio de hortaliças, os especialistas ESP1 e ESP2 afirmaram que a maioria dos produtores tem o entendimento básico dos benefícios técnicos que loT pode trazer no dia a dia do plantio e não conseguem visualizar benefícios financeiros e de qualidade nos produtos. Os produtores PRO6 e PRO7 confirmam parte desta afirmação, em que um dos maiores motivadores é a maior facilidade de manuseio dos equipamentos e aplicação dos insumos, permitindo no caso de grandes propriedades, um controle fidedigno de toda a cultura. Estes mesmos produtores se diferenciam das afirmações dos especialistas principalmente em relação a irrigação, pois optaram pelo uso da tecnologia devido ao benefício do menor uso da água e consequente menor custo. De qualquer maneira, o incremento de qualidade no produto não foi um fator universal a todos produtores, sendo apontado apenas pelo produtor PRO4, em que seu diferencial é um tomate de alta qualidade para exportação e clientes que buscam produtos com alto padrão de qualidade e padronização.

Os fornecedores foram unanimes em relação a expectativa de performance, em que afirmam que os produtores, principalmente os pequenos, têm dificuldades em realizar a gestão financeira de seu negócio, dificultando a percepção dos possíveis 
benefícios em termos de redução de custos e insumos. Além destes pontos, afirmam que o principal motivador em relação a performance seria a redução de insumos na irrigação e fertilização do solo, confirmada pelos produtores PRO7 e PRO8 que já utilizam as tecnologias. No Quadro 15 seguem as afirmações destes produtores.

Quadro 15 - Irrigação e Fertilização do Solo

\begin{tabular}{|c|c|}
\hline \multicolumn{2}{|c|}{ Irrigação e Fertilização do Solo } \\
\hline PRO7 & $\begin{array}{c}{[\ldots] \text { utilizamos tecnologias de sensoriamento para controle da }} \\
\text { irrigação, medição da transpiração e iluminação. Para doenças ainda } \\
\text { está sendo desenvolvido. Utilizamos também para medir o } \\
\text { desempenho dos equipamentos [...] }\end{array}$ \\
\hline PRO8 & $\begin{array}{c}{[\ldots . .] \text { utilizamos a tecnologia da icrop, que fornece assessoria para }} \\
\text { controle climático e para irrigação. Auxílio também de imagem de } \\
\text { danos e doenças [...] }\end{array}$ \\
\hline
\end{tabular}

Fonte: Autor

Alguns dos produtores que já utilizam as tecnologias de sensoriamento afirmam que uma das barreiras referente a performance é a não adaptabilidade pelos fornecedores de tecnologia ao setor de hortaliças, muitas vezes trabalhando com produtos similares a grandes commodities como soja e milho, conforme comentado pelos PRO5 e PRO7. O problema da adaptabilidade, segundo o PRO1, se restringe a catalogação dos diferentes tipos de hortaliças, dos seus insumos, dos diferentes tipos de pragas e doenças e possíveis ajustes necessários para cada cultura. Como benefícios afirmam que a tecnologia garante maior controle e visibilidade de todo o processo do plantio, como por exemplo, o produtor $\mathrm{PRO} 3$ que reduziu o consumo de água no seu cultivo.

Os pequenos produtores, na totalidade dos casos estudados, não utilizam Internet of Things e confirmam novamente a afirmação dos especialistas (ESP1 e ESP2) de que veem benefícios relacionados ao manuseio, porém não utilizam loT pois a atual prática manual com uma equipe de irrigação, semeação e colheita é satisfatória para os seus respectivos fins de produção, conforme visto nos casos PRO9, PRO10 e PRO12. Estes produtores afirmam também que seus produtos, devido ao valor agregado baixo, não seriam comercializados com um preço mais elevado para que fosse viabilizada a adoção da tecnologia. Esta afirmação é confirmada, pois dos produtores de alface (produto de menor valor agregado dentre 
os estudados) apenas o produtor PRO2 é de grande porte e utiliza a tecnologia. O seu negócio funciona com grande volume de plantio, com vendas ao grande varejo e que viabilizam a adoção da tecnologia devido à escala. Este ainda afirma que só utiliza sensoriamento nas estufas, sendo o plantio de alface direto na terra muito volátil a mudanças climáticas devido ao ciclo de crescimento rápido (por volta de 40 dias). No Quadro 16 seguem os comentários dos produtores PRO9 e PRO12.

Quadro 16 - Expectativa de Performance dos Pequenos Produtores

\begin{tabular}{|c|c|}
\hline \multicolumn{2}{|c|}{ Expectativa de Performance dos Pequenos Produtores } \\
\hline PRO12 & $\begin{array}{c}{[\ldots] \text { não usaria as tecnologias de sensoriamento, pois já possuo os }} \\
\text { conhecimentos e ferramentas necessárias para o meu plantio [...] }\end{array}$ \\
\hline PRO9 & $\begin{array}{l}{[\ldots . .] \text { a tecnologia pode trazer benefícios no plantio, porém na prática }} \\
\text { não consigo visualizar ganhos financeiros com a implementação [...] }\end{array}$ \\
\hline
\end{tabular}

Fonte: Autor

Os produtores de batata, cenoura e cebola não se queixaram de problemas de escala, baixo valor agregado e técnicos na possível adoção de internet of things. Já o PRO1, produtor de tomate, comenta que há dificuldade de sensoriamento de doenças e pragas na implementação em mudas verticais, ainda necessitando de trabalhos manuais e de especialistas.

\subsubsection{Expectativa de Esforço}

Perguntados se a complexidade no uso dos equipamentos com tecnologia loT poderia ser uma barreira da sua utilização no plantío de hortaliças, percebeu-se que os pequenos produtores são os que mais sentem o impacto dessa complexidade. A complexidade apresenta-se como uma barreira importante para os pequenos produtores, aqueles que menos ouvem e estudam a tecnologia. Segundo o especialista ESP3, a escolaridade pode ser um fator decisivo para compreensão e utilização de loT. A afirmação é corroborada pois a maioria dos pequenos produtores não apresenta ensino superior. Ainda os especialistas ESP1 e ESP2 vão além, afirmam que o produtor não trocará a facilidade e seu manuseio atual, por processos mais complexos, com sensores, sistemas integrados e utilização de interfaces em tempo real. Um dos exemplos são os produtores PRO9 e PRO10, que afirmam manter 
processos manuais e sem sensoriamento, pois os compreendem e dominam mais que possíveis implementações tecnológicas. Este posicionamento é contestado pelos fornecedores FOR1 e FOR4, pois afirmam que a adoção da tecnologia pode ocorrer por meio de contratações, terceirizações ou estudos. No Quadro 17 segue o relato do PRO10, referente ao conhecimento da tecnologia e o seu atual manejo no plantio.

Quadro 17 - Conhecimento sobre IoT

\begin{tabular}{|c|c|}
\hline \multicolumn{2}{|c|}{ Conhecimento sobre loT } \\
\hline PRO10 & $\begin{array}{r}{[\ldots] \text { não saberia utilizar a tecnologia e, em nosso processo familiar, }} \\
\text { nós conseguimos produzir na quantidade e qualidade necessária } \\
\text { para fazermos as vendas nos entrepostos [...] }\end{array}$ \\
\hline
\end{tabular}

Fonte: Autor

Os produtores que utilizam tecnologias de sensoriamento afirmam contratar engenheiros agrônomos ou especialistas para garantir a aplicação da tecnologia, não sendo necessário o aprofundamento técnico, como nos casos dos produtores PRO1, PRO2, PRO3, PRO6, PRO7 e PRO8. O PRO1 e o PRO7 por exemplo comentam que uniram a necessidade domínio de tecnologias de sensoriamento com demandas de conhecimento biológico dos produtos cultivados, apoiados por startups.

No cenário dos pequenos produtores, essa possibilidade não é vislumbrada e acreditam que a saída para implementação seria pelo seu próprio conhecimento, que por sua vez é baixo e inviabiliza a adoção. Algumas adaptações foram encontratadas como o caso do PRO14 que utiliza pluviômetros de plástico para ajustar manualmente sua irrigação conforme a tendência de chuva. Mesmo com estas adaptações, estes agricultores estão distantes da eficiência e controle obtido com a adoção de Internet of Things.

\subsubsection{Influência Social}

Os produtores entrevistados em geral são proprietários ou gerentes das propriedades que atuam, desta maneira são influenciados por fatores externos a sua organização e não por agentes internos. Com este cenário, os questionamentos referentes a influência social tangenciaram a importância dada ao uso, recomendação e exigência por parte dos demais stakeholders. Os especialistas ESP1, ESP2 e ESP3 
e os fornecedores FOR1 e FOR3 afirmam que os produtores podem ser influenciados por orgãos reguladores, fornecedores e demais produtores que tenham contato com a tecnologia. Sob o ponto de vista dos pequenos agricultores, verifica-se que os produtores PRO9, PRO12 e PRO15 não são influenciados a utilizar tecnologias de sensoriamento. Os que afirmam ser influenciados (PRO10, PR011, PRO14), citam demais produtores que já utilizam e recomendam o uso, conforme o Quadro 18.

Quadro 18 - Influência Social nos pequenos produtores

\begin{tabular}{|c|c|}
\hline \multicolumn{2}{|c|}{ Influência Social nos pequenos produtores } \\
\hline PRO14 & $\begin{array}{c}{[\ldots . .] \text { conheço outros produtores que trabalham com plantio em }} \\
\text { estufas e facilitam o controle das folhosas através de sensoriamento } \\
{[. . .]}\end{array}$ \\
\hline PRO11 & $\begin{array}{c}{[\ldots] \text { sou influenciada pelos demais produtores devido ao esforço que }} \\
\text { é reduzido no manejo do plantio quando se tem alguma tecnologia } \\
\text { de sensoriamento [...] }\end{array}$ \\
\hline
\end{tabular}

Fonte: Autor

No cenário dos grandes produtores, alguns fatores de mercado atuam a favor da utilização da tecnologia, como por exemplo certificados internacionais e de qualidade. Estes são os casos dos produtores PRO1 e PRO8, em que afirmam que através da tecnologia podem exercer controles mais rígidos e processos melhor estruturados com intuito de obter tais certificações. Além disso, comentam que seus fornecedores, principalmente da indústria de biológicos, incentivam uma maior disseminação de tecnologias de sensoriamento no plantio. Dos fornecedores entrevistados, o FOR4 confirma este incentivo. Como ponto de influência negativa na adoção, o produtor PRO2 afirma que o cenário econômico pode barrar investimento e posteriores implementações. Segue Quadro 19 com os apontamentos referentes aos grandes produtores.

Quadro 19 - Influência Social nos grandes produtores

\begin{tabular}{|c|c|}
\hline \multicolumn{2}{|c|}{ Influência Social nos grandes produtores } \\
\hline PRO1 & $\begin{array}{r}{[\ldots] \text { um de nossos concorrentes se certificou na ISO 9001, e as }} \\
\text { tecnologias que envovem internet of things auxiliam no processo de } \\
\text { controle e automatização, viabilizando a certificação [...] }\end{array}$ \\
\hline FOR4 & $\begin{array}{r}{[\ldots . .] \text { para os grandes produtores a influência vem do mercado, }} \\
\text { através da concorrência, em que incentivamos a tecnologia como } \\
\text { caminho para uma melhor rentabilidade no processo do plantio [...] }\end{array}$ \\
\hline
\end{tabular}


[...] devido ao aumento nos custos de produção referentes ao aumento do dolar, do petróleo, da energia elétrica e do salário dos colaboradores, nós grandes produtores não estamos investindo em tecnologia no campo com este cenário externo [...]

Fonte: Autor

Por fim, o especialista ESP3 afirma que a vida pessoal do produtor pode influenciar na adoção de internet of things, uma vez que o contato cotidiano com aplicativos de mensagem, de serviço bancário e demais interfaces tecnológicas podem familiarizar o agricultor e facilitar o seu acesso a tecnologia.

\subsubsection{Condições Facilitadoras}

Referente as condições facilitadoras ao uso de internet of things, os entrevistados avaliaram se a estrutura do plantio relacionado a mão de obra, terreno, equipamentos e internet são aderentes à adoção de tecnologias de sensoriamento. Os especialistas da EMBRAPA (ESP1 e ESP3) comentam que produtores mais afastados de grandes centros urbanos, podem ter maior dificuldade com sinal de internet e acesso à pessoas especializadas no uso. Ao mesmo tempo que afirmam isso, pontuam que as hortaliças geralmente são produzidas próximas à grandes metrópoles, devido à perecibilidade de alguns de produtos, como por exemplo as folhosas no cinturão verde de São Paulo.

Dos produtores entrevistados, todos pontuaram que o sinal de internet é suficiente para suas necessidades, afirmando que este fator não é um impeditivo ao uso internet of things. Os produtores $\mathrm{PRO} 2$ e PRO7, que já utilizam loT, pontuaram que é possível realizar o monitoramento offline, através de uma rede interna ou com descargas periódicas de dados. $\mathrm{O}$ produtor $\mathrm{PRO} 2$ citou o uso de tablets para monitoramentos pontuais e descargas de dados em um servidor central, conforme verifica-se no Quadro 20. 
Quadro 20 - Monitoramento Offline

\begin{tabular}{|c|c|}
\hline \multicolumn{2}{|c|}{ Monitoramento Offline } \\
\hline PRO7 & $\begin{array}{c}{[\ldots] \text { trabalhamos em uma rede offline, com compartilhamento das }} \\
\text { informações das estações metereológicas da região e } \\
\text { semanalmente a empresa especializada atualiza as informações } \\
\text { em rede [...] }\end{array}$ \\
\hline PRO2 & $\begin{array}{c}{[\ldots] \text { as empresas parceiras e especialistas fazem a aplicação da }} \\
\text { tecnologia, porém é necessário o entendimento por parte dos } \\
\text { funcionários para uso de tablets e aplicações dos insumos, } \\
\text { enquanto realizamos alguns procedimentos offline [...] }\end{array}$ \\
\hline
\end{tabular}

Fonte: Autor

Os grandes produtores, nos casos PRO7 e PRO8, se beneficiam da estrutura de outros produtos, como soja e milho, para adotar loT na produção de hortaliças. Em alguns casos, dependendo da região é possível compartilhar estações metereológicas, satélities e sensores, como por exemplo na região de São Gotardo em Minas Gerais, nos casos dos produtores PRO5, PRO6, PRO7 e PRO8. Enquanto isso, para os pequenos produtores um dos maiores impeditivos é a questão dos recursos humanos somado a falta de equipamentos para o uso básico de internet of things, como por exemplo a falta de computadores, problema citado tanto pelos produtores (PRO9, PRO10, PRO 14 e PRO15) quanto pelos especialistas (ESP3).

Por fim, para os produtores de tomate, verifica-se que a produção na modalidade vertical enfrenta problemas de adaptação de tecnologia para monitoramento de doenças e pragas, pois a maior parte do direcionamento tecnológico é voltado para o solo e plantas rasteiras. No geral, estes produtores utilizam loT para o acompanhamento da germinação e da nutrição do produto cultivado. O fornecedor FOR1 afirma que o uso de tecnologias de sensoriamento deveria ser voltado ao solo e aos nutrientes, o que não se concretiza com as necessidades dos produtores de tomates que necessitam do monitoramento vertical, explicitado pelo posicionamento do produtor PRO1.

\subsection{RESULTADOS FATOR TECNOLÓGICO}

O fator tecnológico é uma composição dos construtos custo e disponibilidade para implementação de internet of things, conforme visto na seção 3.1 . 


\subsubsection{Custo}

O custo foi o fator mais citado pelos entrevistados, sendo uma das principais barreiras à utilização de internet of things e que segrega pequenos e grandes produtores no momento da adoção. Para todos os especialistas (ESP1, ESP2 e ESP3), os grandes produtores não veem problemas com os custos de implementação da tecnologia. Já os pequenos necessitam de maiores incentivos e recursos para especializar seu plantio. Além disso, citam que regiões mais remotas e afastadas dos grandes centros podem apresentar maiores custos, devido a logística, implementação de interfaces remotas e deslocamento de especialistas.

Outro fator que diferencia os grandes e pequenos produtores é visão sobre o gasto com a tecnologia. Para os grandes produtores a implementação é vista como investimento a ser diluido no longo prazo, que trará benefícios e até lucro, a depender das economias obtidas com o uso. Os produtores PRO1, PRO3, PRO6 e PRO7, por exemplo, citam reduções de custo na irrigação. Os pequenos agricultores, como por exemplo o PRO9, PRO10, PRO11, PRO12, PRO13, PRO14 e PRO15, citam que não há necessidade deste custo, dado que o seu processo atual atende suas necessidades. Outro ponto que tangencia todos os pequenos agricultores é a falta de informação, em que a maioria não conhecia ou nunca pesquisou sobre a tecnologia, e acreditam que o custo de implementação é elevado. A gestão do custo e benefício obtido tangencia a expectativa de performance e o conhecimento sobre a tecnologia, distanciando os pequenos e grandes produtores.

Por fim, o fornecedor FOR1 afirma que internet of things pode reduzir custos em toda a cadeia de suprimentos, interligando o plantio com os demais elos e assim viabilizando ganhos para os produtores e o consumidor final. Agricultores de produtos de menor valor comercial, que possuem menor margem de lucro e tem menor flexibilidade organizacional para investimentos, poderiam se beneficiar desta interligação de agentes da cadeia. Já os agricultores de produtos com maior valor comercial têm maior possibilidade de investimento e por usa vez tem menos dificuldades com os custos da adoção de loT. 


\subsubsection{Disponibilidade}

O acesso à tecnologia pode variar conforme a localização do produtor, afirma o especialista ESP3, da EMBRAPA. No geral, os pequenos produtores não pesquisam e não sabem onde encontrar dispositivos ou parceiros que viabilizem a adoação. $O$ fornecedor FOR3, assessora do sindicato de Mogi das Cruzes, afirma que cooperativas e sindicatos podem ter papel importante na orientação destes produtores e auxiliá-los a encontrar e compartilhar os equipamentos a fim de baratear o uso. $\mathrm{O}$ cenário de estações compartilhadas auxiliou alguns dos grandes produtores entrevistados neste estudo (PRO5, PRO6, PRO7 e PRO8), em que o compartilhamento de estações e uso de tecnologias integradas viabilizou o uso em suas propriedades. A empresa detentora e manuseadora da tecnologia, Icrop, implementou na região de São Gotardo estações metereológicas e equipamentos de sensoriamento que permitiram aos produtores maior assertividade no uso da água e consequente menor custo, tanto pela economia, quanto pelo compartilhamento das informações.

No cenário dos agricultores que já utilizam a tecnologia, alguns impeditivos foram encontrados, como a inexistência ou defasagem nas informações relacionadas as especificidades das hortaliças. Como exemplo, o PRO1 cita que o receituário dos diferentes tipos de tomates e diferentes tipos de insumos não é atualizado e aplicado em tempo real, sendo necessária a análise de um especialista. Referente às pragas e doenças, só encontrou serviços de pragueiros de forma remota através de aplicativos de mensagem, sem uma interação em rede online e estruturada. O PRO2 comenta também que para a produção de alfaces em terra é afetada pela inconstancia de iluminação oriunda das variações do tempo, inibindo neste produto de ciclo rápido, a adoção de loT. No Quadro 21 segue evidência dos pontos levantados pelos produtores. 
Quadro 21 - Evidências sobre Disponibilidade

\begin{tabular}{|c|c|}
\hline \multicolumn{1}{|c|}{ Disponibilidade de Tecnologia } \\
\hline PRO1 & $\begin{array}{c}\text { [...] a tecnologia está acessível para temas de irrigação e } \\
\text { adubação, porém ainda de maneira muito vaga para } \\
\text { implementações de controle de informação no plantio de } \\
\text { hortaliças. Por exemplo, o receituário dos diferentes tipos de } \\
\text { tomates e diferentes tipos de insumos não é atualizado e } \\
\text { aplicado em tempo real, sendo necessária a análise de um } \\
\text { especialista. Referente a pragas e doenças, só encontro } \\
\text { serviços de pragueiros de forma remota através do whatsapp, } \\
\text { sem uma interação em rede mais automática e bem preparada } \\
\text { [...] }\end{array}$ \\
\hline PRO 2 & $\begin{array}{c}\text { [...] as tecnologias existentes não atendem as demandas da } \\
\text { geografia e clima do Brasil, sendo por isso que uma boa parte } \\
\text { da produção em terra é manual. O terreno acidentado e a } \\
\text { inconstância de iluminação não permitem o uso de máquinas de } \\
\text { plantio automático e previsibilidade no cultivo [...] }\end{array}$ \\
\hline
\end{tabular}

Fonte: Autor

Outro ponto comentado pelo PRO5 é a disponibilidade de interconexão com outras culturas que já utilizam loT e que migram para as hortaliças o conhecimento e aplicação. Por fim o FOR4 e o PRO8, afirmam que fornecedores de nutrientes e sementes, também viabilizam a digitalização do plantio através de auxílio consultivo e tecnológico.

\subsection{RESULTADOS FATOR ORGANIZACIONAL}

O fator organizacional é uma composição do tamanho e estrutura da empresa, conforme visto na seção 3.1. Dos produtores entrevistados, verificou-se a presença de diferentes tipos de organizações, desde as mais simples com poucos agricultores até grandes corporações. Os produtores PRO9, PRO10, PRO11 e PRO12 afirmaram compor a organização apenas com membros da família e poucas pessoas externas, dividindo lucros e compartilhando decisões. Já o PRO13, PRO14 e PRO15, apesar do pequeno porte e pequena estrutura, desenvolviam suas atividades com um formato vertical de tomada de decisão, sendo centralizado no proprietário da terra. Os produtores $\mathrm{PRO} 1, \mathrm{PRO} 2, \mathrm{PRO} 3, \mathrm{PRO}$, $\mathrm{PRO5}, \mathrm{PRO6}, \mathrm{PRO} 7$ e PRO8 são grandes organizações, com diferentes departamentos como setores financeiro, produtivo e de distribuição. 
A variação de estrutura entre os pequenos e grandes produtores influencia diretamente na adoção de Internet of Things, como por exemplo a modalidade de produtores com agricultura familiar. Este tipo de estrutura, segundo o produtor PRO10 e o especialista ESP3, dificulta a adoção de tecnologias, dado que, para a tomada de decisão, uma quantidade elevada de pessoas deverá opinar, tornando este processo inflexível e demorado.

Outro fator que tangencia os pequenos produtores é a cultura de diferentes gerações que mantém as mesmas práticas de cultivo e restringe o processo de adoção. Segundo o especialista ESP2, os agricultores são resistentes à mudança e se não vislumbrarem ganhos diretos com a implementação da tecnologia, dificilmente alterarão seus processos internos. Já o PRO1, associa que além da resistência à mudança, a baixa escolaridade dos pequenos agricultores dificulta a ascenção organizacional e, consequente, melhoria do plantio. Como soluções a este processo, o FOR3 afirma que é importante o apoio de cooperativas e dos grandes varejistas, uma vez que não haverá proatividade para a adoção.

Referente aos grandes produtores, o maior controle e gerenciamento organizacional permite que os benefícios de internet of things sejam percebidos, que estes agricultores consigam seguir as tendências de mercado e se atualizem conforme as normas vigentes. Um dos principais fatores para adoção destes produtores é a exigência dos grandes varejistas para questões de qualidade e controle no plantio, incentivando investimentos em troca de grandes vendas. Este processo não acontece para os pequenos produtores. No Quadro 22, seguem alguns pontos comentados pelo ESP1 e PRO1.

Quadro 22 - Evidências Estrutura Organizacional

\begin{tabular}{|c|c|}
\hline \multicolumn{2}{|c|}{ Estrutura Organizacional } \\
\hline & $\begin{array}{c}\text { [...] grandes produtores e cooperativas que atendem ao grande } \\
\text { varejo tem a exigência em utilizar algumas tecnologias para garantir } \\
\text { os padrões de qualidade e a rastreabilidade das condições dos } \\
\text { produtos. Neste cenário a tecnologia é uma ferramenta para garantir } \\
\text { as boas práticas dos produtores e atender as exigências dos } \\
\text { consumidores finais da cadeia de suprimentos [...] }\end{array}$ \\
\hline
\end{tabular}


[...] grandes produtores estão mais preocupados com as questões da qualidade do produto, padronização e acesso a novos mercados, sendo que isso impulsiona a procura e o uso de tecnologia, incluindo IoT $[\ldots]$

Fonte: Autor

Para os agricultores que produzem uma grande variedade de produtos, foram apresentados dois casos. O caso do produtor PRO13, pequeno produtor, verifica-se que a grande variedade de produtos produzidos em pequena escala dificulta a adoção de internet of things, uma vez que o processo de adaptação a cada especificidade será mais complexo. Já o PRO3, grande produtor, mesmo com a grande variedade de produtos, conseguiu para poucas culturas adaptar a tecnologia, sendo influenciado pelas culturas que já tinha implementado anteriormente. Conclui-se que a variedade pode expandir o uso de tecnologias de sensoriamento para produtos que ainda não estavam abrangidos, porém este processo necessita de escala e investimento, que na maioria dos casos está concentrado nos grandes produtores. No Quadro 23 seguem diferentes abordagens referente ao tamanho dos produtores.

Quadro 23 - Diferença entre pequenos e grande produtores

\begin{tabular}{|c|c|}
\hline \multicolumn{2}{|c|}{ Diferença entre pequenos e grandes produtores } \\
\hline PRO5 & $\begin{array}{c}{[\ldots] \text { alguns produtores são influênciados pelos demais produtores, }} \\
\text { principalmente de outros produtos como Soja e Milho que migram } \\
\text { algumas tecnologias para o plantio de batata [...] }\end{array}$ \\
\hline ESP2 & $\begin{array}{c}{[\ldots] \text { diferença muito grande entre pequenos e grandes produtores, }} \\
\text { sendo os maiores mais iterados das recomendações, normas e } \\
\text { tendências. Os pequenos produtores são mais dependentes do } \\
\text { atravessador [...] }\end{array}$ \\
\hline ESP3 & $\begin{array}{c}{[\ldots] \text { os grandes produtores têm mais acesso a informação e poder de }} \\
\text { investimento, causando um distanciamento tecnológico em relação } \\
\text { ao menor produtor [...] }\end{array}$ \\
\hline
\end{tabular}

Fonte: Autor

Por fim, no caso do produtor PRO4, em que detém todos os elos para plantio, distribuição e comercialização de tomates, verifica-se que esta verticalização da cadeia de suprimentos pode facilitar o investimento em sensoriamento, uma vez que o controle dos processos se torna mais decisivo no negócio. Fatores indiretos, como causas trabalhistas foram citados pelos grandes produtores, em que o gerenciamento 
e automatização do plantio otimiza o quadro de funcionários ou melhora as condições dos colaboradores do campo.

\subsection{RESULTADOS FATOR AMBIENTAL}

O fator ambiental é uma composição dos construtos pressão competitiva e apoio do governo e regulamentações para implementação de internet of things, conforme visto na seção 3.1 .

\subsubsection{Pressão Competitiva}

Referente à pressão competitiva e fatores de mercado, alguns agentes atuam exclusivamente no segmento das hortaliças, como por exemplo, os atravessadores. Segundo os especialistas ESP1 e ESP2, os atravessadores são compradores fixos dos produtores (geralmente pequenos) que garantem a comercialização dos produtos em troca de baixos preços. Esta modalidade de negociação acomoda os produtores devido ao baixo risco, incentivado pelos atravessadores que, na cadeia de valor, acabam com a maior parte do lucro. Essa parceria beneficia apenas os atravessadores, prejudicando os produtores que ficam com margens de lucro menores e os consumidores que não recebem produtos com maior qualidade e rastreabilidade. No Quadro 24 seguem comentários dos especialistas.

Quadro 24 - Atravessadores

\begin{tabular}{|c|c|}
\hline \multicolumn{2}{|c|}{ Atravessadores } \\
\hline ESP1 & $\begin{array}{c}{[\ldots] \text { muitos produtores se apoiam na venda com baixa margem de }} \\
\text { lucro para os atravessadores para que não tenham riscos de buscar } \\
\text { novos clientes e desta maneira investem menos em tecnologia e na } \\
\text { qualidade do plantio }\end{array}$ \\
\hline ESP2 & {$[\ldots]$ os pequenos produtores são mais dependentes do atravessador } \\
{$[\ldots]$}
\end{tabular}

Fonte: Autor

Nas relações de mercado dos grandes produtores, verifica-se que a manutenção e conquista de contratos de venda com grandes varejistas se dá com requisitos de qualificação da produção, padronização, rastreabilidade e maior controle dos processos. Esta exigência incentiva os produtores a investir em tecnologia, que 
se torna viável pela escala e pelos preços acordados. Alguns casos como os produtores PRO2, PRO3 e PRO4 foram verificados no Quadro 25.

Quadro 25 - Grandes Varejistas

\begin{tabular}{|c|c|}
\hline \multicolumn{2}{|r|}{ Grandes Varejistas } \\
\hline PRO2 & $\begin{array}{l}\text { [...] grandes compradores e seus clientes exigem do produtor maior } \\
\text { foco na qualidade, o que desencadeia na busca por tecnologia [...] }\end{array}$ \\
\hline PRO3 & {$[\ldots]$ fui impulsionado pelo varejo $[\ldots]$} \\
\hline PRO4 & $\begin{array}{c}{[\ldots] \text { aderência aos padrões exigidos aos grandes players do }} \\
\text { mercado varejista }[. . .]\end{array}$ \\
\hline ESP3 & $\begin{array}{c}{[\ldots] \text { produtores buscam a tecnologia para acessar mercados maiores }} \\
\text { e mais exigentes }[. . .]\end{array}$ \\
\hline
\end{tabular}

Fonte: Autor

No caso PRO2, em um cenário que poucos produtores de alface se especializaram nas questões de controle do plantio, este produtor se destacou e recebeu o incentivo de grandes varejistas para implementar tecnologias que viabilizassem um produto mais confiável e padronizado. Já o PRO4 iniciou seu trabalho com tomates na comercialização e ao longo dos anos adentrou no plantio com intuito de conquistar novos compradores de grande porte, sendo estes os clientes que viabilizaram seu negócio.

A exigência pela rastreabilidade, segundo todos especialistas (ESP1, ESP2 e ESP3), é uma demanda dos consumidores, em que é necessário conhecer a procedência dos produtos e as práticas adotadas para sua composição. Segundo o ESP2, esta demanda é paralela ao aumento da produção e comercialização de produtos orgânicos, pressionando os agricultores a dosar, controlar e escolher melhor seus agentes biológicos no plantio, processo este viabilizado por Internet of Things.

Dos entrevistados que afirmam utilizar tecnologias de sensoriamento, os questionamentos referentes à pressão competitiva divergem opiniões. Os produtores PRO6 e PRO8 comentam que a adoção é influenciada majotariamente pela melhoria interna e técnica, enquanto os produtores PRO1, PRO2, PRO3, PRO4 e PRO7 afirmam que seus clientes, certificações, mercado externo, fornecedores e a exigência por rastreabilidade foram fatores decisivos, conforme o Quadro 26. 
Quadro 26 - Pressão Competitiva

\begin{tabular}{|c|l|}
\hline \multicolumn{2}{|c|}{ Pressão Competitiva } \\
\hline PRO1 & $\begin{array}{l}\text { [...] sentimos uma pressão competitiva voltada para boas práticas no } \\
\text { plantio e melhoria da qualidade do produto, visto que um de nossos } \\
\text { concorrentes é certificado na ISO 9001. Não almejamos a } \\
\text { certificação no curto prazo, mas sim investir na melhoria do plantio e } \\
\text { na adequação as regulamentações. Os consumidores são mais } \\
\text { exigentes em relação a qualidade e a rastreabilidade do produto [...] }\end{array}$ \\
\hline PRO2 & $\begin{array}{l}\text { [...] estratégia do nosso grupo foi investir em maior qualidade na } \\
\text { produção, com produtos mais biológicos, se preocupando em } \\
\text { atender as demandas de qualidade e sabor da folhosas, isso } \\
\text { através de tecnologia e motivada pela pressão em diferenciar } \\
\text { nossos produtos exercida pelos compradores [...] }\end{array}$ \\
\hline PRO6 & $\begin{array}{l}{[\ldots] \text { não fomos influenciados pelo mercado, mas sim buscamos uma }} \\
\text { melhoria interna no manejo dos produtos, não só no plantio e } \\
\text { colheita, mas também na separação e distribuição [...] }\end{array}$ \\
\hline
\end{tabular}

Fonte: Autor

\subsubsection{Apoio do Governo e Regulamentações}

Os especialistas foram unânimes em afirmar que a lei de rastreabilidade é um dos maiores incentivos regulatórios ao uso de Internet of Things, uma vez que demanda do produtor o controle de datas do cultivo, uso de fertilizantes, dados sobre o manejo do plantio e da colheita. Com essas exigências, os produtores necessitam maior organização e processos controlados, o que é permitido pelo sensoriamento e dosagem oriundos da loT. A interligação com os demais sistemas e a etiquetagem dos produtos aumentam o fluxo de informação da cadeia de valor, o que é melhor gerenciado por dispositivos interconectados. Os demais sistemas inseridos nesta conexão podem ser interfaces de fornecedores, compradores, operadores de transporte e do consumidor final.

O fornecedor FOR3 e o especialista ESP3 comentam que a rastreabilidade forçou os produtores a sair da zona de conforto e conhecer novas oportunidades. $O$ exemplo disso é o produtor PRO10 que conheceu as empresas e aplicativos que auxiliam o rastreio dos produtos após a exigência em lei. 
No Quadro 27, encontram-se algumas opiniões de produtores e especialistas sobre a lei de rastreabilidade.

Quadro 27 - Rastreabilidade

\begin{tabular}{|c|c|}
\hline \multicolumn{2}{|c|}{ Lei de Rastreabilidade } \\
\hline ESP2 & $\begin{array}{c}{[\ldots] \text { a lei de rastreabilidade tem sido o grande motor para promover e }} \\
\text { incentivar o uso de tecnologia no plantio de hortaliças [...] }\end{array}$ \\
\hline ESP3 & $\begin{array}{c}\text { [...] a lei de rastreabilidade pode ter retirado os produtores da zona } \\
\text { do conforto para começar a discutir o uso de aplicativos, maiores } \\
\text { controles no campo e uso de tecnologia de informação [...] }\end{array}$ \\
\hline
\end{tabular}

Fonte: Autor

Os produtores de pequeno porte foram mais impactados pela lei, dado que trabalham com processos e controles mais simples. No caso PRO9, verifica-se que durante a maior fiscalização da lei, este produtor iniciou o processo de marcação das embalagens das folhosas e posteriormente a pandemia do COVID-19 regrediu-se a exigência e consequentemente o uso de etiquetas e aplicativos para controle do plantio e colheita. O especialista ESP3 é contrário a este afrouxamento da regulamentação no período da pandemia, dado que este é o cenário que mais se exigem controles sanitários, o que seria intensificado pela lei de rastreabilidade. Segue comentário do produtor PRO9 no Quadro 28.

Quadro 28 - Pandemia coronavírus e a lei de rastreabilidade

\begin{tabular}{|c|c|}
\hline \multicolumn{2}{|c|}{ Pandemia coronavírus e a lei de rastreabilidade } \\
\hline PRO9 & $\begin{array}{l}\text { [...] a pandemia do coronavírus reduziu a exigência de } \\
\text { rastreabilidade por parte dos orgãos reguladores [...] }\end{array}$ \\
\hline
\end{tabular}

Fonte: Autor

Os grandes produtores, como por exemplo PRO8, PRO3 e PRO4 se adequaram à rastreabilidade mesmo antes de sua exigência, impactando menos na aderência a lei e a tecnologias para controle. Estes produtores afirmam que o movimento de rastreabilidade é benéfico ao uso de tecnologia, uma vez que profissionaliza o setor e aumenta a confiabilidade dos produtos numa escala geral. No Quadro 29, seguem comentários sobre a lei de rastreabilidade. 
Quadro 29 - Grandes Produtores e a Lei de Rastreabilidade

\begin{tabular}{|c|c|}
\hline \multicolumn{2}{|c|}{ Grandes Produtores e a Lei de Rastreabilidade } \\
\hline PRO8 & $\begin{array}{c}{[\ldots] \text { a lei de rastreabilidade ajuda a profissionalizar o mercado e }} \\
\text { indiretamente incentiva o uso da tecnologia para controle [...] }\end{array}$ \\
\hline PRO3 & $\begin{array}{c}{[\ldots] \text { lei de rastreabilidade não nos influênciou na tomada de decisão }} \\
\text { de utilizar a tecnologia, pois já aderiamos aos requisitos antes da } \\
\text { exigência [...] }\end{array}$ \\
\hline PRO4 & $\begin{array}{c}{[\ldots] \text { já seguia os protocolos da rastreabilidade antes da existência da }} \\
\text { lei [...] }\end{array}$ \\
\hline
\end{tabular}

Fonte: Autor

Referente ao apoio do governo, os produtores relatam a falta de incentivos, linhas de crédito e suporte para a rastreabilidade sem um suporte prévio. Alguns relatos seguem no Quadro 30.

Quadro 30 - Apoio Governamental

\begin{tabular}{|c|c|}
\hline ESP1 & $\begin{array}{c}\text { Apoio Governamental } \\
{[\ldots] \text { no Brasil o governo exigiu a rastreabilidade para parte das }} \\
\text { hortaliças e não deu o suporte necessário para implementação das } \\
\text { tecnologias, delegando esta função aos estados [...] }\end{array}$ \\
\hline PRO10 & $\begin{array}{c}{[\ldots] \text { há incentivo para utilização do caderno do campo, através de }} \\
\text { empresas como IDHA e PariPassu [...] }\end{array}$ \\
\hline PRO9 & $\begin{array}{c}{[\ldots] \text { o governo não auxilia o produtor no processo de adoção da lei }} \\
\text { de rastreabilidade e tem exigido implementações que geram } \\
\text { prejuízo de tempo e custo ao negócio [...] }\end{array}$ \\
\hline PRO2 & {$[\ldots]$ baixo apoio do governo a incentivo a tecnologia [...] } \\
\hline FOR1 & {$[\ldots]$ faltam incentivos fiscais [...] } \\
\hline
\end{tabular}

Fonte: Autor

Outros fatores indiretos foram apontados pelo PRO1, em que afirma que licenças ambientais e a manutenção do solo tem melhor gestão após o uso de Internet of Things. As licenças ambientais seriam obtidas com maior facilidade por conta da delimitação da propriedade, controle do uso dos agentes biológicos e a gravação destas informações ao longo do tempo. Já a manutenção do solo é impactada positivamente por Internet of Things quando o sensoriamento permite verificar qual o momento da troca da adubação e do local de plantio. Os apontamentos do PRO1 seguem no Quadro 31. 
Quadro 31 - Fatores indiretos

\begin{tabular}{|c|c|}
\hline \multicolumn{2}{|c|}{ Fatores Indiretos } \\
\hline PRO1 & $\begin{array}{c}{[\ldots] \text { somos impulsionados pela lei de rastreabilidade e pela lei de }} \\
\text { licença ambiental referente ao solo e as propriedade de cultivo }[\ldots]\end{array}$ \\
\hline
\end{tabular}

Fonte: Autor

Após os apontamentos dos produtores, especialistas e fornecedores em torno dos fatores de adoção, na seção 6 , verifica-se a discussão em torno da teoria e dos resultados obtidos. 


\section{DISCUSSÃO DOS RESULTADOS}

Para discussão dos resultados, elaborou-se quadros resumos, em que há o comparativo dos principais apontamentos levantados pelos produtores, especialistas e fornecedores, em relação ao que foi proposto no quadro teórico da seção 3 .

\subsection{DISCUSSÃO FATOR COMPORTAMENTAL}

O primeiro construto analisado no fator comportamental, a expectativa de performance, tem como objetivo avaliar se o indivíduo acredita que através tecnologia obterá ganhos de qualidade, produtividade e controle no processo do plantio, junto a uma vantagem relativa comentada nos estudos de Gutierrez, Boukrami e Lumsden (2015) e Sun et Al. (2016). No Quadro 32 seguem principais apontamentos em relação a este construto.

Quadro 32 - Principais apontamentos - Expectativa de Performance

\begin{tabular}{|c|c|c|}
\hline Fatores & Produtores de Grande Porte & Produtores de Pequeno Porte \\
\hline $\begin{array}{l}\text { Expectativa } \\
\text { de } \\
\text { Perfomance }\end{array}$ & $\begin{array}{ll}\text { - } & \text { Redução de custo de irrigação } \\
& \text { (PRO1,PRO2,PRO6 e PRO7) } \\
\text { - } & \text { Redução do uso de insumos } \\
& \text { (PRO1, PRO7 e PRO8) } \\
\text { - } & \text { Facilidade no manuseio de } \\
& \text { equipamentos (PRO1, PRO2 } \\
& \text { e PRO6), } \\
\text { - } & \text { Incremento de qualidade no } \\
& \text { produto (PRO2 e PRO6) } \\
\text { - } & \text { Controle de grandes } \\
\text { propriedades (PRO1 e PRO6) }\end{array}$ & $\begin{array}{l}\text { - Dificuldade na percepção dos } \\
\text { benefícios, devido ao baixo } \\
\text { controle e conhecimento } \\
\text { (FOR1,FOR2,FOR3,FOR4,ESP3) } \\
\text { - Os processos de plantio atual } \\
\text { atendem suas exigências de } \\
\text { produção (PRO9, PRO10 e } \\
\text { PRO12) }\end{array}$ \\
\hline
\end{tabular}

Fonte: Autor

Com este cenário, verifica-se que os grandes produtores foram impactados positivamente pela expectativa de performance, dado que com a conjuntura de gestão e poder de investimento conseguiram e conseguem avaliar os ganhos com o uso dos aparatos tecnológicos. Os ganhos obtidos tangenciaram três principais pontos:

- Redução de custo com água e insumos;

- Maior controle e gestão da produção, propriedade e equipamentos;

- Incremento de qualidade no produto. 
Em contrapartida, os pequenos produtores apresentaram resistência em relação a tecnologia, principalmente no comparativo com os processos que praticam nas suas propriedades de maneira tradicional e hereditária. Alguns produtores afirmam não vislumbrar ganhos com o uso da tecnologia e por isso não investiriam em loT. As principais barreiras foram:

- Manutenção das práticas atuais

- Baixa gestão do negócio e seus indicadores;

Desta maneira, o construto "expectativa de performance" impacta diretamente na adoção de internet of things, pois a distinção entre os produtores que adotaram ou não adotaram passou pelo crivo da avaliação dos benefícios no longo prazo e do rompimento das atuais práticas de plantio. Um fator indireto que corrobora com este cenário, é a menor escolaridade dos pequenos produtores, uma vez que com menor conhecimento, se perpetuam as práticas e tecnologias utilizadas. Fortalecem esta afirmação, os estudos de Alhogail (2018) e Gutierrez, Boukrami e Lumsden (2015), que também verificaram respectivamente que Internet of Things e Computação em Núvem são impactados pela percepção da vantagem relativa.

O segundo construto observado no fator comportamental é a "expectativa de esforço", suportada pelo grau de complexidade que o usuário atrela a tecnologia. No Quadro 33 são apresentados os principais resultados.

Quadro 33 - Principais apontamentos - Expectativa de Esforço

\begin{tabular}{|c|c|c|}
\hline Fatores & Produtores de Grande Porte & Produtores de Pequeno Porte \\
\hline $\begin{array}{l}\text { Expectativa } \text { de } \\
\text { Esforço }\end{array}$ & $\begin{array}{l}\text { - A adoção da tecnologia pode } \\
\text { ocorrer por meio de } \\
\text { contratações e terceirizações } \\
\text { (FOR1, FOR4, PRO1, PRO2, } \\
\text { PRO3, PRO6, PRO7 e } \\
\text { PRO8) } \\
\text { - ou por meio da contratação } \\
\text { de engenheiros agrônomos } \\
\text { ou especialistas (PRO4) } \\
\text { - ou através do apoio de } \\
\text { fornecedores de insumos } \\
\text { (PRO1 e PRO7) }\end{array}$ & $\begin{array}{l}\text { - O grau de escolaridade } \\
\text { impacta no entendimento } \\
\text { das tecnologias e do } \\
\text { negócio (ESP3) } \\
\text { - Tendem em não trocar os } \\
\text { seus processos atuais para } \\
\text { novos processos com maior } \\
\text { complexidade (ESP1, } \\
\text { ESP2, PRO9, PRO10) } \\
\text { Creditam o uso da } \\
\text { tecnologia apenas pelos } \\
\text { próprios conhecimentos, } \\
\text { sem a ajuda de } \\
\text { especialistas (PRO11, } \\
\text { PRO12 e PRO15) }\end{array}$ \\
\hline
\end{tabular}

Fonte: Autor 
Os entrevistados compartilharam a forma que lidaram com a questão técnica da tecnologia e como solucionaram ou não a questão da complexidade. Primeiramente, os grandes produtores afirmaram que não tiveram problemas na implementação, dado que investiram em pessoas especializadas (terceiros ou contratados) para manutenção da tecnologia. Esta estratégia foi abordada por todos estes produtores, dado que por questões estratégicas, se mantém especialistas no mercado das hortaliças e trazem especialistas em tecnologia para atuar nas demandas de Internet of Things. Na conjuntura de mercado, estes produtores têm maior facilidade de encontrar parceiros, pois possuem maior poder de investimento, escala e contato com os fornecedores de tecnologia.

No cenário dos pequenos agricultores de hortaliças, verifica-se que a terceirização e auxílio de especialistas não é discutido por nenhum dos produtores, principalmente por serem impactados na questão do custo. O principal fator é o não acesso aos detentores da tecnologia, que desencadeia na busca individual pela implementação tecnológica. Com esta busca individual, o pequeno produtor se vê incapacitado em operar os dispositivos e desiste de uma possível adoção de Internet of Things.

Verifica-se que a expectativa de esforço pode ser uma barreira na adoção de internet of things, principalmente se a questão da complexidade não é avaliada com as condições de contorno junto a especialistas e empresas parceiras. Os produtores se mantêm especialistas no plantio, independentemente do porte, porém a gestão da adoção de loT é diferenciada através do acesso aos detentores do conhecimento tecnológico.

O terceiro construto referente ao fator comportamental é a "influência social", que vislumbra verificar como os agentes que são referencia aos produtores impactam na sua decisão pela adoção ou não de Internet of Things. Alguns estudos similares como o de Alhogail (2018), comentam que o interesse da comunidade influencia positivamente a confiança na adoção de loT, conforme apontado pelo ESP3 na afirmação de que os produtores são influenciados pelos costumes na vida pessoal, como por exemplo na utilização de aplicativos e dispositivos de remotos. Nos estudos de Masood e Egger (2019), encontram-se que os usuários associam negativamente o uso da tecnologia. Nesta mesma linha de posicionamento, os entrevistados, afirmam 
que pequenos produtores não optam pelo uso da tecnologia pois preferem manter seus processos atuais. No Quadro 34, seguem os principais pontos referente a influência social.

Quadro 34 - Principais apontamentos - Influência Social

\begin{tabular}{|c|c|c|}
\hline Fatores & Produtores de Grande Porte & Produtores de Pequeno Porte \\
\hline Influência Social & 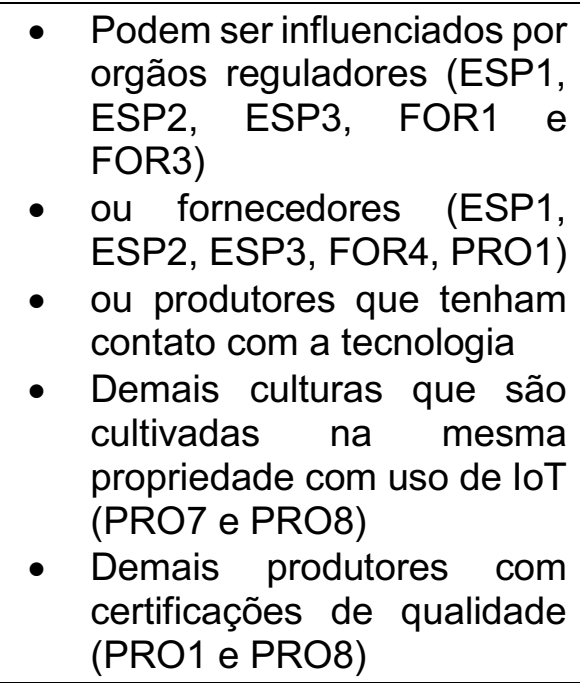 & $\begin{array}{llr}\text { - } & \text { São influenciados por } \\
\text { demais produtores } & \text { pro11 e } \\
\text { (PRO10, PRO11 } & \\
\text { PRO14) } & \\
\text { - } & \text { Influenciados r pelos } \\
\text { costumes na vida pessoal } & \\
\text { (ESP3) } & \\
\text { ou não se sentem } \\
\text { influenciados (PRO9, } \\
\text { PRO12 e PRO15) }\end{array}$ \\
\hline
\end{tabular}

Fonte: Autor

Os grandes produtores, por apresentarem uma rede de contatos mais ampla, com fornecedores e clientes maiores, são mais influenciados socialmente para o uso da tecnologia. São estes também que estão atentos às tendências de mercado e buscam adequar sua produção ao que gera maior eficiência no processo do plantio e da colheita.

Os pequenos produtores, tem visões distintas em relação a Internet of Things, com nenhuma influência por parte de qualquer stakeholder ou apresentando indicações de outros produtores que implementaram em suas propriedades. Esta influência no cenário micro, cria uma visão básica dos benefícios, porém não afeta diretamente o seu negócio, fazendo com que não chegue a ser um fator que auxilia positivamente na adoção de tecnologias de sensoriamento.

A influencia social, por fim, impacta apenas os grandes produtores, pois são estes que o cenário macro oferta as tecnologias de sensoriamento e ao mesmo tempo, os produtores estão atentos a tendências de mercado. Para os pequenos produtores a influência é muito pequena e não desencadeia na adoção, dado que os exemplos muitas vezes não são concretos e adaptáveis. 
No último construto do fator comportamental, verifica-se como o produtor avalia suas condições profissionais, processuais e de infraestrutura para adotar internet of things. As "condições facilitadoras" foram resumidas no Quadro 35.

Quadro 35 - Principais apontamentos - Condições Facilitadoras

\begin{tabular}{|c|c|c|}
\hline Fatores & Produtores de Grande Porte & Produtores de Pequeno Porte \\
\hline $\begin{array}{l}\text { Condições } \\
\text { Facilitadoras }\end{array}$ & 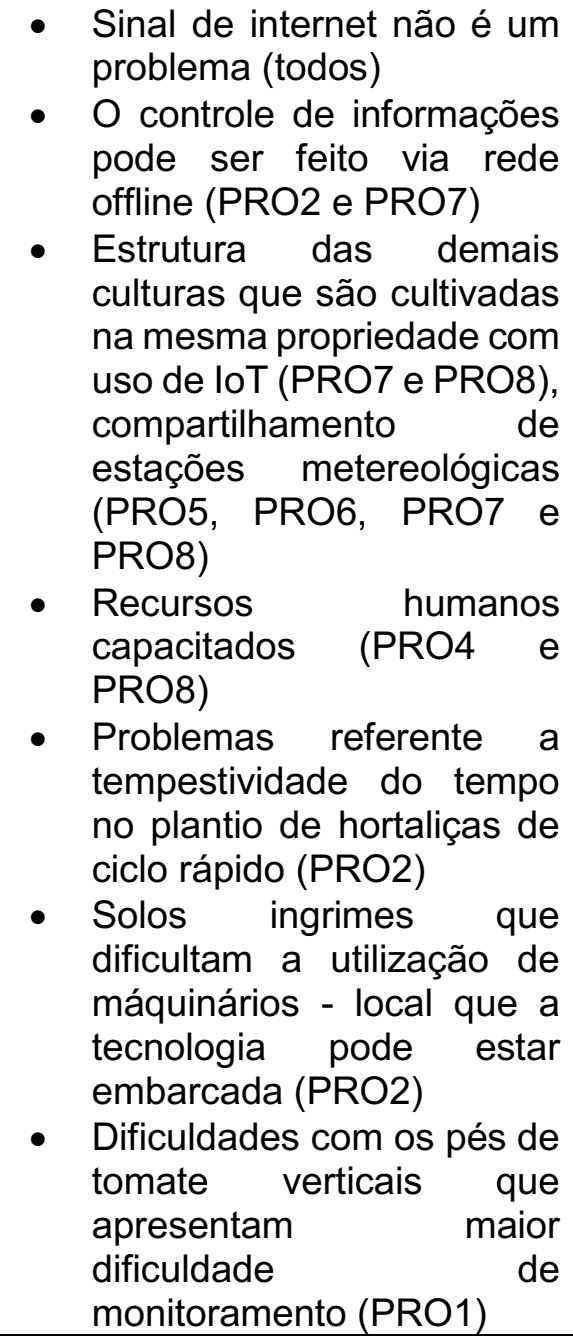 & $\begin{array}{l}\text { - } \begin{array}{l}\text { Sinal de internet não é um } \\
\text { problema } \\
\text { produtores) }\end{array} \\
\text { - Falta de computadores } \\
\text { (PRO9, PRO10, PRO14, } \\
\text { PRO15 e ESP3) } \\
\text { - Falta de recursos humanos } \\
\text { capacitados (PRO9, } \\
\text { PRO10, PRO14, PRO15 e } \\
\text { ESP3) }\end{array}$ \\
\hline
\end{tabular}

Fonte: Autor

Um dos pontos citados pelos especialistas ESP1 e ESP3 fora o problema de acesso a internet em regiões mais remotadas. O produtor PRO8 afirmou que em alguns locais de sua propriedade o sinal de rede oscila, porém não é um impeditivo para utilização da tecnologia. Neste mesmo cenário, todos os produtores entrevistados, independente do porte ou região sinalizaram que utilizam internet para fins pessoais ou profissionais. 
A internet, quando abordada pelos produtores, verifica-se que não é um fator determinante no momento do controle do plantio, dado que as informações podem ocorrer em redes internas. O PRO1 e PRO7 apontaram que o uso da internet é importante para gestão do negócio longe das propriedades, porém no dia a dia o controle pode ser realizado sem a conexão externa.

Alguns produtores, como o PRO1 e o PRO2, percebem problemas nas condições de plantio de seus produtos. Por exemplo, os tomates de tipo vertical, apresentam dificuldades no monitoramento de doenças e pragas. Já as folhosas, mais voláteis ao tempo e ao curto ciclo de plantio, não conseguem quando produzidas na terra embarcar tecnologias. Outro ponto importante apontado pelo PRO2 é em relação a formação dos terrenos nas regiões produtivas brasileiras, em que se observa solos ingrímes que dificultam a utilização de máquinas agrícolas.

Os produtores de menor porte, afirmam que a ausência de computadores e pessoas quem entendam da tecnologia dificultam a adoção de internet of things. Conclui-se que as "condições facilitadoras" não impactam diretamente a adoção de internet of things, dado que são viáveis situações de contorno para solos íngrimes, falta de internet e monitoramento de doenças e pragas para situações específicas. Estes pontos ficam como sugestões de melhoria para a Internet of things, porém não inviabilizam a adoção.

No Quadro 36, verifica-se a composição final do fator comportamental.

Quadro 36 - Resultados - Fator Comportamental

\begin{tabular}{|c|c|c|}
\hline Grande Produtor & $\begin{array}{c}\text { Impacto na } \\
\text { Adoção }\end{array}$ & Como? \\
\hline $\begin{array}{c}\text { Expectativa de } \\
\text { Perfomance }\end{array}$ & SIM & $\begin{array}{r}\text { Expectativa de ganhos de qualidade, controle e } \\
\text { redução de insumos }\end{array}$ \\
\hline $\begin{array}{c}\text { Expectativa de } \\
\text { Esforço }\end{array}$ & SIM & $\begin{array}{r}\text { Se mantém especialistas no plantio e contratam } \\
\text { especialistas na tecnologia }\end{array}$ \\
\hline Influência Social & SIM & $\begin{array}{r}\text { Influênciados pelos demais stakeholders } \\
\text { interessados e demais produtores }\end{array}$ \\
\hline $\begin{array}{c}\text { Condições } \\
\text { Facilitadoras }\end{array}$ & NÃO & $\begin{array}{r}\text { As condições facilitadoras não habilitam e não } \\
\text { atrapalham a adoção de loT }\end{array}$ \\
\hline $\begin{array}{c}\text { Pequeno } \\
\text { Produtor }\end{array}$ & $\begin{array}{c}\text { Impacto na } \\
\text { Adoção }\end{array}$ & Como? \\
\hline $\begin{array}{c}\text { Expectativa de } \\
\text { Perfomance }\end{array}$ & SIM & $\begin{array}{c}\text { Não tem controles para verificar possíveis } \\
\text { ganhos e preferem as práticas tradicionais }\end{array}$ \\
\hline
\end{tabular}




\begin{tabular}{|c|c|c|}
$\begin{array}{c}\text { Expectativa de } \\
\text { Esforço }\end{array}$ & SIM & $\begin{array}{c}\text { Resistentes a alteração nos processos do } \\
\text { plantio por novos processos com loT e não } \\
\text { vislumbram terceirizações }\end{array}$ \\
\hline $\begin{array}{c}\text { Influência Social } \\
\text { Condições } \\
\text { Facilitadoras }\end{array}$ & NÃO & $\begin{array}{c}\text { Influência social pequena através de casos } \\
\text { relatados por demais produtores }\end{array}$ \\
\hline $\begin{array}{c}\text { As condições facilitadoras não habilitam e não } \\
\text { atrapalham a adoção de loT }\end{array}$ \\
\hline
\end{tabular}

Fonte: Autor

Os indivíduos que avaliam a adoção de internet of things tem um papel importante na avaliação do seu cenário interno, com seus processos e controles, e do cenário externos através da influência de outros agentes do segmento das hortaliças. A expectativa de performance por exemplo varia conforme o produtor consegue avaliar suas condições internas, seu conhecimento e como a adoção pode the trazer benefícios no longo prazo. A percepção deste produtor é o fator chave, pois existem condições de contorno demonstradas pelos atuais usuários de tecnologia. A resistência ainda é um fator importante e que é melhor administrada quando o produtor apresenta uma estrutura que viabiliza o entendimento do negócio.

No sentido de entender as questões da tecnologia, do negócio e do ambiente externo, verifica-se nas próximas seções a análise dos fatores organizacionais provenientes do TOE.

\subsection{DISCUSSSÃO FATOR TECNOLÓGICO}

O primeiro construto analisado no fator tecnológico, o custo, tem como objetivo avaliar se os possíveis gastos dispendidos com a implementação de internet of things podem ser uma barreira aos produtores, conforme verificado em Sun et Al. (2016), em que as possíveis despesas com Big Data podem impactar na adoção da tecnologia. No Quadro 37 seguem principais apontamentos em relação a este construto. 
Quadro 37 - Principais apontamentos - Custo

\begin{tabular}{|c|c|c|}
\hline Fatores & Produtores de Grande Porte & Produtores de Pequeno Porte \\
\hline Custo & 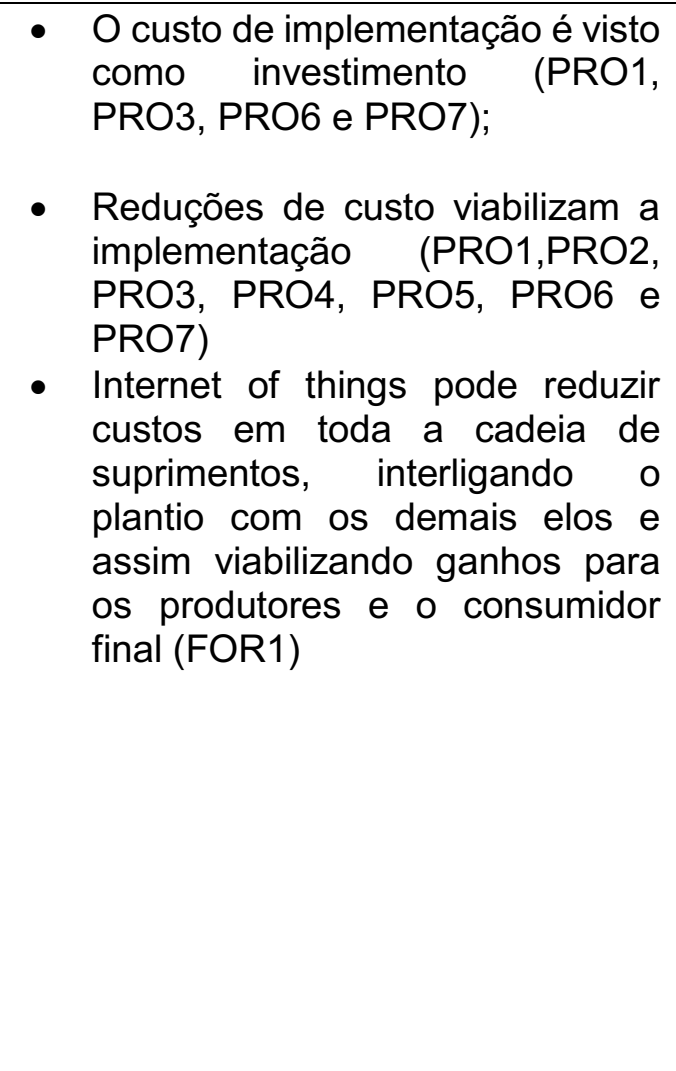 & $\begin{array}{l}\text { - } \text { Falta de informação sobre os } \\
\text { custos (PRO9, PRO10, PRO11, } \\
\text { PRO12, PRO13, PRO14 e } \\
\text { PRO15) } \\
\text { - Regiões mais remotas e } \\
\text { afastadas dos grandes centros } \\
\text { podem apresentar maiores } \\
\text { custos, devido a logística, } \\
\text { implementação de interfaces } \\
\text { remotas e deslocamento de } \\
\text { especialistas (ESP1, ESP2 e } \\
\text { ESP3) } \\
\text { Pequenos produtores acreditam } \\
\text { que a tecnologia aumentará o seu } \\
\text { custo de produção (PRO9, } \\
\text { PRO10, PRO11, PRO12, } \\
\text { PRO13, PRO14 e PRO15) } \\
\text { - Falta de gestão do negócio para } \\
\text { avaliar o possível retorno do } \\
\text { investimento tecnológico (FOR3) } \\
\text { Produtos com menor valor } \\
\text { comercial tem menor margem } \\
\text { para investimentos (FOR3 e } \\
\text { PRO9) }\end{array}$ \\
\hline
\end{tabular}

Fonte: Autor

Com este cenário, os grandes produtores afirmaram que o custo da implementação é um fator a ser considerado, porém dado o plano de redução de custos e benefícios no manuseio, o investimento compensa os gastos. Esta visão custo-benefício, verificada também na expectativa de performance, só é permitida quando o produtor realiza controles na gestão do seu negócio. Na ótica dos pequenos produtores, o custo é um impeditivo apontado como a maior barreira para implementação, mesmo que a maioria não tenha pesquisado cotações ou informações para adoção. Este ponto é confirmado quando se comparam as margens de lucro destes pequenos produtores, em que não há espaço para investimentos. Linhas de crédito foram citadas com inexistentes ou com juros altos, inviabilizando na maioria dos casos a evolução organizacional destas pequenas propriedades.

Entende-se que o custo de implementação de Internet of Things impacta nas decisões dos produtores no momento da adoção da tecnologia, principalmente se não houver um plano de diluição dos gastos no longo prazo em conjunto do ganho de performance obtido na evolução dos controles do plantio. 
O segundo construto analisado no fator tecnológico, a disponibilidade, tem como objetivo avaliar se a composição atual das tecnologias disponíveis atende a demanda dos produtores de hortaliças, conforme verificado nos estudos de Gutierrez, Boukrami e Lumsden (2015) e Masood e Egger (2019), referente a importância da prontidão tecnológica. No Quadro 38 seguem os principais apontamentos em relação a este construto.

Quadro 38 - Principais apontamentos - Disponibilidade

\begin{tabular}{|c|c|c|}
\hline Fatores & Produtores de Grande Porte & Produtores de Pequeno Porte \\
\hline Disponibilidade & 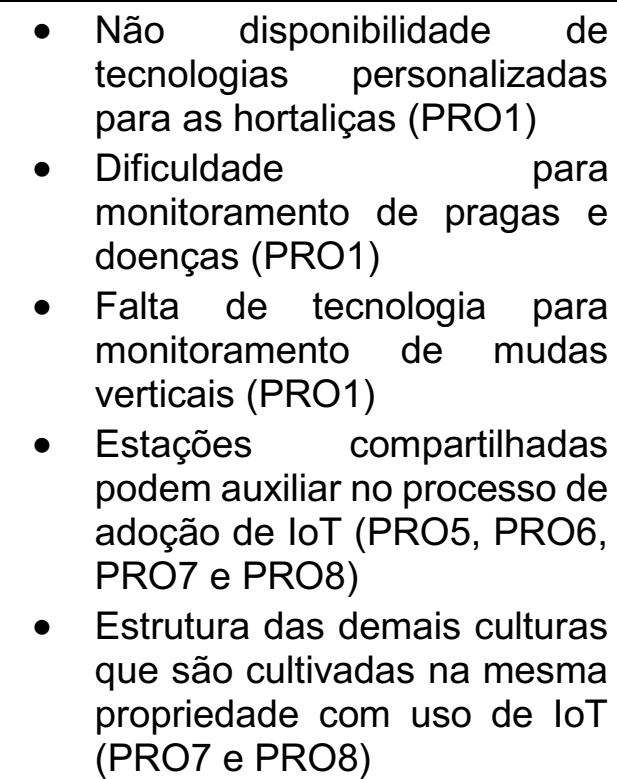 & $\begin{array}{l}\text { - Cooperativas e sindicatos } \\
\text { podem auxiliar os pequenos } \\
\text { produtores a encontrar as } \\
\text { tecnologias de Internet of } \\
\text { Things (FOR3) } \\
\text { - Pequenos produtores nunca } \\
\text { procuraram ou não sabem } \\
\text { onde encontrar a tecnologia } \\
\text { (PRO9, PRO10, PRO11, } \\
\text { PRO12, PRO14, PRO15) }\end{array}$ \\
\hline
\end{tabular}

Fonte: Autor

Os produtores que adotaram internet of things, citam que a tecnologia ainda não consegue abranger todas as exigências do plantio de hortaliças, pois falta adaptabilidade aos diferentes tipos de produtos. Os detentores das tecnologias apresentam uma padronização de sensoriamento voltada para grandes commodities (como soja e milho), que são aproveitadas nas hortaliças, porém não atendem os diferentes tipos de catalogação de insumos, pesticidas, doenças e variações das hortaliças. Esta defasagem de informação não é um impeditivo tecnológico, dado que a maior parte do sensoriamento ocorre no solo, porém inviabiliza a utilização completa e integrada de internet of things.

Avalia-se que as tecnologias estão disponíveis e que os pequenos produtores têm maiores dificuldades de sair da zona de conforto para procurá-las. Parte deste cenário se dá por conta da influência social, conforme visto no fator comportamental, 
em que não há incentivos para utilização de tecnologia. Os apoiadores deste segmento de produtores, como sindicatos e cooperativas podem ter papel importante para viabilizar a disponibilização da tecnologia e torná-la viável econômicamente.

No Quadro 39, encontra-se a composição final do fator tecnológico.

Quadro 39 - Resultados - Fator Tecnológico

\begin{tabular}{|c|c|c|}
\hline Grande Produtor & $\begin{array}{l}\text { Impacto na } \\
\text { Adoção }\end{array}$ & Como? \\
\hline Custo & SIM & $\begin{array}{l}\text { Realizam um plano de investimento e é um } \\
\text { critério avaliado antes da adoção de loT }\end{array}$ \\
\hline Disponibilidade & NÃO & $\begin{array}{l}\text { A tecnologia é encontrada com facilidade e } \\
\text { mesmo com problemas de adaptabilidade, } \\
\text { não impede a adoção de internet of things }\end{array}$ \\
\hline Pequeno Produtor & $\begin{array}{l}\text { Impacto na } \\
\text { Adoção }\end{array}$ & Como? \\
\hline Custo & SIM & $\begin{array}{l}\text { O custo é apontado como critério limitante a } \\
\text { adoção de internet of things, porém é pouco } \\
\text { avaliado pelos pequenos produtores }\end{array}$ \\
\hline Disponibilidade & NÃO & $\begin{array}{l}\text { Há disponibilidade de tecnologia, porém não } \\
\text { há procura por parte dos produtores }\end{array}$ \\
\hline
\end{tabular}

Fonte: Autor

No que tange o fator tecnológico, a disponibilidade atende a demanda das organizações que decidiram pela adoção, apenas com apontamentos referente a adaptabilidade, sem impactar na decisão final. Já o custo é a questão avaliativa para tomada de decisão por parte dos grandes produtores e um fator limitador, mesmo que sem pesquisa prévia, para os pequenos produtores, que com menores margens de lucro apresentam maiores dificuldades para investimento.

\subsection{DISCUSSÃO FATOR ORGANIZACIONAL}

O fator organizacional foi avaliado conforme um único construto, o tamanho e estrutura da empresa. Objetivo deste fator consiste em verificar que as variações nas composições das organizações podem definir a decisão sobre a adoção de internet of things. Estudos similares, como o de Gutierrez, Boukrami e Lumsden (2015) em Big Data e Masood e Egger (2019) em Realidade Aumentada, apontam que tamanho e estrutura das empresas estão positivamente associadas ao uso das tecnologias. Em Internet of Things, verifica-se o mesmo direcionamento, com organizações maiores e 
mais estruturadas conseguindo avaliar e adotar tecnologias. No Quadro 40 observamse as principais afirmações dos entrevistados.

Quadro 40 - Principais apontamentos - Tamanho e Estrutura da Empresa

\begin{tabular}{|c|c|c|}
\hline Fatores & Produtores de Grande Porte & Produtores de Pequeno Porte \\
\hline $\begin{array}{l}\text { Tamanho e Estrutura } \\
\text { da Empresa }\end{array}$ & $\begin{array}{l}\text { - } \text { Maior controle } \\
\text { gerenciamento } \\
\text { organizacional permite que } \\
\text { os benefícios de internet of } \\
\text { things sejam percebidos } \\
\text { (FOR3 e ESP1) } \\
\text { - Produtores croiores } \\
\text { possuem clientes com } \\
\text { maior poder de compra, } \\
\text { que incentivam o uso de } \\
\text { tecnologia (ESP3, PRO1, } \\
\text { PRO2 e PRO4) } \\
\text { Grande variedade de } \\
\text { produtos no plantio pode } \\
\text { dificultar a adoção uma vez } \\
\text { que cada produto } \\
\text { apresenta sua } \\
\text { especificidade, a menos } \\
\text { que ocorra uma priorização } \\
\text { (PRO3 e PRO13) } \\
\text { Produtores verticais que } \\
\text { detém a produção, } \\
\text { separação, transporte e } \\
\text { comercialização } \\
\text { apresentam maior pode de } \\
\text { investimento para adoção } \\
\text { de loT (PRO4) }\end{array}$ & 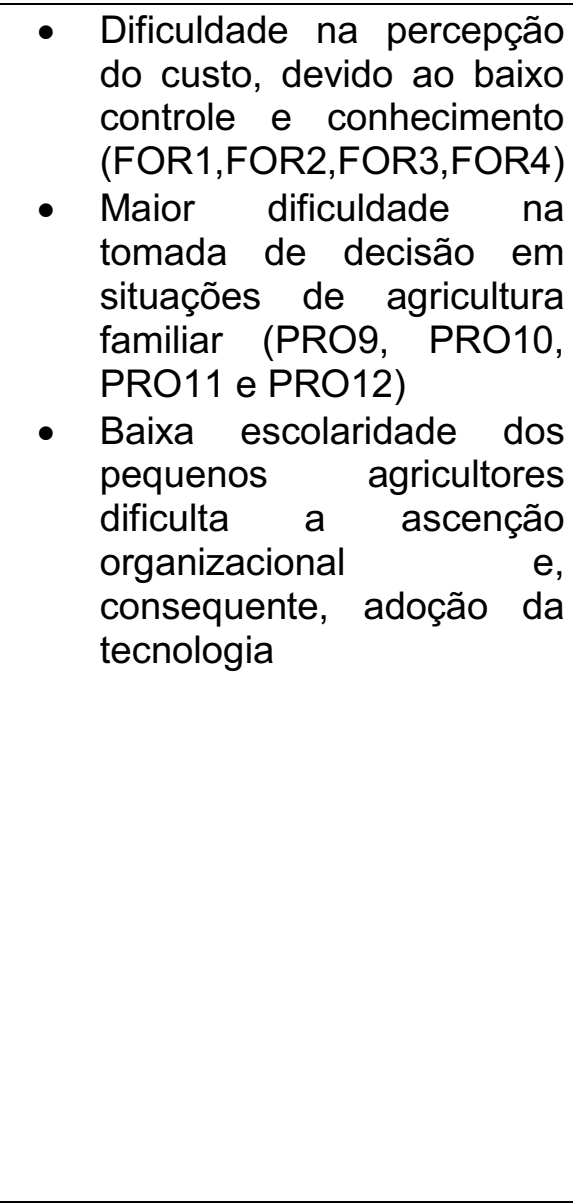 \\
\hline
\end{tabular}

Fonte: Autor

O posicionamento entre diferentes portes de produtores é verificado nos demais fatores, em que se observa o pequeno produtor mais dependente, acomodado e sem poder de investimento, enquanto o grande produtor consegue avaliar seus ganhos e riscos. A questão cultural e a influência social também impactam em diferentes medidas os diferentes tamanhos de produtores.

A gestão do negócio é realizada de forma continua e organizada nos grandes produtores, em que se observa recursos humanos especializados nas questões financeiras, do plantio e da tecnologia. Nos pequenos, esta falta de gestão impacta diretamente na percepção dos possíveis benefícios de tecnologia. A diferença na especialização ocorre também por conta dos diferentes graus de escolaridade dos 
líderes de cada organização, em que, produtores maiores, mesmo que sem escolaridade em nível superior, conseguem contar com profissionais com esta qualificação e que auxiliam o seu negócio. Os pequenos na sua totalidade apresentaram escolaridade de nível médio.

A agricultura familiar se apresentou como barreira no processo de adoção, pois os produtores e especialistas apontam que há uma maior participação de diferentes pessoas no processo decisório, dificultando a aceitação por todos envolvidos. Verificase também que produtores neste tipo de estrutura, apresentam menor custo com recursos humanos e tendem a não investir em pessoas externas, principalmente sem o contato manual com o plantio (situação dos especialistas em tecnologia).

Referente as estruturas dos grandes produtores, observa-se que produtores que detém mais elos da cadeia de abastecimento das hortaliças veem maior valor no uso de tecnologias de sensoriamento, dado que o fluxo de informação entre o plantio, separação, distribuição e vendas é um fator decisivo no negócio. Outro ponto verificado é que produtores com diversidade de produtos podem transferir tecnologias entre diferentes culturas, desde que ocorra uma priorização. Em um dos casos dos pequenos produtores, a diversificação dos produtos é grande e isso é um impeditivo para adoção de internet of things, uma vez que cada produto apresenta um parâmetro e especificidade.

No Quadro 41 encontra-se a composição final do fator organizacional.

Quadro 41 - Resultados - Fator Organizacional

\begin{tabular}{|c|c|c|}
\hline Produtores & $\begin{array}{c}\text { Impacto na } \\
\text { Adoção }\end{array}$ & Como? \\
\hline $\begin{array}{c}\text { Tamanho e Estrutura da } \\
\text { Empresa }\end{array}$ & SIM & $\begin{array}{c}\text { Produtores mais estruturados, maiores e com maior } \\
\text { poder de investimento tem maior propensão em } \\
\text { adotar internet of things. Pequenos produtores } \\
\text { podem ser impactos pela falta de gestão ou } \\
\text { estruturas familiares. }\end{array}$ \\
\hline
\end{tabular}

Fonte: Autor

O fator organizacional se funde aos demais fatores, pois as diferentes composições organizacionais direcionam como produtor lidará com o processo de adoção de internet of things. Este fator impacta diretamente na intenção de uso, nos 
relacionamentos, no mercado e no entendimento da tecnologia. Além disso, na amostra dos 15 produtores entrevistados, os produtores de grande porte em sua totalidade adotaram loT e os de pequeno porte, não adotaram, mostrando uma segregação dos diferentes tipos de empresas e confirmando a relevância do fator.

\subsection{DISCUSSÃO FATOR AMBIENTAL}

O primeiro construto analisado no fator ambiental, a pressão competitiva tem como objetivo avaliar se os parceiros comerciais, fornecedores e clientes impactam os produtores no momento da adoção de Internet of Things. Encontra-se no estudo de Gutierrez, Boukrami e Lumsden (2015) a afirmação de que a pressão competitiva influencia na adoção de computação em núvem. Em relação a Internet of Things não é diferente, impactando diretamente nas práticas adotadas pelos produtores. No Quadro 42 segue resumo dos apontamentos em relação a este construto.

Quadro 42 - Principais apontamentos - Pressão Competitiva

\begin{tabular}{|c|c|c|}
\hline Fatores & Produtores de Grande Porte & Produtores de Pequeno Porte \\
\hline Pressão Competitiva & 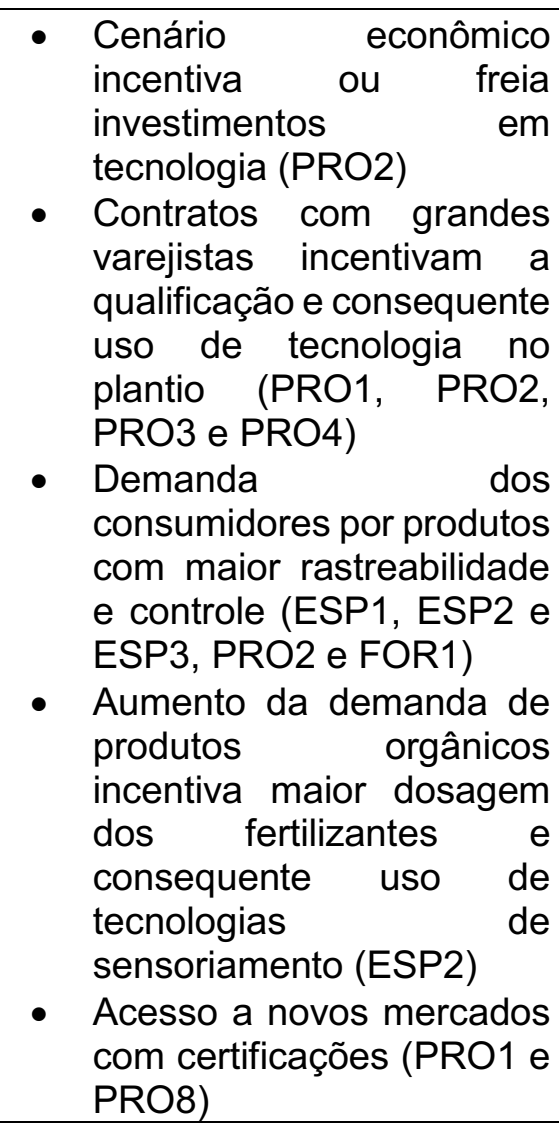 & $\begin{array}{l}\text { - Atravessadores acomodam } \\
\text { os pequenos produtores } \\
\text { em relação a busca de } \\
\text { melhoria no plantio (ESP1 } \\
\text { e ESP2) }\end{array}$ \\
\hline
\end{tabular}




\begin{tabular}{|l|l|l|}
\hline & $\begin{array}{l}\text { Acesso ao mercado } \\
\text { externo (PRO8) }\end{array}$ \\
$\bullet$ & $\begin{array}{l}\text { Incentivo dos fornecedores } \\
\text { (ESP1, ESP2, } \\
\text { ESP3,FOR4, PRO1) }\end{array}$ \\
\hline
\end{tabular}

Fonte: Autor

A pressão competitiva, como visto na "influência social", impacta o produtor na sua capacidade de realizar a comercialização do seu produto, de acordo com as exigências dos seus clientes e mercado, forçando o produtor a sair da zona de conforto. Os pequenos produtores apresentaram menor pressão competitiva, devido ao formato de venda garantida para os atravessadores. Esta estratégia de vendas, diminuem as margens de lucros, porém garantem a comercialização sem grandes exigências de qualidade. Para o setor de hortaliças, muitos dos pequenos agricultores se apoiam neste sistema de vendas, devido a perecibilidade dos produtos e a baixa capacitação para procurar novos mercados e clientes. Esta estabilidade inibe a busca de melhorias no plantio e consequentemente a adoção de loT.

Os grandes produtores, devido ao contato com maiores varejistas, exportações e mercados seletos, seguem a busca por tendências de qualidade, padronização e tecnologia, influenciando o uso de tecnologias, principalmente as de sensoriamento, como loT. Referente aos varejistas, a exigência por rastreabilidade dos produtos por parte dos consumidores finais, faz com que os produtores iniciem controles mais rigídos através de loT para informar as dosagens de insumos, datas de plantio e colheita, além do controle do pós-colheita, garantindo assim produtos com maior confiabilidade.

O acesso a estes mercados e clientes, somado a influência dos fornecedores de insumos, são fatores que influenciam diretamente na decisão pelo uso de internet of things e que diferenciam pequenos e grandes produtores. $O$ cenário econômico pode impulsionar ou freiar a tendência de uso de tecnologia, devido a incerteza para realizar investimentos, porém não é um fator decisivo na adoção de loT.

O último construto analisado no fator ambiental e no modelo teórico, "Apoio do Governo e Regulamentações", tem como objetivo avaliar se o suporte governamental é um habilitador ao uso de tecnologia e se a legislação vigente impacta na decisão sobre o uso de loT. No estudo de Sun et al. (2016), no contexto de big data, a 
influência governamental e seu suporte agiliza o processo de adoção, uma vez que a tecnologia facilita o controle e a segurança das informações. No contexto de internet of things no Brasil, verifica-se baixo suporte do governo, sem incentivos em linhas de crédito, subsídio ou apoio informacional. No Quadro 43, encontra-se resumo das principais observações deste construto.

Quadro 43 - Principais apontamentos - Apoio do Governo e Regulamentações

\begin{tabular}{|c|c|c|}
\hline Fatores & Produtores de Grande Porte & Produtores de Pequeno Porte \\
\hline $\begin{array}{l}\text { Apoio do Governo e } \\
\text { Regulamentações }\end{array}$ & 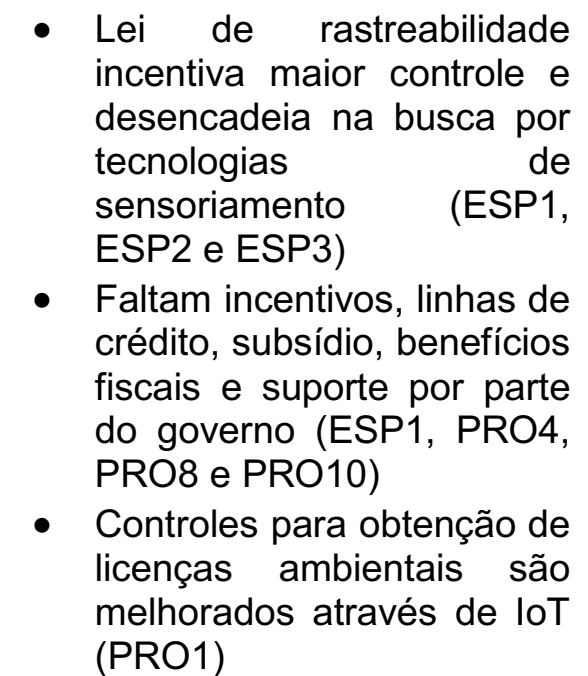 & $\begin{array}{l}\text { - Exigência por rastreabilidade } \\
\text { fez com que os pequenos } \\
\text { produtores saissem da zona } \\
\text { de conforto e iniciassem uma } \\
\text { profissionalização do plantio } \\
\text { (FOR3, ESP3, PRO2) } \\
\text { - Faltam incentivos, linhas de } \\
\text { crédito, subsídio, benefícios } \\
\text { fiscais e suporte por parte do } \\
\text { governo (ESP1, PRO4, PRO8 } \\
\text { e PRO10) }\end{array}$ \\
\hline
\end{tabular}

Fonte: Autor

Referente as regulamentações, entende-se que a lei de rastreabilidade é um fator importante para os pequenos produtores, pois exige maior profissionalização do plantio e do pós-colheita, indiretamente levando os produtores a buscar melhores práticas, com ou sem tecnologia. As demandas de rastreabilidade já haviam sido absorvidas pelos grandes produtores, por conta das exigências dos seus clientes. Os pequenos produtores iniciaram o processo de rastreio com pouca informação sobre o assunto e com menor visibilidade sobre os benefícios. Entende-se que as leis e o apoio do governo podem influenciar a adoção de internet of things, porém não são decisivos, pois os produtores que já utilizam a tecnologia não consideraram estes fatores no momento da adoção. A alavancagem do uso de loT pode ser realizado por instituições responsáveis pelo direcionamento do pequeno produtor, como cooperativas e sindicatos, com ou sem apoio do governo.

No Quadro 44 encontra-se a composição final do fator ambiental. 
Quadro 44 - Resultados - Fator Ambiental

\begin{tabular}{|c|c|c|}
\hline Grande Produtor & $\begin{array}{c}\text { Impacto na } \\
\text { Adoção }\end{array}$ & Como? \\
\hline Pressão Competitiva & SIM & $\begin{array}{c}\text { A busca pelas melhores práticas devido a } \\
\text { exigência do mercado incentiva a utilização } \\
\text { de internet of things }\end{array}$ \\
\hline $\begin{array}{c}\text { Apoio do Governo e } \\
\text { Regulamentações }\end{array}$ & NÃO & $\begin{array}{c}\text { As exigências regulatórias são previamente } \\
\text { supridas e o apoio do governo não é um fator } \\
\text { decisivo }\end{array}$ \\
\hline Pequeno Produtor & $\begin{array}{c}\text { Impacto na } \\
\text { Adoção }\end{array}$ & $\begin{array}{c}\text { Como? } \\
\text { Pressão Competitiva }\end{array}$ \\
\hline SIM & $\begin{array}{c}\text { As vendas através de atravessadores } \\
\text { desincentiva a busca por melhores práticas } \\
\text { no plantio }\end{array}$ \\
\hline $\begin{array}{c}\text { Apoio do Governo e } \\
\text { Regulamentações }\end{array}$ & SIM & $\begin{array}{c}\text { As exigências regulatórias incentivam a } \\
\text { busca por melhores práticas e a falta de } \\
\text { apoio do governo desacelera o incentivo a } \\
\text { adoção de Internet of Things }\end{array}$ \\
\hline
\end{tabular}

Fonte: Autor

\subsection{REVISÃO QUADRO TEÓRICO}

Após a discussão dos resultados dos quatro fatores abordados no quadro teórico, os construtos apresentaram a seguinte distribuição de impacto na adoção de internet of things, conforme o Quadro 45.

Quadro 45 - Revisão Quadro Teórico

\begin{tabular}{|c|c|c|c|}
\hline \multirow{2}{*}{\multicolumn{2}{|c|}{ Fatores }} & \multicolumn{2}{|c|}{ Impacto na Adoção de loT } \\
\hline & & \multirow{2}{*}{$\frac{\text { Pequeno Porte }}{\text { SIM }}$} & \multirow{2}{*}{$\begin{array}{c}\text { Grande Porte } \\
\text { SIM }\end{array}$} \\
\hline \multirow{4}{*}{ Comportamental } & $\begin{array}{l}\text { Expectativa de } \\
\text { Perfomance }\end{array}$ & & \\
\hline & Complexidade & SIM & SIM \\
\hline & Influência Social & SIM & $\mathrm{NÃO}$ \\
\hline & $\begin{array}{c}\text { Condições } \\
\text { Facilitadoras }\end{array}$ & NÃO & NÃO \\
\hline \multirow{2}{*}{ Tecnológico } & Custo & SIM & SIM \\
\hline & Disponibilidade & $\mathrm{NÃO}$ & NÃO \\
\hline Organizacional & $\begin{array}{c}\text { Tamanho e Estrutura } \\
\text { da Empresa }\end{array}$ & SIM & SIM \\
\hline Ambiental & Pressão Competitiva & SIM & SIM \\
\hline
\end{tabular}


\begin{tabular}{|l|c|c|c|} 
& $\begin{array}{c}\text { Apoio do Governo e } \\
\text { Regulamentações }\end{array}$ & NÃO & SIM \\
\hline
\end{tabular}

Fonte: Autor

No Quadro 45, verifica-se que o quadro teórico necessitou ser avaliado conforme os diferentes portes das empresas, evidenciando que o fator organizacional influencia diretamente nas questões comportamentais dos produtores. O tamanho e estrutura da empresa divergiram as opiniões dos produtores em todos os construtos, fazendo com que os insights sobre a adoção fossem diferentes, mesmo que para o mesmo segmento. Como exemplo, a influência social é importante para os grandes produtores, uma vez que possuem stakeholders que os direcionam ao uso de internet of things, enquanto os pequenos produtores não sentem a influência por parte de seus pares e parceiros. Os únicos construtos que foram negados os impactos na adoção de internet of things foram as condições facilitadores e disponibilidade. Primeiramente no que tange as condições facilitadoras, as tecnologias e práticas para adoção de internet of things contornam possíveis problemas que estão a vista dos produtores, como a conexão remota, clima e terrenos acidentados. Referente a disponibilidade, a prontidão tecnológica não é um fator limitante a adoção, apesar dos produtores solicitarem adaptações voltadas para hortaliças.

Por fim, entende-se que os pequenos produtores apresentam maior defasagem informacional e menor poder de investimento, fatores que distanciam a implementação de internet of things no curto prazo. Os grandes produtores, já alavancados pelos seus parceiros comerciais, tem acesso mais rápido e viável as tecnologias, aumentando o controle sobre o plantio e obtendo maior produtividade. 


\section{CONCLUSÃO}

O presente estudo buscou identificar como a adoção de internet of things no setor de hortaliças é impactada por fatores tecnológicos, organizacionais, ambientais e comportamentais. Através da teoria analisada, elaborou-se um modelo teórico que direcionou a coleta de informações com 15 produtores, 3 especialistas e 4 fornecedores de hortaliças.

Com base nos resultados apresentados, o fator tecnológico impacta a adoção de internet of things com o custo de implementação, em que os produtores se deparam questões de planejamento e avaliação de retorno investimento. No fator organizacional, verificou-se que empresas mais estruturadas têm maior capacidade de avaliar, planejar e, consequentemente, adotar a tecnologia. $\mathrm{O}$ fator ambiental impacta principalmente sob as exigências de mercado, por parte de grandes varejistas e dos consumidores finais, que buscam maior qualificação e rastreio dos produtos, desencadeando na adoção de Internet of Things por parte dos produtores que se adequam às melhores práticas do plantio. Por fim, o fator comportamental impacta a decisão sobre o uso de loT com base na percepção do usuário referente a melhoria nos seus processos internos, com o apoio de profissionais especializados em tecnologia e na aceitação das tendências de mercado oriundas da influência social.

Observa-se que o fator organizacional é decisivo na adoção de internet of things, pois dos casos estudados, apenas grandes produtores implementaram a tecnologia. A maior defasagem ocorre na gestão do negócio e no poder investimento. Para solucionar a defasagem entre pequenos e grandes produtores, algumas sugestões são maior aporte do governo com subsídios, isenções fiscais e crédito, além do apoio informacional de instituições como cooperativas e sindicatos.

Para pesquisas futuras, sugere-se a aplicação de métodos quantitativos para confirmar as conclusões deste estudo, junto à aplicação de outros modelos de adoção de tecnologia, além do entendimento da adoção de internet of things no plantio de outras culturas e nos demais elos da cadeia de suprimentos agrícola. 


\section{REFERÊNCIAS}

AHMED, Nurzaman; DE, Debashis; HUSSAIN, Iftekhar. Internet of Things (IoT) for Smart Precision Agriculture and Farming in Rural Areas. leee Internet Of Things Journal, [s.I.], v. 5, n. 6, p.4890-4899, dez. 2018. Institute of Electrical and Electronics Engineers (IEEE). http://dx.doi.org/10.1109/jiot.2018.2879579.

AJZEN, Icek; FISHBEIN, Martin. Understanding attitudes and predicting social behavior. Michigan: Prentice-hall, 1980. $278 p$

ALHOGAIL, Areej. Improving IoT Technology Adoption through Improving Consumer Trust. Mdpi Technologies. Riyadh, p. 1-17. 7 jul. 2018

ALIEV, Khurshid et al. Internet of Plants Application for Smart Agriculture. ljacsa. p. 421-430. abr. 2018

AROOJ, Maha; ASIF, Muhammad; SHAH, Syed Zeeshan. Modeling Smart Agriculture using SensorML. ljacsa. Pakpattan, p. 511-517. jan. 2017.

ATZORI, Luigi; IERA, Antonio; MORABITO, Giacomo. The Internet of Things: A survey. Computer Networks, [s.I.], v. 54, n. 15, p.2787-2805, out. 2010. Elsevier BV. http://dx.doi.org/10.1016/j.comnet.2010.05.010.

AWA, Hart O.; UKOHA, Ojiabo; EMECHETA, Batholomew C.. Integrating TAM and TOE Frameworks and Expanding their Characteristic Constructs for ECommerce Adoption by SMEs. Port Harcourt: Informing Science \& It Education Conference (insite) 2012, 2012.

BAKER, Jeff. The Technology-Organization-Environment Framework. Information Systems Theory, [s.l.], p. 231-245, 1 ago. 2011. Springer New York. http://dx.doi.org/10.1007/978-1-4419-6108-2_12.

BHAGWAT, Pravin; RAMAN, Bhaskaran; SANGHI, Dheeraj. Turning 802.11 InsideOu. Acm Sigcomm Computer Communications Review, X, v. 34, n. 1, p.33-38, jan. 2004.

BOTTA, Alessio et al. On the Integration of Cloud Computing and Internet of Things. 2014 International Conference on Future Internet Of Things And Cloud, [s.I.], ago. 2014. IEEE. http://dx.doi.org/10.1109/ficloud.2014.14.

CAMBRA, Carlos et al. Smart System for Bicarbonate Control in Irrigation for Hydroponic Precision Farming. Sensors, [s.I.], v. 18, n. 5, p.1333-1340, 25 abr. 2018. MDPI AG. http://dx.doi.org/10.3390/s18051333.

CARCARY, Marian; MACCANI, Giovanni; DOHERTY, Eileen; CONWAY, Gerard. Exploring the Determinants of loT Adoption: findings from a systematic literature review. : Findings from a Systematic Literature Review. Lecture Notes In Business Information Processing, [s.I.], p. 113-125, 2018. Springer International Publishing. http://dx.doi.org/10.1007/978-3-319-99951-7_8.

CAUCHICK, Paulo Augusto et al. Metodologia de Pesquisa em Engenharia de Produção e Gestão de Operações. 7. ed. atual. Rio de Janeiro: Elsevier, 2010. 226 p. v. 1. ISBN 978-85-352-3523-4. 
CEAGESP - CENTRO DE QUALIDADE EM HORTICULTURA. Manuseio Mínimo. São Paulo: CEAGESP-CQH, 2009, 12 p. (Circular Técnica CEAGESP-CQH, n.17)

CEAGESP. Rastreabilidade. $2019 . \quad$ Disponível em: http://www.ceagesp.gov.br/entrepostos/servicos/rastreabilidade/. Acesso em: 18 jan. 2020.

CEAGESP. Chefe Seção Ceagesp. 2020. Disponível em: http://www.ceagesp.gov.br/wp-content/uploads/2020/10/RELA\%C3\%87\%C3\%83ODE-EMPREGADOS.pdf. Acesso em: 10 out. 2020.

CERVO, Amado L.; BERVIAN, Pedro A.; SILVA, Roberto da. Metodologia Científica. 6. ed. atual. São Paulo: Pearson, 2006. 162 p. v. 1. ISBN 85-7605-047-1.

CHOUDRIE, J., \& DWIVEDI, Y. K. (2005). Investigating the research approaches for examining technology adoption issues. Journal of Research Practice, 1(1), Article D1. Retrieved [Date of Access], from http://jrp.icaap.org/index.php/jrp/article/view/4/

COLLINS, A.; FAUSER, C. J. M. B.. Balacing the strengths of systematic and narrative reviews. p. 103-104. 2005

CONAB. Boletim Hortigranjeiro. Brasília: -, v. 5, n. 10, 01 out. 2019a. Mensal. Issn 2446-5860.

CONAB. PROHORT - SIMAB. 2019b. Disponível em: <http://dw.ceasa.gov.br/>. Acesso em: 23 dez. 2019.

DAVIS, Fred D.; BAGOZZI, Richard P.; WARSHAW, Paul R.. User Acceptance of Computer Technology: A Comparison of Two Theoretical Models. Management Science, California, v. 8, n. 35, p.982-1004, ago. 1989

DIFALLAH, Wafa et al. Intelligent Irrigation Management System. ljacsa. Bechar, p. 429-434. jan. 2018

DOBRESCU, Radu; MEREZEANU, Daniel; MOCANU, Stefan. Context-aware control and monitoring system with IOT and cloud support. Computers And Electronics In Agriculture, [s.I.], v. 160, p.91-99, maio 2019. Elsevier BV. http://dx.doi.org/10.1016/j.compag.2019.03.005

EMBRAPA. Como Plantar Hortaliças. Brasíia: Cw Produções Ltda., v. 1, 01 jan. 2006. Mensal. Isbn 85-7383-340-8.

EMBRAPA. Pós-colheita de hortaliças: o produtor pergunta, a Embrapa responde. Brasília: Embrapa Informação Tecnológica, 1 jan. 2011. Isbn 978-85-7383522-9.

EMBRAPA. Ministério da Agricultura. EMBRAPA em números. Brasília: Embrapa, 2018.

EMBRAPA. A Cultura da Batata: adubação. Adubação. 2019. Disponível em: https://www.embrapa.br/hortalicas/batata/adubacao. Acesso em: 10 nov. 2019.

EMBRAPA. Colaboradores. 2020. Disponível em: https://www.embrapa.br/equipe/lempregado/. Acesso em: 10 out. 2020. 
ETRIYA, Etriya et al. The importance of innovation adoption and generation in linking entrepreneurial orientation with product innovation and farm revenues: the case of vegetable farmers in west java, indonesia. International Food And Agribusiness Management Review, [S.L.], v. 21, n. 7, p. 969-988, 18 set. 2018. Wageningen Academic Publishers. http://dx.doi.org/10.22434/ifamr2017.0038.

FAROOQ, M U et al. A Critical Analysis on the Security Concerns of Internet of Things. International Journal Of Computer Applications. Sadia Mazhar, p. 1-6. 18 fev. 2015.

FAO. Global food losses and food waste. Dusseldorf: 2011.

FERRÁNDEZ-PASTOR, Francisco et al. Developing Ubiquitous Sensor Network Platform Using Internet of Things: Application in Precision Agriculture. Sensors, [s.l.], v. 16, n. 7, p.1141-1145, 22 jul. 2016. MDPI AG. http://dx.doi.org/10.3390/s16071141.

FERRÁNDEZ-PASTOR, Francisco et al. Precision Agriculture Design Method Using a Distributed Computing Architecture on Internet of Things Context. Sensors, [s.I.], v. 18, n. 6, p.1731-1736, 28 maio 2018. MDPI AG. http://dx.doi.org/10.3390/s18061731

FIGUEROA; POPE. Root System Water Consumption Pattern Identification on Time Series Data. Sensors, [s.I.], v. 17, n. 6, p.1410-1415, 16 jun. 2017. MDPI AG. http://dx.doi.org/10.3390/s17061410.

GENG, Liwei; DONG, Tingting. An Agricultural Monitoring System Based on Wireless Sensor and Depth Learning Algorithm. International Journal Of Online Engineering (ijoe), [s.I.], v. 13, n. 12, p.127-135, 11 dez. 2017. International Association of Online Engineering (IAOE). http://dx.doi.org/10.3991/ijoe.v13i12.7885

GIL, Antonio Carlos. Como Elaborar Projetos de Pesquisa. 4. ed. atual. São Paulo: Atlas, 2002. 175 p. v. 1. ISBN 85-224-3169-8.

GIUSTO, Daniel et al. The Internet of Things. Springer, 2010.

GOAP, Amarendra et al. An loT based smart irrigation management system using Machine learning and open source technologies. Computers And Electronics In Agriculture, [s.I.], v. 155, p.41-49, dez. 2018. Elsevier BV. http://dx.doi.org/10.1016/j.compag.2018.09.040.

GONDCHAWAR, Nikesh; KAWITKAR, R. S.. IoT based Smart Agriculture. Ijarcce, X, v. 5, n. 6, p.838-842, jun. 2016.

GONZALEZ-AMARILLO, Carlos Andres et al. An loT-Based Traceability System for Greenhouse Seedling Crops. leee Access, [s.I.], v. 6, p.67528-67535, 2018. Institute of Electrical and Electronics Engineers (IEEE). http://dx.doi.org/10.1109/access.2018.2877293.

GUBBI, Jayavardhana et al. Internet of Things (IOT): A vision, architectural elements, and future directions. Future Generation Computer Systems, [s.I.], v. 29, n. 7, p.1645-1660, set. 2013. Elsevier BV. http://dx.doi.org/10.1016/j.future.2013.01.010. 
GUTIERREZ, Anabel; BOUKRAMI, Elias; LUMSDEN, Ranald. Technological, organisational and environmental factors influencing managers' decision to adopt cloud computing in the UK. Journal Of Enterprise Information Management, [s.l.], v. 28, n. 6, p.788-807, 12 out. 2015. Emerald. http://dx.doi.org/10.1108/jeim-012015-0001.

HART, Chris. Doing a Literature Review: releasing the social science research imagination. Los Angeles/ London/ New Delhi / Washington: Sage Publications Ltd, 1998. 228 p. ISBN 978-7619-5974-8.

HUSSAIN, Md. Iftekhar et al. An Efficient TDMA MAC Protocol for Multi-hop WiFiBased Long Distance Networks. Wireless Personal Communications, [s.I.], v. 86, n. 4, p.1971-1994, 8 jan. 2016. Springer Science and Business Media LLC. http://dx.doi.org/10.1007/s11277-015-3165-9

ISLA. Tomate IPA6. 2019. Disponível em: https://isla.com.br/arquivos-paradownload/. Acesso em: 19 nov. 2019.

JANG, Seung-hwan; YU, Chang Ho. A Study on Internet of Things (IoT): Users' Reuse Intention Using Technology Acceptance Model in Korea. International Journal Of Business And Management Science, Pusan, v. 2, n. 7, p. 279-295, 01 jan. 2017.

JAYARAMAN, Prem et al. Internet of Things Platform for Smart Farming: Experiences and Lessons Learnt. Sensors, [s.I.], v. 16, n. 11, p.1884-1889, 9 nov. 2016. MDPI AG. http://dx.doi.org/10.3390/s16111884.

JEPPESEN, Jacob Høxbroe et al. Open geospatial infrastructure for data management and analytics in interdisciplinary research. Computers And Electronics In Agriculture, [s.I.], v. 145, p.130-141, fev. 2018. Elsevier BV. http://dx.doi.org/10.1016/j.compag.2017.12.026.

JINBO, Chen; YU, Zhong; LAM, Anthony. Research on Monitoring Platform of Agricultural Product Circulation Efficiency Supported by Cloud Computing. Wireless Personal Communications, [s.I.], v. 102, n. 4, p.3573-3587, 23 fev. 2018. Springer Nature. http://dx.doi.org/10.1007/s11277-018-5392-3

KALOXYLOS, Alexandros et al. Farm management systems and the Future Internet era. Computers And Electronics In Agriculture, [s.I.], v. 89, p.130-144, nov. 2012. Elsevier BV. http://dx.doi.org/10.1016/j.compag.2012.09.002.

KAMATH, Radhika; BALACHANDRA, Mamatha; PRABHU, Srikanth. Raspberry Pi as Visual Sensor Nodes in Precision Agriculture: A Study. leee Access, [s.I.], v. 7, p.45110-45122, 2019. Institute of Electrical and Electronics Engineers (IEEE). http://dx.doi.org/10.1109/access.2019.2908846.

KAMIENSKI, Carlos et al. Smart Water Management Platform: IoT-Based Precision Irrigation for Agriculture. Sensors, [s.I.], v. 19, n. 2, p.276-281, 11 jan. 2019. MDPI AG. http://dx.doi.org/10.3390/s19020276

KETOKIV, Mikko; CHOI, Thomas. Renaissance of case research as a scientific method. Journal of Operations Management, Madrid, ano 2014, v. 1, n. 1, p. 232-240, 24 mar. 2014 
KIANI, Farzad; SEYYEDABBASI, Amir. Wireless Sensor Network and Internet of Things in Precision Agricultur. ljacsa. Istanbul, p. 99-104. jun. 2018.

KIM, Sehan; LEE, Meonghun; SHIN, Changsun. IoT-Based Strawberry Disease Prediction System for Smart Farming. Sensors, [s.I.], v. 18, n. 11, p.4051-4056, 20 nov. 2018. MDPI AG. http://dx.doi.org/10.3390/s18114051

KONTOGIANNIS, Sotirios et al. Proposed Fuzzy-NN Algorithm with LoRaCommunication Protocol for Clustered Irrigation Systems. Future Internet, [s.I.], v. 9, n. 4, p.78-82, 7 nov. 2017. MDPI AG. http://dx.doi.org/10.3390/fi9040078

$\mathrm{LI}$, Juanjuan. Design and Realization of Greenhouse Sensor Intelligent Management System Based on Internet of Things. International Journal Of Online Engineering (ijoe), [s.I.], v. 13, n. 05, p.80-90, 14 maio 2017. International Association of Online Engineering (IAOE). http://dx.doi.org/10.3991/ijoe.v13i05.7051

LIN, Angela; CHEN, Nan-chou. Cloud computing as an innovation: Percepetion, attitude, and adoption. International Journal Of Information Management, [s.I.], v. 32, n. 6, p.533-540, dez. 2012. Elsevier BV. http://dx.doi.org/10.1016/j.ijinfomgt.2012.04.001.

LIN, Danping; LEE, C. K. M.; LIN, Kangwei. Research on Effect Factors Evaluation of Internet of Things (IOT) Adoption in Chinese Agricultural Supply Chain. IEEE IEEM. Shanghai, p. 612-615. jan. 2016.

LIN, Hanhui et al. The Construction of a Precise Agricultural Information System Based on Internet of Things. International Journal Of Online Engineering (ijoe), [s.I.], v. 11, n. 6, p.10-15, 5 nov. 2015. International Association of Online Engineering (IAOE). http://dx.doi.org/10.3991/ijoe.v11i6.4847

LIU, Shubo et al. Internet of Things Monitoring System of Modern Eco-Agriculture Based on Cloud Computing. leee Access, [s.I.], v. 7, p.37050-37058, 2019. Institute of Electrical and Electronics Engineers (IEEE). http://dx.doi.org/10.1109/access.2019.2903720.

LOPES, Ana Paula Vilas Boas Viveiros. REVISÃO SISTEMÁTICA DE LITERATURA NA ÁREA DE SISTEMAS DE INFORMAÇÃO. In: ENEGEP 2018, 38., 2018, São Paulo. "A Engenharia de Produção e suas contribuições para o desenvolvimento do Brasil". Maceió: -, 2018. p. 1-22.

MARTÍNEZ, Ramón et al. A Testbed to Evaluate the FIWARE-Based loT Platform in the Domain of Precision Agriculture. Sensors, [s.I.], v. 16, n. 11, p.1979-1986, 23 nov. 2016. MDPI AG. http://dx.doi.org/10.3390/s16111979.

MASOOD, Tariq; EGGER, Johannes. Augmented reality in support of Industry 4.0-Implementation challenges and success factors. Robotics And Computerintegrated Manufacturing, [s.I.], v. 58, p.181-195, ago. 2019. Elsevier BV. http://dx.doi.org/10.1016/j.rcim.2019.02.003

MASSRUHÁ, Silvia Maria Fonseca Silveira. TECNOLOGIAS DA INFORMAÇÃO E DA COMUNICAÇÃO O PAPEL NA AGRICULTURA: Embrapa, 2015. 3 p. 
MASSRUHÁ, Silvia Maria Fonseca Silveira; LEITE, Maria Angelica de Andrade. Agro 4.0: Rumo à agricultura digital. JC na Escola Ciência, Tecnologia e Sociedade: Mobilizar o Conhecimento para alimentar o Brasil, Brasília, p.28-35, fev. 2017.

MATTEI, Lauro. Emprego agrícola: cenários e tendências. Estudos Avançados, p.35-52, jan. 2015.

MAZON-OLIVO, Bertha et al. Rules engine and complex event processor in the context of internet of things for precision agriculture. Computers And Electronics In Agriculture, [s.l.], v. 154, p.347-360, nov. 2018. Elsevier BV. http://dx.doi.org/10.1016/j.compag.2018.09.013

MEKALA, Mahammad Shareef; VISWANATHAN, P.. A Survey: Smart Agriculture IoT with Cloud Computing. leee. Vellore, 2017

MIN, Xiaobo; KUANG, Weihong. Study on the Ecological Farming Control System Based on the Internet of Things. Wireless Personal Communications, [s.l.], v. 102, n. 4, p.2955-2967, 19 jan. 2018. Springer Nature. http://dx.doi.org/10.1007/s11277018-5318-0.

MOHANRAJ, I.; ASHOKUMAR, Kirthika; NAREN, J.. Field Monitoring and Automation Using IOT in Agriculture Domain. Procedia Computer Science, [s.I.], v. 93, p.931-939, 2016. Elsevier BV. http://dx.doi.org/10.1016/j.procs.2016.07.275

MOON, Aekyeung et al. Evaluating fidelity of lossy compression on spatiotemporal data from an loT enabled smart farm. Computers And Electronics In Agriculture, [s.I.], v. 154, p.304-313, nov. 2018. Elsevier BV. http://dx.doi.org/10.1016/j.compag.2018.08.045.

MUANGPRATHUB, Jirapond et al. IoT and agriculture data analysis for smart farm. Computers And Electronics In Agriculture, [s.l.], v. 156, p.467-474, jan. 2019. Elsevier BV. http://dx.doi.org/10.1016/j.compag.2018.12.011.

NAMISIKO, Peter; MUNIALO, Catherine; NYONGESA, Stephen. Towards an Optimization Framework for E-Learning in Developing Countries: A Case of Private Universities in Kenya. Journal Of Computer Science And Information Technology, Kenya, v. 2, n. 2, p. 131-148, 01 jun. 2014. ISSN: 2334-2366.

NANDHINI, S. Aasha et al. Web Enabled Plant Disease Detection System for Agricultural Applications Using WMSN. Wireless Personal Communications, [s.I.], v. 102, n. 2, p.725-740, 4 dez. 2017. Springer Nature. http://dx.doi.org/10.1007/s11277-017-5092-4.

NAYYAR, Anand; PURI, Vikram. Smart farming. Communication And Computing Systems, [s.I.], 9 nov. 2016. CRC Press. http://dx.doi.org/10.1201/9781315364094121

OJHA, Tamoghna; MISRA, Sudip; RAGHUWANSHI, Narendra Singh. Wireless sensor networks for agriculture: The state-of-the-art in practice and future challenges. Computers And Electronics In Agriculture, [s.I.], v. 118, p.66-84, out. 2015. Elsevier BV. http://dx.doi.org/10.1016/j.compag.2015.08.011. 
OLIVEIRA, Tiago; MARTINS, Maria Fraga. Literature Review of Information Technology Adoption Models at Firm Level. The Electronic Journal Information Systems Evaluation, -, v. 1, n. 14, p. 110-121, 01 jan. 2011. ISSN 1566-6379.

PANDURU, Krishna et al. Internet of Things: A review from "Farm to Fork". Imar Technology Gateway. Kerry. 2019.

RAY, Partha Pratim. Internet of things for smart agriculture: Technologies, practices and future direction. Journal Of Ambient Intelligence And Smart Environments. Sikkim, p. 395-420. jan. 2017.

ROGERS, Everett M.. Diffusion of Innovations. 2. ed. New York: The American Center Library, 1995. 236 p.

SARANGI, Sanat; UMADIKAR, Jayalakshmi; KAR, Subrat. Automation of Agriculture Support Systems using Wisekar: Case study of a crop-disease advisory service. Computers And Electronics In Agriculture, [s.I.], v. 122, p.200-210, mar. 2016. Elsevier BV. http://dx.doi.org/10.1016/j.compag.2016.01.009.

SAWANT, Suryakant; DURBHA, Surya S.; JAGARLAPUDI, Adinarayana. Interoperable agro-meteorological observation and analysis platform for precision agriculture: A case study in citrus crop water requirement estimation. Computers And Electronics In Agriculture, [s.I.], v. 138, p.175-187, jun. 2017. Elsevier BV. http://dx.doi.org/10.1016/j.compag.2017.04.019.

SEBRAE. Perfil do Produtor Rural. Brasília: Sebrae, 2012. 44 p.

SEMERARO, Teodoro et al. Modelling fuzzy combination of remote sensing vegetation index for durum wheat crop analysis. Computers And Electronics In Agriculture, [s.I.], v. 156, p.684-692, jan. 2019. Elsevier BV. http://dx.doi.org/10.1016/j.compag.2018.12.027.

SHAHZADI, Raheela et al. Internet of Things based Expert System for Smart Agriculture. International Journal Of Advanced Computer Science And Applications. Sahiwal, p. 341-350. jan. 2016.

SOUZA FILHO, Hildo Meirelles de et al. CONDITIONANT FACTORS OF ADOPTION OF TECHNOLOGICAL INNOVATIONS IN AGRICULTURE. Cadernos de Ciência \& Tecnologia, Brasilia, v. 28, p.223-255, abr. 2011.

SUN, Shiwei; CEGIELSKI, Casey G.; JIA, Lin; HALL, Dianne J.. Understanding the Factors Affecting the Organizational Adoption of Big Data. Journal Of Computer Information Systems, [s.I.], v. 58, n. 3, p. 193-203, 7 out. 2016. Informa UK Limited. http://dx.doi.org/10.1080/08874417.2016.1222891.

TANG, Dongping; CHEN, Lianjin. A Review of the Evolution of Research on Information Technology Acceptance Model. leee. Guangzhou, p. 588-591. jan. 2011.

TORNATZKY, L. G.; FLEISCHER, M.. Technological Innovation as a Process. The Processes Of Technological Innovation. p. 27-50. jan. 1990.

TOUSEAU, Lionel; SOMMER, Nicolas. Contribution of the Web of Things and of the Opportunistic Computing to the Smart Agriculture: A Practical Experiment. 
Future Internet [s.I.], v. 11, n. 2, p.33-37, 1 fev. 2019. MDPI AG. http://dx.doi.org/10.3390/fi11020033

UDDIN, Mohammad Ammad et al. UAV-Assisted Dynamic Clustering of Wireless Sensor Networks for Crop Health Monitoring. Sensors, [s.I.], v. 18, n. 2, p.555-565, 11 fev. 2018. MDPI AG. http://dx.doi.org/10.3390/s18020555.

VENKATESH, Viswanath; DAVIS, Fred D.. A Theoretical Extension of the Technology Acceptance Model: Four Longitudinal Field Studies. Management Science, [s.I.], v. 46, n. 2, p.186-204, fev. 2000. Institute for Operations Research and the Management http://dx.doi.org/10.1287/mnsc.46.2.186.11926 Sciences

(INFORMS).

VENKATESH, Viswanath et al. USER ACCEPTANCE OF INFORMATION TECHNOLOGY: TOWARD A UNIFIED VIEW. Management Information Systems Research Center, Minnesota, v. 27, n. 3, p. 425-478, 01 set. 2003.

VENKATESH; THONG. Consumer Acceptance and Use of Information Technology: Extending the Unified Theory of Acceptance and Use of Technology. Mis Quarterly, [s.I.], v. 36, n. 1, p.157-169, 2012. JSTOR. http://dx.doi.org/10.2307/41410412.

WEI, Jin; LV, Shuangqing. Research on the Distribution System of Agricultural Products Cold Chain Logistics Based on Internet of Things. lop Conference Series: Earth and Environmental Science, [s.I.], v. 237, 19 mar. 2019. IOP Publishing. http://dx.doi.org/10.1088/1755-1315/237/5/052036

XIAN, Kehua. Internet of Things Online Monitoring System Based on Cloud Computing. International Journal Of Online Engineering (ijoe), [s.I.], v. 13, n. 09, p.123-128, 22 set. 2017. International Association of Online Engineering (IAOE). http://dx.doi.org/10.3991/ijoe.v13i09.7591.

XU, Jinying; LU, Weisheng. Smart Construction from Head to Toe: A Closed-Loop Lifecycle Management System Based on IoT. Construction Research Congress 2018, [s.l.], 29 mar. 2018. American Society of Civil Engineers. http://dx.doi.org/10.1061/9780784481264.016.

YIN, Robert K.. Case Study Research: design and methods. Thousand Oaks, California: Sage Publications, 2014.

ZHANG, Xueyan et al. Monitoring Citrus Soil Moisture and Nutrients Using an loT Based System. Sensors, [s.I.], v. 17, n. 3, p.447-450, 23 fev. 2017. MDPI AG. http://dx.doi.org/10.3390/s17030447

ZHAO, Wei; WANG, Chaowei; NAKAHIRA, Yorie. MEDICAL APPLICATION ON INTERNET OF THINGS. In: ICCTA2011, -., 2011, Tokyo e Beijing. -. Tokyo e Beijing: -, 2011. p. 1-6.

ZHENG, Yang-yang et al. CropDeep: The Crop Vision Dataset for Deep-LearningBased Classification and Detection in Precision Agriculture. Sensors, [s.I.], v. 19, n. 5, p.1058-1062, 1 mar. 2019. MDPI AG. http://dx.doi.org/10.3390/s19051058 


\section{APÊNDICE - A - TABELA DE ARTIGOS}

\begin{tabular}{|c|c|c|c|}
\hline NOME_ARQUIVO & CATEGORIA & MÉTODO & TERMOS \\
\hline Aliev et al. (2018) & SENSORES & Experimento & WSN \\
\hline Arooj, Asif e Shah (2017) & SENSORES & $\begin{array}{l}\text { Estudo de } \\
\text { caso }\end{array}$ & WSN \\
\hline Cambra et al. (2018) & SENSORES & Experimento & WSN \\
\hline Difallah et al. (2018) & IRRIGAÇÃO & $\begin{array}{l}\text { Estudo de } \\
\text { caso }\end{array}$ & System \\
\hline $\begin{array}{l}\text { Dobrescu, Merezeanu e Mocanu } \\
\text { (2019) }\end{array}$ & SISTEMA & $\begin{array}{l}\text { Estudo de } \\
\text { caso }\end{array}$ & $\begin{array}{l}\text { Cloud Computing } \\
\text { Precion }\end{array}$ \\
\hline Ferrández-Pastor et al. (2016) & SENSORES & $\begin{array}{l}\text { Experimento } \\
\text { Estudo de }\end{array}$ & $\begin{array}{l}\text { Agriculture } \\
\text { Precision }\end{array}$ \\
\hline Ferrández-Pastor et al. (2018) & OPERAÇÃO & caso & Agriculture \\
\hline Figueroa e Pope (2017) & IRRIGAÇÃO & Experimento & System \\
\hline Geng e Dong (2017) & SENSORES & Experimento & WSN \\
\hline Goap et al. (2018) & IRRIGAÇÃO & Experimento & System \\
\hline Gonzalez-Amarillo et al. (2018) & SISTEMA & Experimento & System \\
\hline Jayaraman et al. (2016) & SISTEMA & $\begin{array}{l}\text { Experimento } \\
\text { Estudo de }\end{array}$ & System \\
\hline Jeppesen et al. (2018) & SISTEMA & caso & System \\
\hline Jinbo e Lam (2018) & SISTEMA & $\begin{array}{l}\text { Experimento } \\
\text { Estudo de }\end{array}$ & Video Data \\
\hline Kaloxylos et al. (2012) & OPERAÇÃO & caso & System \\
\hline $\begin{array}{l}\text { Kamath, Balachandra e Prabhu } \\
\text { (2019) }\end{array}$ & SENSORES & $\begin{array}{l}\text { Experimento } \\
\text { Estudo de }\end{array}$ & $\begin{array}{l}\text { Video Data } \\
\text { Precision }\end{array}$ \\
\hline Kamienski et al. (2019) & SISTEMA & caso & Agriculture \\
\hline Kiani e Seyyedabbasi (2018) & SISTEMA & Experimento & WSN \\
\hline Kim, Lee e Shin (2018) & SISTEMA & Experimento & System \\
\hline Kontogiannis et al. (2017) & IRRIGAÇÃO & Experimento & System \\
\hline Li (2017) & SISTEMA & Experimento & $\begin{array}{l}\text { System } \\
\text { Precion }\end{array}$ \\
\hline Lin et al. (2015) & SISTEMA & Experimento & Agriculture \\
\hline Liu et al. (2019) & SISTEMA & Experimento & Cloud Computing \\
\hline Martínez et al. (2016) & SENSORES & Experimento & WSN \\
\hline Mauangprathub et al. (2019) & SISTEMA & Experimento & System \\
\hline Mazon-Olivo et al. (2018) & SISTEMA & Experimento & $\begin{array}{l}\text { Precision } \\
\text { Agriculture }\end{array}$ \\
\hline Min e Kuang (2018) & SENSORES & Experimento & System \\
\hline Moon et al. (2018) & SISTEMA & Experimento & System \\
\hline Nandhini et al. (2018) & SISTEMA & Experimento & Video Data \\
\hline Sarangi, Umadikar e Kar (2016) & SISTEMA & $\begin{array}{l}\text { Estudo de } \\
\text { caso }\end{array}$ & System \\
\hline
\end{tabular}


Sawant, Durbha e Adinarayana (2017)

Semeraro et al. (2019)

Shahzadi et al. (2016)

Touseau e Sommer (2019)

Uddin et al. (2018)

Xian (2017)

Zhang et al. (2017)

Zheng et al. (2019)
Estudo de Precision

SENSORES caso Agriculture

SISTEMA Experimento System

SENSORES Experimento WSN

SISTEMA Experimento System

SENSORES Experimento Drone

SISTEMA Experimento

IRRIGAÇÃO Experimento

Cloud Computing

Inteligência

SISTEMA Experimento Video Data 


\section{APÊNCIDE - B - PROTOCOLO DE PESQUISA - PRODUTORES}

1) PREPARAÇÃO PRÉ-ENTREVISTA

Contato com os produtores para compartilhamento do objetivo da pesquisa e autorização para realização da entrevista. Em caso positivo, foi explicado o que é loT e aplicado o roteiro da entrevista.

\section{2) ROTEIRO PARA ENTREVISTA}

\section{Dados Gerais:}

- Data da Visita;

- Nome do Entrevistado;

- Cargo do Entrevistado;

- Idade;

- Tamanho em Faturamento (Micro, Pequena, Média ou Grande Empresa);

- Produtos produzidos;

- Principais clientes;

\section{Breve explicação sobre Internet of Things:}

Internet of Things é a aplicação de sensores e dispositivos que permitem o monitoramento e controle remoto através do uso de internet (ATZORI; IERA; MORABITO, 2010). Na agricultura auxília obter informações sobre o solo, presença de ervas daninhas, temperatura e umidade do ambiente a fim de gerenciar a irrigação, o controle de iluminação e o uso de fertilizantes (FERRÁNDEZ-PASTOR ET AL., 2016).

\section{Perguntas Introdutórias:}

a) Você utiliza alguma tecnologia em seu plantío? Se sim, quais?

b) Você já pensou em utilizar alguma tecnologia no plantío? Se sim, quais? 


\section{Questionário:}

\begin{tabular}{|c|c|c|}
\hline Fatores & Variáveis & Questionamentos \\
\hline \multirow{4}{*}{ Comportamental } & Expectativa de Perfomance & $\begin{array}{l}\text { Você acredita que internet of } \\
\text { things pode agregar qualidade } \\
\text { e aumentar a produtividade no } \\
\text { plantio de hortaliças? Porque? }\end{array}$ \\
\hline & Complexidade & $\begin{array}{c}\text { Você acredita que a } \\
\text { complexidade pode ser uma } \\
\text { barreira a utilização de loT no } \\
\text { plantío de hortaliças? O que } \\
\text { seria complexo? }\end{array}$ \\
\hline & Influência Social & $\begin{array}{c}\text { Você acredita que os } \\
\text { produtores de hortaliças são } \\
\text { influenciados a utilizar loT? Se } \\
\text { sim, por quem? }\end{array}$ \\
\hline & Condições Facilitadoras & $\begin{array}{c}\text { Você acredita que a } \\
\text { infraestrutura de produtores de } \\
\text { hortaliças pode comportar a } \\
\text { utilização de loT? Por que? }\end{array}$ \\
\hline \multirow[t]{2}{*}{ Tecnológico } & Custo & $\begin{array}{l}\text { Você acredita que o custo } \\
\text { pode ser uma barreira para } \\
\text { implementar loT no plantío de } \\
\text { hortaliças? Se sim, pelo preço } \\
\text { dos equipamentos ou pelo seu } \\
\text { poder de investimento atual? }\end{array}$ \\
\hline & Disponibilidade & $\begin{array}{l}\text { Você sabe onde pode contratar } \\
\text { a tecnologia? Acredita que ela } \\
\text { é acessível? }\end{array}$ \\
\hline Organizacional & $\begin{array}{c}\text { Tamanho e Estrutura da } \\
\text { Empresa }\end{array}$ & $\begin{array}{l}\text { Você acredita que pequenos } \\
\text { produtores de hortaliças têm } \\
\text { maiores dificuldades para } \\
\text { adotar loT? Por que? }\end{array}$ \\
\hline \multirow[b]{2}{*}{ Ambiental } & Pressão Competitiva & $\begin{array}{l}\text { Há uma pressão competitiva } \\
\text { entre os produtores de } \\
\text { hortaliças para influenciar a } \\
\text { adoção de loT? Os parceiros } \\
\text { comerciais influenciam os } \\
\text { produtores a adotar loT? }\end{array}$ \\
\hline & $\begin{array}{l}\text { Apoio do Governo e } \\
\text { Reguamentações }\end{array}$ & $\begin{array}{l}\text { Você acredita que o governo } \\
\text { apoia os produtores de } \\
\text { hortaliças a implementar } \\
\text { tecnologias como loT? Se sim, } \\
\text { quais programas? Se não, } \\
\text { como poderia apoiar? Há } \\
\text { regulamentações que te } \\
\text { incentivam a utilizar internet of } \\
\text { things? }\end{array}$ \\
\hline
\end{tabular}




\section{APÊNCIDE - C - PROTOCOLO DE PESQUISA - ESPECIALISTAS E FORNECEDORES}

1) PREPARAÇÃO PRÉ-ENTREVISTA

Contato com os especialistas e fornecedores para compartilhamento do objetivo da pesquisa e autorização para realização da entrevista. Em caso positivo, foi explicado o que é loT e aplicado o roteiro da entrevista.

\section{2) ROTEIRO PARA ENTREVISTA}

\section{Dados Gerais:}

- Data da Visita;

- Nome do Entrevistado;

- Cargo do Entrevistado;

- Idade;

\section{Breve explicação sobre Internet of Things:}

Internet of Things é a aplicação de sensores e dispositivos que permitem o monitoramento e controle remoto através do uso de internet (ATZORI; IERA; MORABITO, 2010). Na agricultura auxília obter informações sobre o solo, presença de ervas daninhas, temperatura e umidade do ambiente a fim de gerenciar a irrigação, o controle de iluminação e o uso de fertilizantes (FERRÁNDEZ-PASTOR ET AL., 2016).

\section{Questionário:}

\begin{tabular}{|c|c|c|}
\hline Fatores & Variáveis & Questionamentos \\
\hline \multirow{4}{*}{ Comportamental } & Expectativa de Perfomance & $\begin{array}{c}\text { Os produtores acreditam que } \\
\text { internet of things pode agregar } \\
\text { qualidade e aumentar a } \\
\text { produtividade no plantio de } \\
\text { hortaliças? Porque? }\end{array}$ \\
\cline { 2 - 3 } & Complexidade & $\begin{array}{c}\text { Os produtores acreditam que a } \\
\text { complexidade pode ser uma } \\
\text { barreira a utilização de loT no }\end{array}$ \\
\hline
\end{tabular}




\begin{tabular}{|c|c|c|}
\hline & & $\begin{array}{l}\text { plantío de hortaliças? O que } \\
\text { seria complexo? }\end{array}$ \\
\hline & Influência Social & $\begin{array}{c}\text { Você acredita que os } \\
\text { produtores de hortaliças são } \\
\text { influenciados a utilizar loT? Se } \\
\text { sim, por quem? }\end{array}$ \\
\hline & Condições Facilitadoras & $\begin{array}{l}\text { Você acredita que a } \\
\text { infraestrutura de produtores de } \\
\text { hortaliças pode comportar a } \\
\text { utilização de loT? Por que? }\end{array}$ \\
\hline \multirow[t]{2}{*}{ Tecnológico } & Custo & $\begin{array}{l}\text { Você acredita que o custo } \\
\text { pode ser uma barreira para } \\
\text { implementar loT no plantío de } \\
\text { hortaliças? Se sim, pelo preço } \\
\text { dos equipamentos ou pelo seu } \\
\text { poder de investimento atual? }\end{array}$ \\
\hline & Disponibilidade & $\begin{array}{l}\text { Os produtores sabem onde } \\
\text { podem contratar a tecnologia? } \\
\text { Acredita que ela é acessível? }\end{array}$ \\
\hline Organizacional & $\begin{array}{c}\text { Tamanho e Estrutura da } \\
\text { Empresa }\end{array}$ & $\begin{array}{l}\text { Você acredita que pequenos } \\
\text { produtores de hortaliças têm } \\
\text { maiores dificuldades para } \\
\text { adotar loT? Por que? }\end{array}$ \\
\hline \multirow[b]{2}{*}{ Ambiental } & Pressão Competitiva & $\begin{array}{l}\text { Há uma pressão competitiva } \\
\text { entre os produtores de } \\
\text { hortaliças para influenciar a } \\
\text { adoção de loT? Os parceiros } \\
\text { comerciais influenciam os } \\
\text { produtores a adotar loT? }\end{array}$ \\
\hline & $\begin{array}{l}\text { Apoio do Governo e } \\
\text { Reguamentações }\end{array}$ & $\begin{array}{l}\text { Você acredita que o governo } \\
\text { apoia os produtores de } \\
\text { hortaliças a implementar } \\
\text { tecnologias como loT? Se sim, } \\
\text { quais programas? Se não, } \\
\text { como poderia apoiar? Há } \\
\text { regulamentações que te } \\
\text { incentivam a utilizar internet of } \\
\text { things? }\end{array}$ \\
\hline
\end{tabular}

Fonte: Autor 